Journal of Fish Biology

March 2017, Volume 90, Issue 3, Pages 653-722

http://dx.doi.org/10.1111/ifb.13197

http://archimer.ifremer.fr/doc/00358/46902/

(c) 2016 Crown copyright. Journal of Fish Biology (c) 2016 The Fisheries

Society of the British Isles

\title{
A review of capture and post-release mortality of elasmobranchs
}

\author{
Ellis J. R. ${ }^{1,{ }^{*}}$, Mccully Phillips S. R. ${ }^{1}$, Poisson Francois ${ }^{2}$
}

${ }^{1}$ Centre for Environment, Fisheries and Aquaculture Science (CEFAS); Lowestoft Laboratory; Pakefield Road, Lowestoft Suffolk NR33 OHT U.K.

${ }^{2}$ Institut Français de Recherche pour l'Exploitation de la Mer (IFREMER); Centre de Recherche

Halieutique UMR MARBEC (MARine Biodiversity Exploitation and Conservation); Avenue Jean Monnet, CS 3017134203 Sète France

*Corresponding author : J. R. Ellis, email address : ïm.ellis@cefas.co.uk

\begin{abstract}
:
There is a need to better understand the survivorship of discarded fishes, both for commercial stocks and species of conservation concern. Within European waters, the landing obligations that are currently being phased in as part of the European Union's reformed common fisheries policy means that an increasing number of fish stocks, with certain exceptions, should not be discarded unless it can be demonstrated that there is a high probability of survival. This study reviews the various approaches that have been used to examine the discard survival of elasmobranchs, both in terms of at-vessel mortality (AVM) and post-release mortality (PRM), with relevant findings summarized for both the main types of fishing gear used and by taxonomic group. Discard survival varies with a range of biological attributes (species, size, sex and mode of gill ventilation) as well as the range of factors associated with capture (e.g. gear type, soak time, catch mass and composition, handling practices and the degree of exposure to air and any associated change in ambient temperature). In general, demersal species with buccalpump ventilation have a higher survival than obligate ram ventilators. Several studies have indicated that females may have a higher survival than males. Certain taxa (including hammerhead sharks Sphyrna spp. and thresher sharks Alopias spp.) may be particularly prone to higher rates of mortality when caught.
\end{abstract}

Keywords : batoids, by-catch, discards, dogfish, sharks, survival. 


\section{INTRODUCTION}

Many fisheries management bodies are currently trying to reduce discards in fisheries, whether this be to reduce regulatory discards (and so minimising waste) or to minimise bycatch of vulnerable marine species. Reducing discards is a central tenet of the European Unions's (EU) reformed Common Fisheries Policy (CFP) and an obligation to land all catches of species subject to catch limits (the so-called 'discard ban') is to be phased in for various fisheries over the period 2015-2019 (EU, 2013). CFP reform, however, also notes that "The landing obligation should be introduced on a fishery-by-fishery basis. Fishermen should be allowed to continue discarding species which, according to the best available scientific advice, have a high survival rate when released into the sea". The interpretation of what constitutes 'high' survival, however, may vary between fisheries and taxa, and has not been quantified by the EU.

Elasmobranch fish are widely recognised as susceptible to overexploitation (Ellis et al., 2008a). Within European waters, several stocks are considered depleted and, in the most extreme cases, species such as angel shark Squatina squatina (Linnaeus 1758) and white skate Rostroraja alba (Lacepède 1803) have been extirpated from areas of former habitat (ICES, 2015). Given the high conservation interest in elasmobranch stocks, a variety of national and international management measures have been introduced to protect the more vulnerable species and to ensure the sustainable exploitation of commercially-exploited species. The efficacy of management actions, however, can be dependent on the degree of discard survival.

Within the ICES area, several elasmobranchs have been managed under the traditional EU system of Total Allowable Catches (TACs), including skates (Rajiformes), spurdog Squalus 
acanthias Linnaeus 1758 and some deep-water sharks. There have also been calls to introduce 'catch limits' for other elasmobranch species that are not currently subject to management (e.g. smooth-hounds Mustelus spp.). Hence, a variety of elasmobranchs may need to be considered in relation to possible future landing obligations in European waters. The CFP states that the landings obligation shall not apply to "species for which scientific evidence demonstrates high survival rates, taking into account the characteristics of the gear, of the fishing practices and of the ecosystem" (EU, 2013).

Consequently, there is a need to understand the fate (discard-retention pattern) and discard survival of such species. Furthermore, justifying the potential benefits of 'non-retention' management measures, as has been applied to certain skate stocks (EU, 2016), also requires an appropriate level of knowledge regarding the likely mortality of fish discarded.

Under the CFP, the landing obligation does not apply to those species for which "fishing is prohibited and which are identified as such in a Union legal act" (EU, 2013). Species that are currently subject to prohibitions include sawfish (Pristidae), manta and mobulid rays (Mobulidae), basking shark Cetorhinus maximus (Gunnerus 1765), white shark Carcharodon carcharias (Linnaeus 1758) and porbeagle shark Lamna nasus (Bonnaterre 1788) (all waters), S. squatina (Union waters), guitarfish (Rhinobatidae) in Union waters of ICES subareas I-XII, as well as various skates (Rajidae) and deep-water sharks in certain areas (EU, 2016). Whilst such species will not be included under the landing obligation, an appropriate knowledge of both bycatch rates and discard survival are required if the efficacy of prohibited status is to be gauged.

Similarly, several other Regional Fisheries Management Organisations (RFMOs) mandate or encourage that certain elasmobranchs are released when caught. For example, ICCAT 
recommend that Contracting Parties "prohibit, retaining onboard, transshipping, landing, storing, selling, or offering for sale any part or whole carcass" of bigeye thresher shark Alopias superciliosus Lowe 1841 (Recommendation 2009-07), silky shark Carcharhinus falciformis (Müller \& Henle 1839) (Recommendation 2011-08), oceanic whitetip shark Carcharhinus longimanus (Poey 1861) (Recommendation 2010-07) and all hammerhead sharks (Family Sphyrnidae, except bonnethead shark Sphyrna tiburo (Linnaeus 1758)) (Recommendation 2010-08). Similarly, Contracting parties to the GFCM should ensure that tope Galeorhinus galeus (Linnaeus 1758), if caught by bottom-set nets, longlines or tuna traps "shall be promptly released unharmed and alive to the extent possible".

Given the increasing conservation and management interest in elasmobranch fish, both in European seas (including in relation to the landing obligation) and internationally, and that the effectiveness of potential management measures will be highly dependent on the degree to which fishing mortality would be reduced, a review of studies examining discard mortality of elasmobranchs is provided below. This includes a review of the various approaches that have been developed, an overview of studies by broad category of gear, and a synopsis of available data by taxonomic group.

\section{APPROACHES TO EVALUATING DISCARD MORTALITY}

In general terms, the mortality is here considered to be primarily a function of at-vessel mortality (AVM), which is the proportion of fish that are dead when the fish are brought on board (or alongside) a fishing vessel, and post-release mortality (PRM), which is the proportion of fish that are released from the vessel or gear alive but do not survive in the short term due to succumbing to injuries sustained or through predation by opportunistic 
predators and scavengers. Whilst capture in commercial gears can cause physical damage, it has been suggested that elasmobranchs can have a high capacity for physical injuries to be healed (Chin et al., 2015), although empirical data for fishing-related injuries are lacking and this perception is based mostly on anecdotal observations.

The capture of fish can result in both physical damage (e.g. following interactions with the fishing gear, abrasion with other contents of a trawl net, impact of scavengers on fish caught in set nets and on lines) as well as physiological stress (e.g. through increased anaerobic muscular activity, barotrauma if raised from depth, impaired respiration and air exposure, which can also include exposure to different ambient temperatures), and the handling of captured fish as they are discarded can cause further physical and physiological trauma (Chopin \& Arimoto, 1995; Davis, 2002; Poisson et al., 2014b). The impact of these different factors can vary not only between species, but also between sex and size, season (as a function of differences in air and water temperatures) and some may be exacerbated by poor sea states (Davis, 2002; Moyes et al., 2006; Hoffmayer et al., 2012; Benoît et al., 2013; Coelho et al., 2013).

In addition to being brought on board fishing vessels, there is also the potential for fish to become entangled in fishing gear, whether during escape or from encountering previously lost gear, which can also lead to mortality or impact on health state. Injuries following capture have been documented for various elasmobranchs (Schwartz, 1984; Seitz \& Poulakis, 2006; Kabasakal, 2010; Wegner \& Cartamil, 2012).

It is important to recognise that discard mortality encompasses both AVM and PRM, where a proportion of those fish discarded 'alive' may die in the short-term as a consequence of any physical injury, trauma and physiological stress sustained during capture and handling 
(Pollock \& Pine, 2007; Poisson et al., 2014a). Injured fish may be also prone to infection (Borucinska et al., 2002; Adams et al., 2014), more susceptible to attack by predators and scavengers (Davis, 2002) or have sustained physiological damage that may affect the feeding and swimming behaviour, growth, the immune system or reproductive biology (Skomal, 2007), even over the longer term.

An increasing number of studies have used a combination of approaches so that AVM and PRM can be assessed, but it should also be remembered that some of these methods (e.g. maintenance in tanks, blood sampling or tagging) can also confer some degree of handlingor captive stress that may confound estimates of PRM (Pollock \& Pine, 2007). In order to better differentiate the components of PRM that may relate to the capture event, as opposed to any handling associated with the scientific method employed, discard survival studies should aim to employ a more benign capture technique as a 'control' (Beardsall et al., 2013).

\section{QUALITATIVE HEALTH SCORES}

Many studies have assigned the health, condition or vitality of the fish assessed, typically using a subjective evaluation by the field investigator(s) and not always with pre-defined descriptions. Such evaluations can range from more simple 'alive' or 'dead' scores (Stobutzki et al., 2002) to categories of three (lively, sluggish, dead) or five (excellent condition, good, moderate, poor, dead) health states. The assignment of fish within categories is to a certain degree arbitrary, and whilst using a larger number of categories has some benefits, these may be better in studies with a restricted number of assessors. More extensive field programmes involving multiple field workers may benefit from a more restricted number of categories. 
Some studies (e.g. Benoît et al., 2010b) have used pre-defined criteria to assess more objectively the degree of external damage and/or vitality (Table I).

Such studies allow large numbers of fish to be assessed in the field very rapidly and cheaply, including during on-going observer programmes that collect data during normal fishing operations. Whilst providing useful information on AVM, often with larger sample sizes that can be attained in dedicated research projects, it does not necessarily provide appropriate information on PRM in the short and longer-term, which a range of other methods can help address (Skomal, 2007).

Some scientific studies have scored fish in relation to a 'Behavioural Release Condition Score' (BRCS), whereby the vigour and vitality of fish is scored on a qualitative scale when released, ranging from when fish actively swim away, to more moribund fish that sink and show minimal movements (e.g. Hyatt et al., 2016). Studies have found good correlations between BRCS and blood chemistry, and so this may be serve as a better indicator than vitality at capture. Such approaches, however, have not been used widely in fishery-dependent studies, possibly because there is a greater variation in sea state, light levels, vessel speed and water clarity which would impact on the ability for such data to be collected effectively.

Elasmobranch fish are able to evert part of their spiral intestine (through the cloaca) or stomach (through the mouth), which may aid in the expulsion of indigestible food remains (Crow et al., 1990; Sims et al., 2000; Brunnschweiler et al., 2011). Whilst elasmobranchs captured in commercial fisheries can be found with parts of the alimentary tract everted, the extent to which such organs may be damaged, and influence the probability of survival following release, is unclear. 


\section{SURVIVAL TANKS}

Several studies have monitored the survival of smaller demersal sharks and skates for the days following capture using on-board survival tanks (Revill et al., 2005; Benoît et al., 2010a), cages or pens anchored to the sea floor (Mandelman \& Farrington, 2007b) or after transporting fish to tanks on land for subsequent study (Mandelman \& Farrington, 2007b). Such approaches provide more robust information on the survival of fish with different health states over a period of a few days. These approaches are, however, more difficult to employ for larger and faster-swimming species. Additionally, other factors such as captive stress, stocking densities and environmental conditions may also contribute as artefacts to estimates of PRM. It has also been suggested that the use of single flow-through systems and stacked individual tanks may confound effects (e.g. though the transferral of some waste products and cross-infection) and may be better considered as pseudo-replicates (Broadhurst et al., 2006).

Revill et al. (2005) used survival tanks mounted in a rack with a constant flow of fresh sea water to examine the survival of lesser-spotted dogfish Scyliorhinus canicula (Linnaeus 1758) for periods of $36-60 \mathrm{~h}$ following capture in commercial $8 \mathrm{~m}$ beam trawl with chain mat. This is a relatively small demersal species (specimens in this study were $40-70 \mathrm{~cm}$ total length, $L_{T}$ ), and so it is amenable to such studies. Short-term survival was demonstrated to be very high $(98 \%)$ in this study.

Rulifson (2007) caught S. acanthias by commercial otter trawl and gillnet, with sampled fish left on deck for $0.17-0.25 \mathrm{~h}$ (to simulate the processes that may be expected during commercial operations) before being categorised as live or dead (with injuries also noted). Sub-samples ( $n=480$ for each gear type) were then placed in sea pens that were anchored 
for $48 \mathrm{~h}$. The direct capture mortality was $0 \%$ for trawl $(0.5-1.5 \mathrm{~h}$ tow duration) and $17.5 \%$ for gillnet (19.5-23.5 h soak time). Following $48 \mathrm{~h}$ in sea pens, there was no further mortality of trawl-caught S. acanthias, whereas there was a further $33 \%$ mortality for those caught by gillnet. Mandelman \& Farrington (2007b) also used sea pens to estimate survival of $S$. acanthias and found $29 \%$ mortality (after $72 \mathrm{~h}$ ) of caged fish caught by trawl and $24 \%$ mortality for fish caught on short long-lines. The latter was considered a more benign capture technique, and so the mortality in captivity may have been influenced by other factors such as captive stress, physical contact with the sea pen or the presence of scavenging isopods (Mandelman \& Farrington, 2007b).

\section{CONVENTIONAL TAGGING}

Mark-recapture programmes have been used in numerous discard survival studies, primarily as a way of validating that fish assessed as healthy had indeed survived. Many other factors also influence recapture and tag return rates, including tag shedding, emigration, publicity of tagging scheme, degree of active participation by fishers and degree of geographical overlap between fishing activity and the stock of fish tagged (Kohler \& Turner, 2001).

Ellis et al. (2008b) tagged and released thornback ray Raja clavata Linnaeus 1758 caught in various trawls as well as on longlines and by gillnet. Preliminary analyses of these data indicated that the tag return rates were highest for fish caught by longline (22.2-23.6\%) and drift trammel net (24.8\%), slightly lower for trawl (15.7\% for all data combined, but ranging from $12.7-24 \%$ for individual vessels) and were lowest in gillnet fisheries (9.5\%). It was unclear as to whether the reduced recapture rate in the latter gear was due to higher PRM or, as the latter vessel had operated at the southern-most part of the survey area, whether 
there had been spatial differences between fishing ports in terms of the likelihood of tags being returned.

Whereas the results of mark-recapture programmes can confirm that there is some longerterm survival, the exact degree of discard survival may not be quantifiable, although there are potential approaches to infer the relative survival, for example when examining the impacts of different gears. For example, Hueter et al. (2006) compared the relative survival of sharks captured by gillnet and then tagged and released. All sharks were assigned a condition (on a score of 1-5), and differences in the return rates between these samples were modelled to inform on the mortality, assuming that there was no delayed post-capture mortality for fish in the best condition. For example, the recapture rates of blacktip shark Carcharhinus limbatus (Müller \& Henle 1839) that had been released in 'good', 'fair', 'poor' and 'very poor' conditions were $6.3 \%, 4.2 \%, 3.6 \%$ and $1.1 \%$, respectively. Similarly, the recapture rates of $S$. tiburo were $6.0 \%, 4.8 \%, 2.6 \%$ and $1.2 \%$, respectively. The results from this study suggested that $31 \%$ and $40 \%$ of tagged and released C. limbatus and S. tiburo died as a result of capture. Given an observed AVM of $40 \%$ (C. limbatus) and $37 \%$ (S. tiburo), the overall capture mortalities were then estimated at $58 \%$ and $62 \%$ for these two species.

Analyses of mark-recapture data for a broader range of species in any given geographic region to try and determine whether tag return rates can be correlated with varying categories of survivorship (e.g. low, medium, high) could usefully be undertaken. If return rates from markrecapture studies can be used to provide surrogates of survival, this could allow markrecapture data to be used a cost-effective option for identifying which species could be excluded from landings obligations. 


\section{ELECTRONIC TAGGING}

Electronic tags have been used extensively to better understand the movements and behaviour of elasmobranchs (Hammerschlag et al., 2011), but few of these studies have been undertaken to understand the post-release behaviour and fate of elasmobranchs caught under commercial fishing conditions (Hoolihan et al., 2011). These studies have generally used either acoustic or archival tags. Whilst providing much more robust longer-term data for individual fish, studies using archival tags are usually limited in terms of sample size, due to the higher costs of such tags. Furthermore, in some studies using electronic tags, it is possible that specimens in better condition may be selected preferentially for tagging, and that tagged fish may be subject to more careful handling practices, whereas normal commercial fishing and handling practices may not be so benign.

\section{ACOUSTIC TAGS}

Short-term monitoring of fish behaviour using acoustic tags and either 'listening stations' and/or the active tracking of tagged fish with hydrophones has been used most successfully with coastal elasmobranchs. Early studies with this technology were conducted primarily to understand the fish behaviour, and so data are unlikely to be representative when considering mortality. Some recent studies have captured elasmobranchs and subsequently tracked individual fish tagged with self-releasing ultrasonic transmitters to understand mortality (Gurshin \& Szedlmayer, 2004), but such studies are generally only conducted for short periods of time (typically periods of several hours).

ARCHIVAL TAGS 
Electronic tags, including pop-up satellite archival tags (PSATs) and pop-off data storage tags (DSTs), have also been used to quantify longer-term survival of various elasmobranchs (Campana et al., 2009a; Poisson et al., 2014a; Francis \& Jones, 2016).

Whilst several published studies have deployed PSATs and other types of electronic tags on a variety of elasmobranchs caught by commercial gears, many of these studies have aimed to better understand the behaviour and ecology of the species in question and have so tended to release individuals deemed likely to survive. Campana et al. (2009a) tagged a random sample of blue shark Prionace glauca (Linnaeus 1758$)\left(n=40 ; 124-251 \mathrm{~cm}\right.$ fork length, $\mathrm{L}_{\mathrm{F}}$ ) with PSATs, including healthy and injured animals. Based on the time-depth-temperature information from PSAT tags, healthy $P$. glauca that were hooked in the mouth all survived (n $=10)$, whilst injured sharks that were hooked in the mouth $(n=19)$ or had swallowed the hook $(n=8)$ showed $32 \%$ and $38 \%$ mortality, respectively. Specimens categorised as 'injured' showed 33\% mortality, with overall mortality estimated at 35\% (Campana et al., 2009a).

Lower rates of mortality were estimated for P. glauca caught in a Pacific fishery for swordfish Xiphias gladius Linnaeus 1758 (Musyl et al., 2009), which could be related to handling practices and gear configuration, especially hook type (Campana, 2009b). A subsequent metaanalysis of available data for post-release survival for this species indicated PRM of about $15 \%$ (Musyl et al., 2011).

There are, however, some issues that also need to be considered with electronic tags. Firstly, as they are generally larger than conventional, non-electronic tags, they cannot always be deployed on the juveniles of some species. Secondly, although the returned data can be used to infer 'normal' behaviour from 'recovery behaviour', this can sometimes be difficult to quantify and, depending on the nature of tag attachment, post-release mortality or evidence 
of stress, may encompass elements from both the capture and tagging procedures. Finally, over what period should any observed mortality be attributed to the original capture process? Poisson et al. (2014a) adopted a conservative approach and considered that all observed deaths were due to the capture event, whilst Hutchinson et al. (2013) considered mortalities that occurred within 10 days of release to be a result of the fishing event.

\section{BLOOD CHEMISTRY}

Fish undertaking severe physical activity during the capture process can subsequently die, as anaerobic exercise leads to an accumulation of lactate and reduced $\mathrm{pH}$ in the blood. The buildup of lactate and/or intracellular acidosis have been hypothesised to contribute to mortality (Wood et al., 1983). Blood chemistry has been increasingly used in studies on captured elasmobranchs in order to evaluate the levels at which various blood parameters (e.g. concentrations of lactate and potassium) may be correlated with physiological stress and trauma and likelihood of survival (Wells \& Davie, 1985; Hoffmayer \& Parsons, 2001; Mandelman \& Farrington, 2007a; Brill et al., 2008; Mandelman \& Skomal, 2009; Brooks et al., 2012; Hyatt et al., 2012; Marshall et al., 2012; Skomal \& Mandelman, 2012; Dapp et al., 2016). Most studies have examined various blood parameters in relation to quantified stress-causing events (e.g. capture time). Skomal \& Chase (2002) examined the blood chemistry of $P$. glauca (and tuna and billfish) after capture by rod and line, with blood $\mathrm{pH}$ decreasing and blood lactate increasing as fight time increased. More recently, increasing numbers of studies have applied such methods to commercially caught fish. Brooks et al. (2012) examined the blood chemistry of Caribbean reef shark Carcharhinus perezi (Poey 1876) caught in research longlines with hook-timers, although only specimens hooked in the jaws were included. 
Concentrations of lactate, carbon dioxide and glucose all increased with hooking duration for periods of up to $3 \mathrm{~h}$, before declining or stabilising.

Some studies have combined multiple approaches, with Moyes et al. (2006) using PSAT tags and blood chemistry to try and predict post-release survival of longline caught $P$. glauca. Here, concentrations of certain plasma metabolites (lactate, $\mathrm{Mg}^{2+}, \mathrm{K}^{+}$and $\mathrm{Ca}^{+}$) were seemingly elevated in more moribund sharks. In a study of the longline catch in the eastern Pacific, Hight et al. (2007) examined the plasma concentrations of adrenaline, noradrenaline and lactate in pelagic sharks ( $P$. glauca, shortfin mako Isurus oxyrinchus Rafinesque 1810 and common thresher Alopias vulpinus (Bonnaterre 1788)) that were then tagged and released. Based on the observed blood chemistry of those individuals that were subsequently recaptured (over periods of 34-1594 days), it was suggested that ca. $80 \%$ of released sharks would also have been expected to survive.

The adenylate energy charge (AEC), which is based on the relative proportions of adenosine monophosphate (AMP), adenosine diphosphate (ADP) and adenosine triphosphate (ATP), has also been proposed as a tool with which to examine metabolic stress (Guida et al., 2016a). This study indicated that liver and white muscle were both sensitive to metabolic stress, with the latter potentially sampled non-lethally through biopsies.

Whilst such studies provide valuable biological information on understanding stress-related issues and how they may correlate with survival, such approaches might not always be the most practical approach to providing quantitative estimates of AVM and PRM under commercial fishing operations, which are the key questions for fisheries management.

\section{LABORATORY STUDIES}


Laboratory investigations have been undertaken to mimic the capture stress associated with gillnet and longline capture (Frick et al., 2009, 2010a, 2012) and trawl capture, including tow duration, crowding and exposure to air (Frick et al., 2010b). These studies reported no mortality of the demersal Port Jackson shark Heterodontus portusjacksoni (Meyer 1793) but mortality of gummy shark Mustelus antarcticus Günther 1870 was $8 \%$ (longline experiments), up to $70 \%$ (gillnet experiments), and variable in trawl experiments (Frick et al., 2010a, b). Australian swellshark Cephaloscyllium laticeps (Duméril 1853) subjected to simulated gillnet capture also showed no mortality (Frick et al., 2009).

Heard et al. (2014) used experimental tanks and a trawl cod-end to simulate trawl capture in order to evaluate the effect of blood sampling only (control, $n=8$ ), trawl time ( $1 \mathrm{~h}$ and $3 \mathrm{~h}, \mathrm{n}$ $=8$ each), air exposure ( $0.17 \mathrm{~h}$ air exposure following $1 \mathrm{~h}$ trawl simulation, $\mathrm{n}=8)$ and crowding (five fish per cod-end, $\mathrm{n}=10$ ) on the physiology of sparsely-spotted stingaree Urolophus paucimaculatus Dixon 1969. No immediate mortality was noted, although some postexperimental mortality occurred over the following 48-96 h. No mortality was observed for either the control group or fish subject to $1 \mathrm{~h}$ trawl duration, but there was $37.5 \%$ mortality following $3 \mathrm{~h}$ trawl duration, $12.5 \%$ following $1 \mathrm{~h}$ trawl and $0.17 \mathrm{~h}$ air exposure, and 20\% mortality for the crowding experiment.

To examine the impacts of aerial exposure at different temperature regimes (simulating what would occur to captured fish prior to discarding), Cicia et al. (2012) collected samples of little skate Leucoraja erinacea (Mitchill 1825) caught by otter trawl ( $<0.33 \mathrm{~h}$ tow duration) and transported them to on-shore tanks. After a 10-day period of acclimatization, fish were withdrawn from tanks and exposed to the air for $<1$ minute (control), $0.25 \mathrm{~h}$ or $0.83 \mathrm{~h}$. This method was applied in both winter (air and water temperature $=1^{\circ} \mathrm{C}$ and $4^{\circ} \mathrm{C}$, respectively) 
and summer (air and water temperature $=27^{\circ} \mathrm{C}$ and $18^{\circ} \mathrm{C}$, respectively). Fish were then examined for mortality and blood sampling taken. Mortality over the following 5 days was $0 \%, 18 \%$ and $27 \%$ (control, $0.25 \mathrm{~h}$ or $0.83 \mathrm{~h}$ aerial exposure, respectively for winter) and $37 \%$, $86 \%$ and $100 \%$ (control, $0.25 \mathrm{~h}$ or $0.83 \mathrm{~h}$ aerial exposure, respectively for summer). Whilst based on laboratory studies, it emphasises how fish subject to prolonged periods of time on deck prior to discarding can experience higher mortality, with this more pronounced in the summer, when the larger temperature differential and increased desiccation can exacerbate physiological stressors.

\section{OTHER METHODS}

Braccini et al. (2012) developed modelling approaches for which 'immediate post-capture survival' (using observer data for the numbers alive and dead) were combined with an estimate of 'delayed post-capture survival'. The latter was derived from four categorical indices (activity and response to stimuli; degree of any wounding and bleeding; damage due to sea lice; damage due to physical trauma).

A few alternative approaches to better understanding the behaviour of sharks after release have also been undertaken. For example, Skomal et al. (2007) attached a video camera over the first dorsal fin of grey reef shark Carcharhinus amblyrhynchos (Bleeker 1856) $(n=6)$ that were caught by hand-line on a Pacific atoll, with the system programmed to detach after $2 \mathrm{~h}$. Whilst such approaches allow for the short-term behaviour of individual fish to be studied and evaluated, sample sizes are often limited. Consequently, it may not allow for accurate estimates of longer-term post-release mortality and results may not be representative. 
Diver surveys and photo-identification have highlighted the potential impact of line fisheries (including recreational rod and line fisheries) on sandtiger shark Carcharias taurus Rafinesque 1810 along the east coast of Australia (Bansemer \& Bennett, 2010). This study reported that of $13-20 \%$ of identified sharks (based on sex and flank photographs) had evidence of retained gear or jaw injuries. Whilst not informing on discard mortality per se, such studies indicate that discarded sharks with jaw damage can survive release.

\section{DISCARD MORTALITY OF ELASMOBRANCHS BY GEAR}

Numerous studies have documented the elasmobranch bycatch in European fisheries in recent years (Berrow, 1994; Borges et al., 2001; Baeta et al., 2010; Storai et al., 2011; Silva et al., 2012). Despite the increased number of studies examining the issue of elasmobranch bycatch and discarding, both in European seas and worldwide, reviewed recently by Molina \& Cooke (2012), there have been comparatively few studies examining the fate of discards, especially in European fisheries. An earlier review of incidental mortality of fish in towed gears by Broadhurst et al. (2006) included only three studies that specifically addressed elasmobranchs, but there have been several studies since this time (Table II). Similarly, only limited information on elasmobranch mortality in gillnets was included in the recent review by Uhlmann \& Broadhurst (2015).

Discard mortality of elasmobranchs caught in fishing gears varies with a range of factors (Stobutzki et al., 2002; Broadhurst et al., 2006; Morgan \& Carlson, 2010; Dapp et al., 2015; Guida et al., 2016b), and these include gear type (i.e. the gear and its configuration), fishing practices (e.g. soak time, location and depth of fishing ground), species (e.g. mode of gill ventilation, thickness of skin, size and behavioural reaction to the gear) and on-board 
conditions (e.g. air temperature, time on deck, handling practices of the crew). For example, demersal elasmobranchs with thick skins and buccal pump ventilation may survive capture and handling on deck better than faster swimming taxa that are obligate ram ventilators (Revill et al., 2005; Rodriguez-Cabello et al., 2005).

The following section summarises the findings from previously published studies on discard survival, but it should be recognised that comparisons between disparate studies can be problematic, due to differing methods of catching and handling fish (Musyl et al., 2009), and also as not all studies provide full descriptions of the gears, fishing operations and handling, and environmental conditions.

If discard mortality is high in particular fisheries, and this is considered to have a detrimental effect on any given stock, then there needs to be due consideration of mitigation measures that either reduce the likelihood of capture and/or increase the chances of live discarding (Poisson et al., 2014b). In terms of reducing elasmobranch bycatch, whilst there have been numerous studies in relation to pelagic longline fisheries, options for minimising the bycatch of elasmobranchs in other fisheries are less well known (Jordan et al., 2013). Studies highlighting potential mitigation measures are addressed briefly for the broad gear types.

DEMERSAL OTTER TRAWL FISHERIES (INCLUDING PRAWN TRAWLS)

Many demersal otter trawl fisheries have a bycatch of demersal batoids and smaller sharks and, depending on the height of the net, there can also be incidental catch of larger sharks. The catchability of skates may also be influenced by the type of ground gear used on the net, as escapement can increase as the height of the fishing line above the sea floor increases (Walsh, 1992). The use of a tickler chain can also increase the catch of skates and other 
demersal elasmobranchs (Kynoch et al., 2015), as this will disturb them from the sediment. Otter trawls are generally proportionally more effective for some of the larger skates, with a greater proportion of smaller skates escaping capture, presumably passing under the fishing line or ground gear (Kotwicki \& Weinberg, 2005). The AVM of elasmobranchs caught in trawl gears may be influenced by tow duration and catch composition and weight, and PRM also affected by time on deck prior to discarding.

Rulifson (2007) reported zero mortality of trawl-caught S. acanthias (0.5-1.5 h tow duration), even after a further $48 \mathrm{~h}$ of retention in sea cages but other studies on this species have indicated a higher mortality (up to $29 \%$ over 72 h; Mandelman \& Farrington, 2007a, b). Rodríguez-Cabello et al. (2005) examined the survival of S. canicula caught in an otter trawl (Spanish 'baca' type trawl) by both research vessel ( $0.5 \mathrm{~h}$ tow duration) and commercial vessels (3-6 $\mathrm{h}$ tow duration). Fish were then placed in tanks after being on deck for $0.33-1.0$ $\mathrm{h}$ (research vessel) and 0.3-1.4 $\mathrm{h}$ (commercial vessel). The mean survival rates from research surveys and commercial trawlers were $90 \%$ and $78 \%$ respectively.

Skates (Arhynchobatidae) are a bycatch in the Falkland Island trawl fishery targeting squid, and Laptikhovsky (1994) reported that the overall survival was $59.1 \%$, with a greater proportion of females surviving $(66.7 \%)$ than males (56.4\%). Other skates (Rajidae) caught in a Canadian trawl and seine fisheries were generally in good condition, with $>80 \%$ in excellent or good condition after capture (Benoît et al., 2010a).

Prawn trawlers operate in many areas, typically fishing for penaeids. As such there is usually a high degree of ground contact, and a variety of bycatch species can be taken. Stobutzki et al. (2002) examined the immediate capture mortality of elasmobranchs once the catch was on board, but no information on longer-term survival was available. Of the sharks $(n=639$, 
species combined, but see Table II), $66 \%$ of males were dead, but only $23 \%$ of females were dead. Similarly, of the 208 batoids caught, a greater proportion of males were dead (67\%) than observed for females (56\%). Fennessy (1994) examined the AVM of a range of elasmobranchs taken in the shallow (20-45 m) prawn grounds off South Africa, and whilst $<50 \%$ for most of the demersal elasmobranchs studied, it was higher (97.6\%) for scalloped hammerhead Sphyrna lewini (Griffith \& Smith 1834).

Although there has been extensive work on bycatch mitigation for some species taken incidentally in trawls (e.g. sea turtles), there has been less work undertaken on reducing bycatch and/or improving survivorship of elasmobranchs (Griffiths et al., 2006). Indeed, many studies on the impacts of grids and other bycatch reduction devices on the selection of marketable species have focused on teleosts and commercial shellfish and have not always provided information on elasmobranchs, possibly due to small sample sizes. Nevertheless, grids have been demonstrated to reduce the catch of skates and rays in some bottom trawl fisheries (Lomeli \& Wakefield, 2013; Willems et al., 2016) and bycatch reduction devices have also been shown to reduce the catches of the shovelnose guitarfish Rhinobatos productus Ayres 1854 in Mexican shrimp trawls (García-Caudillo et al., 2000).

Brewer et al. (2006) examined the catches of prawn trawls with turtle excluding devices (TEDs) and bycatch reduction devices (BRDs). This study reported that nets with TEDs or combined TED/BRDs successfully reduced shark and ray bycatch, with upward-excluding TEDs more effective for reducing shark catches. The use of trawls with only BRDs was less successful. Belcher \& Jennings (2011) also examined the shark bycatch in a penaeid shrimp trawl fishery, with catch rates of sharks differing between net design and type of TED/BRD used. Similarly, Raborn et al. (2012) estimated that catches of blacknose shark Carcharhinus 
acronotus (Poey 1860) and S. tiburo would have been reduced by the uptake of TEDs in a penaeid shrimp fishery. The size, morphology and behaviour of elasmobranchs are key factors in understanding the potential benefits of the various excluder devices, and whilst grids can facilitate the escape of larger species, juveniles and smaller-bodied species may not benefit (Willems et al., 2016).

Trials to reduce bycatch of $S$. acanthias by incorporating an excluder grid on the trawls used in a fishery for silver hake Merluccius bilinearis (Mitchill, 1814) successfully reduced catches of S. acanthias, and improved the quality of the catch in the cod-end (Chosid et al., 2012). The $50 \mathrm{~mm}$ bar spacing used in this study allowed commercial quantities of the target species still to be caught, however this bar spacing may not be suitable for other fisheries targeting other species. Furthermore, Chosid et al. (2012) noted that S. acanthias would often become wedged in grids with wider $(64 \mathrm{~mm})$ spacings.

Some of the studies examining the use of separator grids and TEDs have found that elasmobranchs, especially batoids, can clog grids (Isaksen et al., 1992; Lawson et al., 2007; Lomeli \& Wakefield, 2013), which can then compromise the retention of target species (and so deter fishers from using such systems voluntarily). Separator grids may also be useful in preventing the capture of large sharks, for example Isaksen et al. (1992) noted that Greenland shark Somniosus microcephalus (Bloch \& Schneider 1801) would generally pass through the separating system in a shrimp trawl, although sometimes damaging this part of the trawl.

Given that skate and ray mortality can be influenced by the weight of the catch (Fennessy, 1994; Enever et al., 2009) and presumably the abrasive nature of some catch components, measures to reduce the retention of, for example, benthic invertebrates (many of which can be abrasive) should decrease AVM. Such approaches can also reduce the time taken for 
fishers to process catches and improve the quality of marketable fish. The effects of different configurations of cod-end mesh on the survival of skates were explored by Enever et al. (2010). The size, morphology and demersal nature of batoids means that they will often be caught in mixed demersal trawl fisheries, however Enever et al. (2010) indicated that changing from $80 \mathrm{~mm}$ diamond to $100 \mathrm{~mm}$ square mesh in the cod-end would improve the condition of skates, so increasing the potential survival of discarded individuals.

Kynoch et al. (2015) showed that not using a tickler chain can reduce the catch of demersal elasmobranchs in demersal trawl fisheries, the absence of this chain can also reduce the catch of some commercially valuable fish, in this instance anglerfish Lophius spp., and so such measures not always be popular with the fishing industry.

Whilst several studies have examined the AVM and/or short-terms survival of trawl-caught elasmobranchs, most studies have presumably focused on those specimens that have been retained in the cod-end of the trawl. Depending on the mesh sizes of the trawl net, however, elasmobranchs (particularly smaller dogfish) may be entrapped in the meshes and exposed to more physical trauma. The vitalities of enmeshed elasmobranchs in comparison to those that have passed to the cod-end have, however, not been quantified.

\section{BEAM TRAWL FISHERIES AND DREDGES}

Beam trawl catches can be subject to physical damage, both from the gear, including the chain mat or tickler chains, as well as from any benthic invertebrates (including abrasive taxa such as echinoderms) and rocks that may be caught in the net. One of the earliest studies of discard survival in this gear was that of Kaiser \& Spencer (1995), who maintained trawl-caught organisms (including cuckoo ray Leucoraja naevus (Müller \& Henle 1841) and S. canicula) in 
on-board survival tanks. The gear ( $4 \mathrm{~m}$ beam trawl) and fishing protocol (tow duration $=0.5$ h) were generally more consistent with research fishing and so less representative of commercial fishing. This study indicated that $59 \%$ of $L$. naevus and $90-94 \%$ of S. canicula were alive five days after capture.

Revill et al. (2005), using survival tanks, found that the survival of $S$. canicula $(n=120)$ was very high in the short-term ( $98 \%$ over periods of $36-60 \mathrm{~h}$ ), with these samples caught under commercial conditions ( $2 \mathrm{~h}$ tow duration; $4-5$ knot trawl speed; waters of $60-80 \mathrm{~m}$ depth).

Skates may also be an occasional bycatch in dredge fisheries for scallops. For example, $L$. naevus is a frequent bycatch species in European dredge fisheries for scallop Pecten maximus and queen scallop Aequipecten opercularis, with a high proportion of these immature (Craven et al., 2012). Whilst discard survival information is not available for northern European dredge fisheries, there are some data from elsewhere in the world. Benoît et al. (2010b) reported that nearly $92 \%$ of winter skate Leucoraja ocellata (Mitchill 1815) caught in a commercial scallop fishery were in excellent or good health state.

\section{GILL AND TANGLE NET FISHERIES}

A range of elasmobranchs are an incidental bycatch in gillnet fisheries (Benjamins et al., 2010), and mortality in these gears can be relatively high (Berrow, 1994). Furthermore, some elasmobranchs may be caught in lost gillnets that continue to fish (Kaiser et al., 1996). In general, at-vessel mortality in such gears is described in relation to the soak time of the net, whereas in reality mortality will be influenced by the time the fish has spent entangled in relation to the respiratory mode of the species (i.e. elasmobranchs with buccal-pump ventilation of the gills will survive longer in a net than those species that are obligate ram 
ventilators). In some areas there are abundant scavengers, such as some isopods (Fig. 1), and these may increase the mortality of fish trapped in set gears (Bendall et al., 2012).

Hyatt et al. (2012) looked at the blood chemistry of carcharhiniform sharks caught in experimental gillnets and longlines, with higher lactate concentrations and a greater $\mathrm{pH}$ in gillnet-caught fish, emphasising the greater physiological impact of capture by gillnet. Rulifson (2007) reported that the initial mortality of gillnet-caught S. acanthias was $17.5 \%$ (19-24 $\mathrm{h}$ soak time), but that there was further mortality for at least the next $48 \mathrm{~h}$, resulting in an overall mortality estimate of 55\%. Thorpe and Frierson (2009) examined the survivorship of four shark species (Atlantic sharpnose shark Rhizoprionodon terraenovae (Richardson 1836), C. acronotus, C. limbatus and S. tiburo) taken in gillnets, with an overall mortality of $78.6 \%$. Similarly, high mortality rates have also been observed for C. limbatus (58\%) and S. tiburo (62\%) caught by gillnet in scientific surveys, even with short $(1 \mathrm{~h})$ soak times (Hueter et al., 2006).

Bottom-set fixed nets can also have a bycatch of larger sharks. Valeiras et al. (2001) reported on 12 instances of C. maximus being taken in such gears (termed 'trasmallo') from northwestern Spain, of which three were landed and sold, two released alive, three discarded dead and four of unknown fate.

Whilst not a traditional 'fishery', the protective shark nets deployed off tourist beaches in the southern hemisphere capture a variety of elasmobranchs. Reid \& Krogh (1992) reported on the proportion of fish that were alive when the shark nets off New South Wales (Australia) were checked (usually at periods of 12-48 h). As expected, demersal species had the lowest mortality (3.3\% for horn sharks Heterodontus spp. and $15.4 \%$ for wobbegong Orectolobus 
spp.), with a much higher mortality for ram ventilators ( $91 \%$ in mako sharks Isurus spp. and $98 \%$ in hammerheads).

Potential bycatch mitigation measures in gillnet fisheries could include spatial and/or temporal restrictions, restricted lengths of net, limiting soak times, changes to mesh size, hanging ratio and height of the net, and modifying the thickness and colour of netting material (Thorpe \& Frierson, 2009; Baeta et al., 2010). However, there have been few such studies to date and appropriate field studies in conjunction with the fishing industry would be required to gauge which measures would be most effective to reduce incidental shark bycatch and/or mortality. He (2006) examined the use of a 'tie-down' gillnet in relation to a standard gillnet used in a fishery for cod Gadus morhua Linnaeus 1758. The lower height of the 'tie-down' gillnet reduced the catch of $S$. acanthias, but the catch of skates increased four-times and catches of $G$. morhua also decreased.

Whilst a proportion of fish can survive capture and release from gillnets, some individuals escaping from such gears may retain monofilament around parts of the body (Schwartz, 1984; Seitz and Poulakis, 2006; Fig. 2), but it is uncertain as to how frequent an event this is and how this subsequently affects individuals.

The presence of trapped fish in gillnets may attract opportunistic predators, and whilst there have been numerous studies aiming to reduce both depredation by, as well as entanglement of, marine mammals, the interactions of elasmobranchs with gillnet catches have received less attention. Rafferty et al. (2012) reported that S. acanthias would opportunistically depredate G. morhua, haddock Melanogrammus aeglefinus (Linnaeus 1758), Lophius spp. and skates taken in gillnets in the Georges Bank area, with S. acanthias also ranked fourth (in terms of biomass) and fifth (value of the catch) of the species caught in this study. Waples et 
al. (2013) noted that depredation on gillnet-caught Spanish mackerel Scomberomorus maculatus (Mitchill 1815) by sharks was greater than observed for bottlenose dolphin. Further studies to ascertain the extent to which elasmobranchs may be attracted to gillnet catches, and so at potential risk of entanglement, could usefully be undertaken.

\section{LONGLINE FISHERIES}

Longline gears may be deployed in demersal, pelagic and deep-water fisheries. Longline fisheries traditionally have a large shark bycatch (or they may even by the target species), and mortality can be highly variable between species (Gilman et al., 2008). The time spent hooked is an important factor to consider, especially for those fisheries with potentially long soak times. Morgan \& Carlson (2010) used hook timers on a longline, and so were able to determine how mortality of several carcharhiniform shark species increased with increasing time hooked. Whilst the use of hook timers in scientific studies has increased in recent years, studies on commercial vessels have generally examined mortality in relation to overall soak time (Boggs, 1992; Poisson et al., 2010).

In terms of pelagic longline fisheries, Megalofounou et al. (2005) reported the health state for sharks caught in swordfish and tuna fisheries in the Mediterranean. Although the overall proportions of sharks dead on capture was low (5\%), data from this study indicated that whereas $84.4 \%$ of $P$. glauca were in either good or fair condition, this proportion was lower in lamniform sharks ( $54.8 \%$ for $I$. oxyrinchus and $43.8 \%$ for $A$. vulpinus). This study also revealed subtle differences in the health state of sharks between different longline fisheries, with a greater proportion of sharks in good or fair condition in swordfish longline fisheries (82-97\%) than in longline fisheries targeting albacore Thunnus alalunga (Bonnaterre 1788) 
(69\%). Diaz \& Serafy (2005) reported that about $69 \%$ of longline-caught $P$. glauca were released alive, and that at-vessel mortality was lower for larger individuals and lower for fish caught in sets with a short soak time

High estimates of $P$. glauca survival were also observed in longline fisheries in the Pacific, with 4-5.7\% mortality reported (Walsh et al., 2009). In contrast, Campana et al. (2009a) estimated a higher overall mortality of $P$. glauca caught in the Canadian Atlantic longline fishery, with AVM observed to be $20 \%$, and live fish either injured (44\%) or healthy (36\%). Studies using PSATs (see above) enabled more robust estimations of post-release mortality, resulting in an estimated $35 \%$ overall mortality. More recent studies have provided better estimates of hooking mortality and post-release mortality for $P$. glauca, I. oxyrinchus and $L$. nasus taken in the Canadian longline fishery (Campana et al., 2016). For example, 41.6\% (and 14.6\%) of $L$. nasus were considered healthy (injured) following capture. Data from PSATs indicated that the majority (89.7\%) of healthy fish survived, but only one of the four injured fish tagged survived, resulting in an estimated $59 \%$ overall mortality (Campana et al., 2016). Comparable data for the other species indicated an overall mortality of $23.1 \%$ for $P$. glauca and $49.3 \%$ for I. oxyrinchus.

Skates caught in Canadian bottom longline fisheries were generally in good condition (Benoît et al., 2010a), with $>80 \%$ categorised as either excellent or good condition after capture. Whilst demersal skates appear to generally survive capture on longlines, Morgan \& Carlson (2010) estimated higher mortalities (15-91\%) for the different shark species taken on bottom longlines off Florida.

Some European nations had directed longline fisheries for L. nasus and S. acanthias, though these fisheries no longer operate given the zero TAC currently in place for these species. 
Currently most of the longline effort conducted by the English fleet is from smaller inshore vessels deploying demersal longlines over a short soak time, and the smaller elasmobranchs taken in these fisheries exhibit low at-vessel mortality (Ellis et al., 2008b). For example, the inshore fleet operating in the southern North Sea often set longlines where the main species caught include R. clavata, S. acanthias (seasonally) as well as larger teleosts (G. morhua and bass Dicentrarchus labrax (Linnaeus 1758)). Soak times in this fishery are normally $2-4 \mathrm{~h}$, and most fish are lively and unwanted elasmobranchs can be returned to the sea (Ellis et al., $2008 \mathrm{~b}$ ). In other areas, longlines may be set overnight ( $24 \mathrm{~h}$ soak time), and whereas the elasmobranchs caught are also generally lively, these fish may sustain a greater degree of jaw damage (Ellis et al., 2012). Some sharks, however, seem capable of surviving jaw damage and individuals showing varying degrees of recovery can be observed (Fig. 3).

There is less information for elasmobranchs caught in deep-water longline fisheries. Endicott and Agnew (2004) examined the survival of skates taken as a bycatch in the South Georgia toothfish fishery, with longlines fished at 746-1913 m. Whilst no information on AVM was presented, the results from maintaining Amblyraja spp. $(n=95)$ in tanks on deck suggested that about $34 \%$ would be expected to survive.

Bycatch mitigation measures for longline fisheries are relatively well studied, and whereas results from various trials have ostensibly provided encouraging results in terms of reducing elasmobranch bycatch, a recent meta-analysis of published studies has questioned the effectiveness of some suggested measures (Favaro \& Côté, 2015). There have been numerous publications on the potential use of magnets and electropositive metals and, as these were addressed in the recent review by Favaro \& Côté (2015), they are not appraised further here. 
Several studies have highlighted that sharks caught with circle hooks may survive better than those caught with J-hooks (Carruthers et al., 2009; Afonso et al., 2011; Fernandez-Carvalho et al., 2015), although other studies examining catch rates and mortality of sharks with different longline configurations have indicated circle hooks may not have such a great impact (Yokota et al., 2006; Afonso et al., 2012; Amorim et al. 2014). A meta-analysis of available data led Godin et al. (2012) to conclude that circle hooks did not affect catch rates of sharks, but did reduce at-vessel mortality, because these hooks are more often hooked in the mouth or jaw and are less frequently ingested (gut-hooked). Hook size can also influence catch rates, for example Piovano et al. (2010) found a significant reduction in the catch of pelagic stingray Pteroplatytrygon violacea (Bonaparte 1832) when using 16/0 circle hooks than J-hooks.

Shark catches can be reduced with nylon leaders (traces), as sharks may bite through monofilament more easily than wire (Ward et al., 2008; Afonso et al., 2012). For example, Ward et al. (2008) reported the catch rates of sharks (all species combined) on nylon and wire leaders used on pelagic longlines off north-eastern Australia were 1.17 and 2.75 sharks per 1000 hooks deployed, respectively. However, it cannot be assumed that all sharks that have bitten through nylon leaders will survive.

The use of bait (or hook) strippers on some longline vessels can increase the severity of injuries to the mouth and jaws. Whilst not quantified for elasmobranchs, Kaimmer (1994) found that Pacific halibut Hippoglossus stenolepis Schmidt 1904 that were de-hooked by a bait-stripper not only had a much higher mortality than when fish had the hook removed manually, but also those with sub-lethal injuries then exhibited impaired growth.

Other potential mitigation measures include modifying the depths fished and soak times (Coelho et al., 2003; Mandelman et al., 2008; Afonso et al., 2011; Carruthers et al., 2011). 
Broadhurst et al. (2014) noted that a high proportion of hammerhead sharks were caught after sunrise, and suggested that setting lines only during the night could potentially reduce bycatch of this group. Determining the utility and efficacy of mitigation measures for any longline fishery clearly requires detailed investigations as to the likely impacts on target species, and improving handling practices may be one of the more pragmatic approaches to improving discard survival.

\section{PELAGIC TRAWLS AND PURSE SEINES}

There are few studies relating to the discard mortality in either pelagic trawl or purse seine fisheries. Some sharks predate on, or aggregate with, schooling teleosts, and so there is often a shark bycatch associated with fisheries for small pelagic fish. For example, De Silva et al. (2001) reported that $74 \%$ of sharks (Carcharhinidae and Sphyrnidae) taken in the Gulf of Mexico purse seine fishery for Gulf menhaden Brevoortia patronus

Goode 1878 were dead, with $12 \%$ disorientated on release, $8 \%$ released in a healthy condition and $6 \%$ of unknown fate.

Recent studies on $C$. falciformis taken as bycatch in purse seine fisheries for tuna reported AVM of $58.5-69 \%$ and, when considering post-release mortality through studies with PSATs, estimated overall mortality rates of $81-89 \%$ (Poisson et al., 2014a; Hutchinson et al., 2015; Eddy et al., 2016). The mortality of $C$. falciformis in these fisheries is influenced by various factors (Hutchinson et al., 2013, 2015; Eddy et al., 2016), including the size of the shark (smaller individuals showing higher mortality), total catch weight and the type of interaction with the gear (e.g. were they brailed or entangled in the netting). Some studies have undertaken control experiments by examining the mortality of line-caught fish (including free- 
swimming $C$. falciformis within the purse seine prior to brailing), with these fish generally surviving capture and release (Filmalter et al., 2013; Hutchinson et al., 2013). Modifications to fishing practices and handling practices could help reduce mortality of sharks in these fisheries, highlighting the need for collaborative research in bycatch mitigation (Poisson et al., 2014b).

Whilst RFMOs involved in tuna fisheries encourage purse seine vessels to avoid setting nets in areas where whale shark Rhincodon typus Smith 1828 are evident, this species may still be an occasional bycatch. Most specimens are generally released alive before the catch is brailed, and reported estimates of mortality (based on observer data where fate was recorded) are thought to be low (1.4\%; Capietto et al., 2014). Similarly, mobulid rays can survive capture and be released when brailed from the purse seine catch, although specimens entangled in the netting and then brought onboard often do not survive (Francis \& Jones, 2016).

Zeeberg et al. (2006) reported on the bycatch of sharks (including great hammerhead Sphyrna mokarran (Rüppell 1837), smooth hammerhead Sphyrna zygaena (Linnaeus 1758), S. lewini, Isurus spp., Carcharhinus spp., Alopias spp. and P. glauca) and giant manta Manta birostris (Walbaum 1792) associated with European industrial trawlers fishing off West Africa. Pelagic trawls were fitted with a 'filter grid', but Zeeberg et al. (2006) noted that "few animals arrive on deck alive and most suffocate and succumb to water pressure while caught in the filter grid". This study also summarised preliminary findings from incorporating an escape tunnel along the bottom of the trawl, which was suggested to have reduced elasmobranch bycatch.

RECREATIONAL FISHERIES 
There is a paucity of information on the discard survival of recreationally-caught elasmobranchs, both in European seas and elsewhere (McLoughlin \& Eliason, 2008). Mortality may be related to several factor, such as type and severity of hooking injury, fight time and handling practices (e.g. degree of care during hook removal and time on deck) and barometric and temperature differences (Gurshin \& Szedlmayer, 2004). Once again, demersal species with thick skins and buccal-pump ventilation may fair better than obligate ram-ventilators.

The potential impact of recreational fisheries on coastal elasmobranchs that are considered endangered has attracted some attention (e.g. Bansemer \& Bennett, 2010), and precautionary regulations to limit the types of recreational fishing (e.g. in terms of bait and trace) have even been established in some areas of Australia to reduce the likelihood of fishers catching protected shark species (Robbins et al., 2013).

To date, few studies have examined the PRM of elasmobranchs caught by recreational methods. Gurshin \& Szedlmayer (2004) tagged R. terraenovae $(\mathrm{n}=10)$ with self-releasing ultrasonic transmitters. These individuals were caught by hook-and-line, with retrieval and handling times of 2-6 mins and 1.5-7 mins, respectively (total duration of event 4-11.5 mins). One individual was thought to have died within an hour of release, but the remaining nine sharks were tracked for periods of $0.85-5.9 \mathrm{~h}$. The tracked fish exhibited higher rates of movement in the initial $1.5 \mathrm{~h}$, possibly reflecting post-release trauma. Danylchuk et al. (2014) captured juvenile lemon shark Negaprion brevirostris (Poey 1868) $(\mathrm{n}=32 ; 53-87.5 \mathrm{~cm} \mathrm{~L}$ ) on recreational gears (fight times of 43-476 sec.), and visually tracked these individuals for 0.25 $\mathrm{h}$ after release: four (12.5\%) individuals died in this short time frame.

In terms of larger sharks that may be taken in big-game fishing, French et al. (2015) examined the post-release mortality of $I$. oxyrinchus $(n=33 ; 110-265 \mathrm{~cm} \mathrm{~L}$ ) caught by recreational 
gears, using Pop-up Archival Transmitting tags. Fight times were up to $8.55 \mathrm{~h}$, but the majority ( $n=29$ ) were caught with fight times of $\leq 1 \mathrm{~h}$. Data were subsequently available for 30 individuals, of which only $10 \%$ died within 30 days.

Heberer et al. (2010) estimated 26\% PRM for A. vulpinus, with mortality increasing with fight time. Given that the specimens in this study were generally hooked in the caudal fin, which restricts forward movement, and so ram ventilation, this comparatively high mortality is unlikely to be typical for other sharks. A subsequent study compared the post-release mortality of $A$. vulpinus that were successfully tagged after hooking on the caudal fin $(\mathrm{n}=9$; 111-175 cm LF; 10-25 min fight time) or in the mouth ( $\mathrm{n}=7 ; 125-187 \mathrm{~cm} \mathrm{LF} ; 9-25 \mathrm{~min}$ fight time). Whilst all the latter survived for periods of $10-90$ days, individuals captured by the caudal fin showed low survival $(n=2 ; 22 \%)$, with six fish (66.7\%) dying in $\leq 5$ days and one fish showing mortality after 81 days (Sepulveda et al., 2015).

Rod-and-line caught $C$. taurus have also been found to have a high rate of survival, but individuals that swallowed the hook (gut-hooked) exhibited higher mortality rates (Kneebone et al., 2013).

\section{TAXONOMIC OVERVIEW OF ELASMOBRANCH DISCARD SURVIVAL}

Elasmobranch fish display a broad diversity in size, shape and skin structure, as well as their habitats (e.g. demersal, pelagic, deep-water) and respiratory mode (e.g. buccal-pump or ram ventilation). Consequently, there is a broad spectrum in the survival of elasmobranchs in relation to interactions with fishing gears. The following provides a synthesis of current knowledge on discard survival by order or, for the more species-rich orders, family. 


\section{HEXANCHIFORMES}

Very limited published data for European fisheries (Berrow, 1994; Megalofonou et al., 2003). Off the Bahamas, Brooks et al. (2015) noted that only $4.5 \%$ of Hexanchus spp. caught by scientific longline from waters of $500-790 \mathrm{~m}$ were dead, although the sample size $(n=22)$ was limited and soak times were $<4 \mathrm{~h}$. More data are available for broadnose sevengill shark Notorynchus cepedianus (Péron 1807) caught in Australian waters, with AVM of 33-83\% in gillnet fisheries (Walker et al., 2005; Braccini et al., 2012) and 85\% mortality of those taken in protective nets (Reid \& Krogh, 1992).

\section{SQUALIFORMES; FAMILY SQUALIDAE}

Studies in the North-west Atlantic have shown low AVM for trawl and line-caught S. acanthias, with 6-29\% mortality over the short-term (Mandelman \& Farrington, 2007a, b; Rulifson 2007). Soak times in these studies, however, were unlikely to be as used under normal commercial fishing operations. Reported levels of AVM for Squalus spp. caught by gillnet are: 0-6\% (Walker et al., 2005; mean soak time 8.2 h), 17.5\% (Rulifson, 2007, 19.5-23.5 h soak time), 22.5-38.5\% (Bendall et al., 2012; 11-27 h soak time) and 10-40\% (Braccini et al., 2012). Lyle et al. (2014) reported that AVM increased from 7\% (soak times $<8 \mathrm{~h}$ ) to $18 \%$ (overnight soak time), with an estimated $77-86 \%$ post-release survival. Cuban dogfish Squalus cubensis Howell Rivero 1936 caught by longline during scientific studies (4 h soak time), showed 9.1\% AVM, even though they were caught from depths of 472-730 m (Brooks et al., 2015). 


\section{SQUALIFORMES; FAMILIES CENTROPHORIDAE AND SOMNIOSIDAE}

Most squaliform sharks are deep-water species, and there are no published, quantified data on the AVM of commercially-caught deep-water sharks. Brooks et al. (2015) recorded the AVM of various deep-water sharks caught by longline off the Bahamas at depths down to about $1000 \mathrm{~m}$, but soak times were $<4 \mathrm{~h}$. Studies with electronic tags have indicated that leafscale gulper shark Centrophorus squamosus (Bonnaterre 1788), one of the deep-water shark species occurring in European seas, can survive after being caught by longline (2-3 $\mathrm{h}$ soak time) from waters of 900-1100 m (Rodríguez-Cabello \& Sánchez, 2014), but quantified data on the AVM and PRM of deep-water sharks that may be a bycatch in existing deep-water commercial fisheries are currently lacking.

\section{PRISTIOPHORIFORMES}

Sawsharks occur in the Indo-Pacific and parts of the Atlantic, but not in the North-east Atlantic. Walker et al. (2005) and Braccini et al. (2012) reported AVM of 7-42\% for the two species captured in Australian gillnet fisheries.

SQUATINIFORMES

Fennessy (1994) reported AVM of 60\% for African angel shark Squatina africana Regan 1908 caught in South African prawn trawlers, and AVM of $11-33 \%$ were reported for Australian 
angel shark Squatina australis Regan 1906 captured in gillnet fisheries with soak times <24 h (Walker et al., 2005; Braccini et al., 2012). The latter species is also captured occasionally in protective shark nets (soak times 12-48 h), where Reid \& Krogh (1992) reported that about $34 \%$ were dead. There are no quantitative data on the discard survival of angel sharks caught in fisheries in European waters.

\section{HETERODONTIFORMES}

Hornsharks, which are restricted to the Indo-Pacific, are an occasional bycatch in various demersal fisheries. Both Walker et al. (2005) and Braccini et al. (2012) reported a very low $\operatorname{AVM}(<1 \%)$ for those caught in an Australian gillnet fishery (soak times $<24 \mathrm{~h}$ ), with Reid \& Krogh (1992) noting that only 3.3\% were recovered dead from protective nets.

\section{ORECTOLOBIFORMES}

This order contains a diverse range of families, mostly occurring in tropical and sub-tropical seas, but there are few published studies relating to discard survival. Low AVM $(<10 \%)$ has been recorded for spotted wobbegong Orectolobus maculatus (Bonnaterre 1788) caught by gillnet (Walker et al., 2005; Braccini et al., 2012), with parascyllids exhibiting 12.5-20\% AVM in the same fishery. Carpet sharks Orectolobus spp. are also a bycatch in protective nets, and about $15 \%$ are recovered dead (Reid \& Krogh, 1992). Nurse shark Ginglymostoma cirratum (Bonnaterre 1788) is an occasional bycatch in inshore longline fisheries, although no AVM was 
observed by either Afonso et al. (2011) or Gulak et al. (2015). Likewise, no AVM of orectolobids was evident in demersal longline studies (Butcher et al., 2015).

\section{LAMNIFORMES; FAMILIES ODONTASPIDIDAE AND PSEUDOCARCHARIIDAE}

Three studies have provided estimates of AVM for members of the family Odontaspididae, ranging from $0 \%$ in demersal longline (Butcher et al., 2015; Gulak et al., 2015) to $41 \%$ in protective gillnets (Reid \& Krogh, 1992). Crocodile shark Pseudocarcharias kamoharai (Matsubara 1936) is a bycatch in offshore, pelagic longline fisheries, with a very broad range in reported AVM: 4.7-9.1\% (Fernandez-Carvalho et al., 2015); 13.3\% (Coelho et al., 2012); 38.7\% (Bromhead et al., 2012); 66.7\% (Musyl et al., 2011) and as high as 91\% (Afonso et al., 2012), although the latter study was based on a limited sample size.

\section{LAMNIFORMES; FAMILY ALOPIIDAE}

No published, quantitative data on the survival of Alopias spp. taken as bycatch in European trawl and set net fisheries, but data are available for European longline fisheries (e.g. Megalofonou et al., 2003). In general, Alopias spp. exhibit a relatively high mortality, with ca. 90\% recovered dead from protective nets (Reid \& Krogh, 1992) and reported AVM in gillnets of 60-66.7\%, even where soak times are relatively short (Walker et al., 2005; Braccini et al., 2012). Varying levels of mortality in pelagic longline fisheries have been reported in range of studies and, whilst a few studies have reported 'lower' estimates of 18-40\% AVM (Boggs, 1992; Musyl et al., 2011; Gilman et al., 2015), most studies have reported 48-68\% AVM 
(Beerkircher et al., 2004; Bromhead et al., 2012; Coelho et al., 2011, 2012; FernandezCarvalho et al., 2015). The higher AVM (89\%) reported by Afonso et al. (2012) was based on a small sample size.

\section{LAMNIFORMES; FAMILY LAMNIDAE}

Lamnids are fast-swimming pelagic sharks and whilst several species are a frequent catch in longline fisheries, these species can be an occasional bycatch in some gillnet fisheries and as an incidental catch in trawl fisheries. C. carcharias and I. oxyrinchus have been shown to exhibit 44\% and 37.5-75\% AVM in gillnet fisheries, respectively (Lyons et al., 2013; Walker et al., 2005; Braccini et al., 2012). Within European waters, L. nasus taken as a bycatch in bottom-set gillnets in the Celtic Sea have shown 80\% AVM (Bendall et al., 2012). Given the occasional (or seasonal) nature of such bycatch, these studies were all based on low sample sizes. Within the protective nets of Australia, $49 \%$ of $C$. carcharias and $91 \%$ of Isurus spp. were recovered dead (Reid \& Krough, 1993).

More data are available for longline fisheries, especially with regards $I$. oxyrinchus and $L$. nasus. Reported AVM of the former may be as low as ca. 5-30\% (Megalofonou et al. 2003; Epperly et al., 2012; Gallagher et al., 2014a; Gilman et al., 2015; Campana et al., 2016), but studies with greater sample sizes have generally reported AVM to be in the region of 35-56\% (Beerkircher et al., 2004; Coelho et al., 2011, 2012; Bromhead et al., 2012). These estimates of AVM are of a similar magnitude to that reported for L. nasus, 21-44\% (Coelho et al., 2012; Epperly et al., 2012; Gallagher et al., 2014a; Campana et al., 2016). Campana et al. (2016) also 
used PSATs to understand PRM, which allowed overall mortality to be estimated at 49 and 59\% for I. oxyrinchus and L. nasus, respectively.

\section{CARCHARHINIFORMES; FAMILY SCYLIORHINIDAE}

Catsharks are a frequent bycatch in demersal fisheries, and published estimates of AVM have ranged from <5\% (Kaiser \& Spencer, 1995; Walker et al., 2005; Braccini et al., 2012; Lyle et al., 2014) to $19.2 \%$ (Fennessy, 1994). In European waters, there have been three studies examining the short-term survival of $S$. canicula following capture, with survival rates ranging from 78-90\% in otter trawl (Rodríguez-Cabello et al., 2005), to 90-98\% survival in beam trawl (Kaiser \& Spencer, 1995; Revill et al., 2005). Whilst there are no comparable data for European gillnet fisheries, Lyle et al. (2014) reported 100\% survival of catsharks taken in Tasmanian gillnet fisheries ( $<24 \mathrm{~h}$ soak time). Scyliorhinids are generally regarded as robust to capture (Frick et al., 2009) and available data for shelf-living scyliorhinids indicate low AVM and low PRM. Many scyliorhinid species, however, occur in deeper water and data on the survival of deep-water scyliorhinids are lacking for European fisheries and limited for other parts of the world (Brooks et al., 2015).

\section{CARCHARHINIFORMES; FAMILIES TRIAKIDAE AND HEMIGALEIDAE}

Survival appears to be quite variable across this family, and published quantitative data are lacking for European species. Fennessy (1994) reported 29\% AVM for Arabian smooth-hound Mustelus mosis Hemprich \& Ehrenberg 1899 taken in the South African prawn trawl fishery, 
whilst the AVM of the sicklefin weasel shark Hemigaleus microstoma Bleeker 1852 was 62\% in the Australian prawn trawl fishery (Stobutzki et al., 2002). AVM ranged from 57-93\% for three triakid sharks taken in an Australian gillnet fishery, where the soak times were $<24 \mathrm{~h}$ (Braccini et al., 2012), which were comparable to earlier studies in this area (Walker et al., 2005). Whilst a lower AVM (24\%) was reported for M. antarcticus in Tasmanian gillnet fisheries, subsequent post-release survival was estimated at 58.7\% (Lyle et al., 2014), indicating that PRM is an important source of the overall mortality, in agreement with the experimental studies of Frick et al. (2010a). Lower AVM, of up to $25 \%$, has been reported for various triakid sharks captured by longline (Frick et al., 2010a; Coelho et al., 2012; Brooks et al., 2015; Butcher et al., 2015), but these data are either based on small sample sizes and/or from short soak times.

\section{CARCHARHINIFORMES; FAMILY CARCHARHINIDAE}

Those members of this family that occur in northern European seas are generally pelagic, although there are several more demersal species in sub-tropical and tropical waters. Overall, survival appears to be highly variable across this family (see Table II).

On one extreme, tiger shark Galeocerdo cuvier (Péron \& Lesueur 1822) is one of the more robust carcharhinid sharks, and multiple studies have indicated AVM of $<10 \%$ following capture by longline (Beerkircher et al., 2004; Morgan \& Burgess, 2007; Coelho et al., 2012; Gallagher et al., 2014a; Butcher et al., 2015; Gulak et al., 2015), with high post-release survival also reported (Afonso \& Hazin, 2014; Gallagher et al., 2014b). 
Similarly, P. glauca, which is a frequent bycatch of pelagic longline fisheries and one of the most studied pelagic sharks, typically exhibits an AVM of <25\% (Boggs, 1993; Megalofonou et al., 2003; Beerkircher et al., 2004; Moyes et al., 2006; Campana et al., 2009, 2011, 2016; Coelho et al., 2011, 2012; Musyl et al., 2011; Bromhead et al., 2012; Epperly et al., 2012; Serafy et al., 2012; Gallagher et al., 2014a; Gilman et al., 2015). There is, however, some postrelease mortality (see Campana et al., 2016) and some other field studies (e.g. Poisson et al., 2010; Afonso et al., 2012) have reported a higher AVM (30-50\%).

Several studies have reported AVM of $15-35 \%$ AVM for $C$. longimanus taken in longline fisheries (Boggs, 1993; Beerkircher et al., 2004; Bromhead et al., 2012; Coelho et al., 2012; Gallagher et al., 2014a; Fernandez Carvalho et al., 2015), with those studies reporting either a higher or lower AVM (Musyl et al., 2011; Poisson et al., 2010; Afonso et al., 2012) being based on more limited sample sizes.

In contrast to the above, other carcharhinids may be more prone to die during capture. Several studies have reported that night shark Carcharhinus signatus (Poey 1868) and C. falciformis exhibit higher AVM in relation to other members of the family taken in the same studies, ranging from $67-81 \%$ in the former and typically $42-75 \%$ in the latter (e.g. Beerkircher et al., 2004; Coelho et al., 2011, 2012; Serafy et al., 2012; Gallagher et al., 2014a). Interestingly, two studies have reported AVM of $C$. falciformis when caught by longline to be $<30 \%$ (Musyl et al., 2011; Gilman et al., 2015). C. falciformis is also bycatch in purse seine fisheries, where AVM and PRM can result in $>80 \%$ total mortality (Poisson et al., 2014a; Hutchinson et al., 2015; Eddy et al., 2016).

Most studies on members of this family have explored survival following capture by longline fisheries, with far fewer studies examining the impacts of other gears. Fennessy (1994) 
examined the survival of several species caught in a prawn trawl fishery and, of those species taken in meaningful numbers, AVM ranged from 29\% (Rhizoprionodon acutus (Rüppell 1837)) to $56 \%$ (Carcharhinus brevipinna (Müller \& Henle 1839)). The various carcharhinids taken in a prawn trawl fishery in Australian waters exhibited 52-82\% AVM (Stobutzki et al., 2002). Capture in scientific gillnets (soak times $\leq 1 \mathrm{~h}$ ) can result in AVM of $18-40 \%$ (Manire et al., 2001; Hueter et al., 2006). In relation to commercial gillnet fisheries, whilst some carcharhinids may be more robust (for example, 36\% AVM was reported for copper shark Carcharhinus brachyurus (Günther 1870) by Braccini et al. (2012)), higher AVM has been reported in other studies: $80.4-90.5 \%$ for three carcharhinid species (Thorpe \& Frierson, 2009), with $61-77 \%$ of two species of carcharhinid recovered dead from protective nets (Reid and Krogh, 1992).

\section{CARCHARHINIFORMES; FAMILY SPHYRNIDAE}

Hammerhead sharks appear to be particularly vulnerable to the effects of capture in commercial gears. High AVM for Sphyrna spp. has been reported in trawls (97.6\%; Fennessy, 1994), protective nets (98.3\%; Reid \& Krogh, 1992) and commercial gillnets (71.5-89.3\%; Thorpe \& Frierson, 2009; Braccini et al., 2012). Even capture in gillnets set for short periods ( $\leq 1 \mathrm{~h}$ ) during scientific studies can result in an AVM of 31-37\% (Manire et al., 2001; Hueter et al., 2006). Furthermore, estimates of overall mortality in the latter study, using markrecapture data from fish at different categories of vitality, suggested mortality of $62 \%$. Within commercial longline fisheries, though some studies have indicated AVM of $54-71 \%$ (Beerkircher et al., 2004; Coelho et al., 2012; Gallagher et al., 2014a; Fernandez-Carvalho, 
2015), higher estimates (AVM $=70-90 \%$ or more) have also been reported widely (Morgan \& Burgess, 2007; Coelho et al., 2011; Bromhead et al., 2012; Butcher et al., 2015). Afonso et al. (2011) noted a higher mortality when Sphyrna spp. were caught by J-hooks in comparison to circle hooks, but this was based on a low sample size. There have been fewer studies on PRM of hammerhead sharks. Gallagher et al. (2014b) noted that $43 \%$ of $S$. mokarran tagged were thought to have died within two weeks of release, despite the comparatively 'benign' capture technique (baited drum lines, 17-131 min fight times). Eddy et al. (2016) reported full PRM of S. lewini released after capture in tuna purse seine, but this was only based on tagging three specimens.

\section{PRISTIFORMES}

There are no published studies on the discard survival of sawfish. Given the scarcity of these species in many parts of their biogeographic range, most recent ecological studies have been from Florida and Australia. In such areas, they have been observed with fragments of monofilament around the rostrum (Seitz \& Poulakis, 2006), indicating that they may potentially survive interactions with fishing gear, although survival has not been quantified and the longer-term survival is unknown.

\section{RHINIFORMES AND RHINOBATIFORMES}

Guitarfish are a bycatch in various bottom fisheries, mostly in tropical and sub-tropical seas. Two species occur in southern European waters, but there are no data on their discard 
survival in this region. In South African waters, Fennessy (1994) provided data for four species from these closely-related orders, and whilst sample sizes were limited for individual species, aggregated data indicated AVM of $32.5 \%$ in trawl-caught specimens. Within Australian waters, Stobutzki et al. (2002) recorded 10\% AVM in a prawn trawl fishery, Walker et al. (2005) reported an AVM of $16.6 \%$ in a gillnet fishery, and AVM after capture on longline ranged from 0-25\%, depending on the time they were hooked for (Butcher et al., 2015).

\section{TORPEDINIFORMES}

Electric rays are an occasional bycatch in various bottom fisheries, mostly in tropical and subtropical seas. Three species occur in European waters, but there are no published data on the discard survival of these species. Indeed, discard data are very limited for this group, with a single study reporting AVM (40\%) for Gulf torpedo ray Torpedo sinuspersici Olfers 1831 in the South African prawn trawl fishery, albeit based on only five fish (Fennessy, 1994). Electric rays are generally considered to use their electric charge when in nets and, as it is possible that they are physiologically-impaired when discarded, studies on the PRM of members of this order could usefully be undertaken.

\section{RAJIFORMES}

Skates are a frequent bycatch, or even a target species-complex, in various demersal fisheries. Low AVM (<5\%) has been reported in $R$. clavata taken in various inshore fisheries, including longline, trawl and gillnet (Ellis et al., 2008b), and similarly low rates of AVM also reported for 
some other fisheries (Mandelman et al., 2013; Lyle et al., 2014; Saygu and Deval, 2014). AVM

is higher on more offshore grounds where tow durations and soak times are greater (e.g. Bendall et al., 2012), but there is less information from fisheries that catch skates from deeper water (but see Endicott \& Agnew, 2004; Laptikhovsky, 2004).

Studies using on-board survival tanks have shown survival of about $40-72 \%$ over various time periods, typically over 2-5 days (Kaiser \& Spencer, 1995; Laptikhovsky, 2004; Enever et al., 2009, 2010; Benoît et al., 2010a; Depestele et al., 2014), but some of these studies have combined data across the species-complex taken in the fishery and it should be recognised that there may be important species-specific differences in survival (Mandelman et al., 2013). Whilst there have been several ecological studies using electronic tags on skates, there have been no published studies using such technologies to better understand longer-term PRM of rajids.

\section{MYLIOBATIFORMES; FAMILIES DASYATIDAE AND UROLOPHIDAE}

Stingrays are a bycatch in various bottom fisheries, especially in tropical and sub-tropical seas. Various stingrays occur in European waters, including some demersal species and the pelagic $P$. violacea. Whilst there are extensive data on the AVM of the latter species, as it is taken in longline fisheries, the majority of stingrays are demersal and published data are more limited. Fennessy (1994) recorded four species from prawn trawl catches off South Africa, for which AVM ranged from $17.7-70 \%$ (34.6\% overall), and Stobutzki et al. (2002) found AVM of 5359\% for two species captured in an Australian prawn trawl fishery. Within gillnet fisheries, $>90 \%$ of dasyatids were found to be released alive when caught in shallow estuarine waters 
(Gray, 2002), with reported AVMs for urolophids ranging from $0 \%$ and up to $23 \%$ in various other gillnet fisheries (Walker et al., 2005; Braccini et al., 2012; Lyle et al., 2014). Both Afonso et al. (2011) and Butcher et al. (2015) conducted scientific studies with demersal longline, and reported that there was no AVM for those stingrays caught.

Pelagic longline fisheries can have a high bycatch of $P$. violacea, with estimates of AVM generally low: 1-10\% (Carruthers et al., 2009; Coelho et al., 2011, 2012; Afonso et al., 2012; Amorim et al., 2014), but ranging up to 10-30\% (Boggs, 1992; Bromhead et al., 2012; Gilman et al., 2015). Although Poisson et al. (2010) reported that nearly 59\% were dead, this study was based on a small sample size.

\section{MYLIOBATIFORMES; FAMILIES GYMNURIDAE, MYLIOBATIDAE AND MOBULIDAE}

Butterfly rays (Gymnuridae) have a sole representative in European waters, but there are no data on the discard survival when captured in European fisheries. Elsewhere in the world, reported AVM for members of this family ranges from 41-46\% (prawn trawl; Fennessy, 1994; Stobutzki et al., 2002).

Eagle rays (Myliobatidae) are only an infrequent bycatch in European fisheries, and this family is more diverse and abundant in warmer waters. Published data on members of this family have often been based on small sample sizes or have aggregated data at family-level. Estimates of AVM include $27 \%$ in prawn trawl (Fennessy, 1994; three species combined), 521\% in gillnet (Walker et al., 2005; Braccini et al., 2012). Coelho et al. (2012) did not record any AVM of members of this family caught by longline. 
Manta and devil rays (Mobulidae) are a bycatch in various pelagic fisheries in tropical and subtropical waters. Reported AVM ranges from about $1.4-5.2 \%$ for pelagic longline fisheries (Coelho et al., 2011, 2012; Mas et al., 2015), but there is potentially higher mortality in purse seine fisheries (Zeeberg et al., 2006; Croll et al., 2015), and improved estimates of both AVM and PRM are required for such fisheries. Francis \& Jones (2016) recently noted that spinetail devilray Mobula japanica (Müller \& Henle 1841) caught by purse seine and brought onboard by brail net could survive release $(n=3)$, although specimens entangled in the netting when brought on board $(n=4)$ did not survive release.

\section{CONCLUSIONS AND FUTURE DIRECTIONS}

There has been increased management interest in elasmobranch fish in recent decades, and consequently there has been a notable increase in discard survival studies over the last ten years. This is highlighted by the fact that the review by Broadhurst et al. (2006) cited only three studies that quantified estimates of the mortality (AVM or PRM) of elasmobranchs captured in towed commercial gears. Whilst there have been numerous studies examining the AVM of elasmobranchs captured in various longline fisheries (primarily pelagic longline fisheries for tuna and tuna-like species, with these data often collected during observer programmes), data on AVM for many other fisheries are typically very limited. Improved international-coordination to collect standardised data on AVM for other fisheries could usefully be considered.

The various studies that have collected data on the vitality of fish after capture have used a range of scales, ranging from 5-point scales to a simpler binary (live or dead) scoring system. Those studies using 3-5 point scales have generally defined how the categories are selected 
(e.g. based on the degree of body movements, spiracular movements and body damage), but the application of these in the field may be somewhat more subjective in more extensive observer programmes. Whilst more categories can provide valuable data for any individual study, an increased number of categories could result in observer-related differences in more extensive data collection programmes. Hence, studies to examine the extent of betweenobserver variation and to better determine an optimal scoring system for the collection of vitality and AVM data for multi-observer field programmes are required.

Whilst there have been an increased number of published studies on AVM, there is still a paucity of data on PRM, with existing studies based typically on short-term survival in tanks or cages (e.g. Rodríguez-Cabello et al., 2005; Mandelman \& Farrington, 2007b; Lyle et al., 2014), or from using electronic tags (e.g. Gallagher et al., 2014b; Campana et al., 2016). Whilst the former may be suitable for smaller-bodied elasmobranchs, including juveniles, the potential effects of captive stress should always be addressed where possible. There has been an increased use of electronic tags to better understand and quantify PRM, especially for larger pelagic sharks, but improved coordination of such studies could be considered, given the resources required to provide robust estimates based on appropriate sample sizes.

Data on various facets of the survival of elasmobranchs are now available for both a range of taxa and fisheries. The identification of data gaps and the prioritisation of data requirements should be undertaken by RFMOs, or other competent bodies, in order to identify where there are significant discarding issues, with particular reference to the discarding of (a) species that are prohibited or not to be retained; (b) discarding of unmarketable bycatch species, especially if the discarded species are considered vulnerable taxa; (c) discarding of small individuals (which may be either regulatory discarding, if a minimum landings size is enforced, 
or economic discarding that is influenced by low market value of smaller-sized fish); and (d) regulatory discarding (e.g. when a quota is enforced and is set at a restrictive level), which can include the discarding of larger fish of marketable size. Whilst such analyses are required for many fish and shellfish, specific analyses for elasmobranchs (and other vulnerable taxa) should be considered.

Within European waters, several elasmobranch stocks, including rajiform skates and spurdog, will potentially be included within the landing obligation, unless there is an appropriate body of scientific evidence to demonstrate high survival. In relation to spurdog, limited data on AVM are available for gillnet capture (Bendall et al., 2012), but these were derived mostly from sets with reduced soak time and so are expected to give higher estimates of survival than may be expected under normal fishing operations. Other published studies to date have been from field studies undertaken elsewhere in the world (Rulifson, 2007; Mandelman \& Farrington, 2007a, b; Braccini et al., 2012; Lyle et al., 2014), but these studies will not reflect the range of fishing operations catching spurdog in European seas.

There have been several studies examining 'discard survival' of skates, both in European seas (Kaiser \& Spencer, 1995; Ellis et al., 2008b; Enever et al., 2009, 2010; Bendall et al., 2012; Depestele et al., 2014) and elsewhere (Fennessy, 1994; Endicott \& Agnew, 2004; Laptikhovsky, 2004; Benoît et al., 2010a, b, 2012; Mandelman et al., 2013; Lyle et al., 2014; Saygu \& Deval, 2014). Whilst providing data on AVM and short-term survival, there are currently no published quantitative estimates of longer-term PRM. Hence, robust, quantitative estimates of survival are required for a variety of elasmobranchs captured in various European fisheries. 
Fisheries managers are increasingly using lists of prohibited species to reduce fishing mortality on the most vulnerable taxa that may be captured in fisheries. Whilst such measures will prevent fisheries legally targeting such species, the overall efficacy of such listings is dependent on whether fisheries have a reduced encounter rate (i.e. they do not fish in any areas where prohibited species occur regularly or in higher abundance) and whether or not there is a low mortality (including AVM and PRM). Hence, improved studies to better understand the AVM and PRM of prohibited species is required in order to determine whether a prohibited listing alone will reduce fishing mortality or whether other measures (e.g. gear modifications, improved catch processing and handling, or spatial management) are also required. Whilst species that are prohibited in European fisheries are exempt from the landing obligation, there is still a scientific need to understand the degree of discard survival of such species.

Fisheries management has traditionally tried to afford protection of juvenile fish, whether through spatial management (e.g. closures or gear restrictions in nursery grounds), or through a minimum landing size). Additionally, smaller fish are often of lower market value, and so may be more likely to be discarded by fishers. Some studies have confirmed that smaller fish may display higher capture mortality (Diaz \& Serafy, 2005; Ellis et al., 2008b) and smaller individuals are intuitively more likely to be predated on by scavengers following discarding. Hence, further studies to better identify the discarding levels, AVM and PRM of juvenile elasmobranchs are required, especially in relation to trawl and dredge fisheries which can have a relatively higher bycatch of juveniles.

Several studies have indicated that females of some elasmobranch species may survive better than males (e.g. Stobutzki et al., 2002; Laptikhovsky, 2004). This may be linked to females 
having a thicker skin, although the increased thickness of the skin in females has only been established for very few species (Pratt, 1979; Kajiura et al., 2000). It can also be noted that elasmobranchs often display a sexual dimorphism in maximum size (females attaining a larger size) and fecundity generally increases with length. Maximum landing lengths for elasmobranchs have been used as management measures in some areas, in order to reduce fishing mortality on the female spawning stock. Quantifying potential sex-based (and sizebased) differences in AVM and PRM could provide important data to inform the relative merits of the various options for size restrictions that might be considered. Another area that has not been subject to meaningful study is the chances of near-term females giving birth to their young successfully, even if PRM of the mother could be high. Several studies have shown that females may birth their young (including term pups, but also mid-term embryos) on capture (e.g. Trinnie et al., 2012), and this is widely presumed to be stress-related. Dissection of dead S. acanthias and other sharks shortly after capture can even allow live pups to be removed from the uteri (J. R. Ellis, pers. obs.). For some species, there may need to be due consideration of the potential for gravid females to give birth after discarding, even if the mother has a low chance of longer-term survival, and how this should be considered under any landing obligations.

Some published studies have combined data across families, in order to maximise sample sizes. Some of the more species-rich families (e.g. Carcharhinidae and Rajidae), however, can have differing levels of AVM despite their morphological and ecological similarities. Hence, future studies should endeavour to provide species-specific data on AVM wherever possible, even if more detailed analyses use aggregated data. 
Certain elasmobranch taxa, including Sphyrna spp. and Alopias spp., are of particular concern to some RFMOs, and these species are identified as species that should not be retained in some fisheries. Studies to date have generally indicated that AVM and/or PRM of both Sphyrna spp. and Alopias spp. can be higher than observed in other elasmobranch taxa taken in the same fisheries. Further studies to identify what modifications to fishing gears, fishing practices and handling may successfully improve the survivorship of such taxa are required.

\section{Acknowledgements}

This work was supported by the Department of Environment, Food and Rural Affairs (DEFRA; projects MA011, MA016, MB5201, MB5202 and MF6001). Additional thanks to Gary Burt, Tom Catchpole and Joana Silva for their input, and the Associate Editor and reviewers for their comments. 


\section{References}

Adams, D. H., Borucinska, J. D., Maillett, K., Whitburn, K. \& Sander, T. E. (2015). Mortality due to a retained circle hook in a longfin mako shark Isurus paucus (Guitart-Manday). Journal of Fish Diseases 38, 621-628.

Afonso, A. S. \& Hazin, F. H. (2014). Post-release survival and behavior and exposure to fisheries in juvenile tiger sharks, Galeocerdo cuvier, from the South Atlantic. Journal of Experimental Marine Biology and Ecology 454, 55-62.

Afonso, A. S., Hazin, F. H., Carvalho, F., Pacheco, J. C., Hazin, H., Kerstetter, D. W., Murie, D. \& Burgess, G. H. (2011). Fishing gear modifications to reduce elasmobranch mortality in pelagic and bottom longline fisheries off Northeast Brazil. Fisheries Research 108, 336-343.

Afonso, A. S., Santiago, R., Hazin, H. \& Hazin, F. H. (2012). Shark bycatch and mortality and hook bite-offs in pelagic longlines: interactions between hook types and leader materials. Fisheries Research 131-133, 9-14.

Amorim, S., Santos, M. N., Coelho, R. \& Fernandez-Carvalho, J. (2015). Effects of 17/0 circle hooks and bait on fish catches in a Southern Atlantic swordfish longline fishery. Aquatic Conservation: Marine and Freshwater Ecosystems 25, 518-533.

Baeta, F., Batista, M., Maia, A., Costa, M. J. \& Cabral, H. (2010). Elasmobranch bycatch in a trammel net fishery in the Portuguese west coast. Fisheries Research 102, 123-129.

Bansemer, C. S. \& Bennett, M. B. (2010). Retained fishing gear and associated injuries in the east Australian grey nurse sharks (Carcharias taurus): implications for population recovery. Marine and Freshwater Research 61, 97-103.

Beardsall, J. W., McLean, M. F., Cooke, S. J., Wilson, B. C., Dadswell, M. J., Redden, A. M. \& Stokesbury, M. J. (2013). Consequences of incidental otter trawl capture on survival and physiological condition of threatened Atlantic sturgeon. Transactions of the American Fisheries Society 142, 1202-1214.

Beerkircher, L. R., Cortés, E. \& Shivji, M. (2004). Characteristics of shark bycatch observed on pelagic longlines off the southeastern United States, 1992-2000. Marine Fisheries Review $64,40-49$. 
Belcher, C. N. \& Jennings, C. A. (2011). Identification and evaluation of shark bycatch in Georgia's commercial shrimp trawl fishery with implications for management. Fisheries Management and Ecology 18, 104-112.

Benjamins, S., Kulka, D. W. \& Lawson, J. (2010). Recent incidental catch of sharks in gillnet fisheries of Newfoundland and Labrador, Canada. Endangered Species Research 11, 133146.

Benoît, H. P., Hurlbut, T. \& Chassé, J. (2010a). Assessing the factors influencing discard mortality of demersal fishes using a semi-quantitative indicator of survival potential. Fisheries Research 106, 436-447.

Benoît, H. P., Hurlbut, T., Chassé, J. \& Jonsen, I. D. (2012). Estimating fishery-scale rates of discard mortality using conditional reasoning. Fisheries Research 125, 318-330.

Benoît, H. P., Plante, S., Kroiz, M. \& Hurlbut, T. (2013). A comparative analysis of marine fish species susceptibilities to discard mortality: effects of environmental factors, individual traits, and phylogeny. ICES Journal of Marine Science 70, 99-113.

Berrow, S. D. (1994). Incidental capture of elasmobranchs in the bottom-set gill-net fishery off the south coast of Ireland. Journal of the Marine Biological Association of the United Kingdom 74, 837-847.

Boggs, C. H. (1992). Depth, capture time and hooked longevity of longline-caught pelagic fishtiming bites of fish with chips. Fishery Bulletin 90, 642-658.

Borges, T. C., Erzini, K., Bentes, L., Costa, M. E., Gonçalves, J. M. S., Lino, P. G., Pais, C. \& Ribeiro, J. (2001). By-catch and discarding practices in five Algarve (southern Portugal) métiers. Journal of Applied Ichthyology 17, 104-114.

Borucinska, J., Kohler, N., Natanson, L. \& Skomal, G. (2002). Pathology associated with retained fishing hooks in blue sharks, Prionace glauca (L.), with implications for their conservation. Journal of Fish Diseases 25, 515-521.

Braccini, M., Van Rijn, J. \& Frick, L. (2012). High post-capture survival for sharks, rays and chimaeras discarded in the main shark fishery of Australia? PloS One 7(2), e32547, 1-9. 
Brewer, D., Heales, D., Milton, D., Dell, Q., Fry, G., Venables, B. \& Jones, P. (2006). The impact of turtle excluder devices and bycatch reduction devices on diverse tropical marine communities in Australia's northern prawn trawl fishery. Fisheries Research 81, 176-188.

Brill, R., Bushnell, P., Schroff, S., Seifert, R. \& Galvin, M. (2008). Effects of anaerobic exercise accompanying catch-and-release fishing on blood-oxygen affinity of the sandbar shark (Carcharhinus plumbeus, Nardo). Journal of Experimental Marine Biology and Ecology 354, $132-143$.

Broadhurst, M. K., Butcher, P. A., Millar, R. B., Marshall, J. E. \& Peddemors, V. M. (2014). Temporal hooking variability among sharks on south-eastern Australian demersal longlines and implications for their management. Global Ecology and Conservation 2, 181-189.

Broadhurst, M. K., Suuronen P. \& Hulme, A. (2006). Estimating collateral mortality from towed fishing gear. Fish and Fisheries 7, 180-218.

Bromhead, D., Clarke, S. Hoyle, S., Muller, B., Sharples, P. \& Harley, S. (2012). Identification of factors influencing shark catch and mortality in the Marshall Islands tuna longline fishery and management implications. Journal of Fish Biology 80, 1870-1894.

Brooks, E. J., Brooks, A. M., Williams, S., Jordan, L. K., Abercrombie, D., Chapman, D. D., Howey-Jordan, L. A. \& Grubbs, R. D. (2015). First description of deep-water elasmobranch assemblages in the Exuma Sound, The Bahamas. Deep Sea Research Part II: Topical Studies in Oceanography 115, 81-91.

Brooks, E. J., Mandelman, J. W., Sloman, K. A., Liss, S., Danylchuk, A. J., Cooke, S. J., Skomal, G. B., Phillip, D. P., Sims, D. W. \& Suski, C. D. (2012). The physiological response of the Caribbean reef shark (Carcharhinus perezi) to longline capture. Comparative Biochemistry and Physiology (Part A) 162, 94-100.

Brunnschweiler, J. M., Nielsen, F. \& Motta, P. (2011). In situ observation of stomach eversion in a line-caught Shortfin Mako (Isurus oxyrinchus). Fisheries Research 109, 212-216.

Butcher, P. A., Peddemors, V. M., Mandelman, J. W., McGrath, S. P. \& Cullis, B. R. (2015). Atvessel mortality and blood biochemical status of elasmobranchs caught in an Australian commercial longline fishery. Global Ecology and Conservation 3, 878-889. 
Campana, S. E., Joyce, W., Fowler, M. \& Showell, M. (2016). Discards, hooking, and postrelease mortality of porbeagle (Lamna nasus), shortfin mako (Isurus oxyrinchus), and blue shark (Prionace glauca) in the Canadian pelagic longline fishery. ICES Journal of Marine Science 73, 520-528.

Campana, S. E., Joyce, W. \& Manning, M. J. (2009a). Bycatch and discard mortality in commercially caught blue sharks Prionace glauca assessed using archival satellite popup tags. Marine Ecology Progress Series 387,241-253.

Campana, S. E., Joyce, W., Francis, M. P. \& Manning, M. J. (2009b). Comparability of blue shark mortality estimates for the Atlantic and Pacific longline fisheries. Marine Ecology Progress Series 396, 161-164.

Capietto, A., Escalle, L., Chavance, P., Dubroca, L., Delgado de Molina, A., Murua, H., Floch, L., Damiano, A., Rowar, D., Merigot, B. (2014). Mortality of marine megafauna induced by fisheries: Insights from the whale shark, the world's largest fish. Biological Conservation 174, 147-151.

Carruthers, E. H., Neilson, J. D. \& Smith, S. C. (2011). Overlooked bycatch mitigation opportunities in pelagic longline fisheries: Soak time and temperature effects on swordfish (Xiphias gladius) and blue shark (Prionace glauca) catch. Fisheries Research 108, 112-120.

Carruthers, E. H., Schneider, D. C. \& Neilson, J. D. (2009). Estimating the odds of survival and identifying mitigation opportunities for common bycatch in pelagic longline fisheries. Biological Conservation 142, 2620-2630.

Chin, A., Mourier, J. \& Rummer, J. L. (2015). Blacktip reef sharks (Carcharhinus melanopterus) show high capacity for wound healing and recovery following injury. Conservation physiology 3(1), cov062.

Chopin, F. S. \& Arimoto, T. (1995). The condition of fish escaping from fishing gears - a review. Fisheries Research 21, 315-327.

Chosid, D. M., Pol, M., Szymanski, M., Mirarchi, F. \& Mirarchi, A. (2012). Development and observations of a spiny dogfish Squalus acanthias reduction device in a raised footrope silver hake Merluccius bilinearis trawl. Fisheries Research 114, 66-75. 
Cicia, A. M., Schlenker, L. S., Sulikowski, J. A. \& Mandelman, J. W. (2012). Seasonal variations in the physiological stress response to discrete bouts of aerial exposure in the little skate, Leucoraja erinacea. Comparative Biochemistry and Physiology (Part A) 162, 130-138.

Coelho, R., Bentes, L., Gonçalves, J., Lino, P. G., Ribeiro, J. \& Erzini, K. (2003). Reduction of elasmobranch by-catch in the hake semipelagic near-bottom longline fishery in the Algarve (Southern Portugal). Fisheries Science 69, 293-299.

Coelho, R., Fernandez-Carvalho, J., Lino, P. G. \& Santos, M. N. (2012). An overview of the hooking mortality of elasmobranchs caught in a swordfish pelagic longline fishery in the Atlantic Ocean. Aquatic Living Resources 25, 311-319.

Coelho, R., Infante, P. \& Santos, M. N. (2013). Application of generalized linear models and generalized estimation equations to model at-haulback mortality of blue sharks captured in a pelagic longline fishery in the Atlantic Ocean. Fisheries Research 145, 66-75.

Craven, H. R., Brand, A. R. \& Stewart, B. D. (2013). Patterns and impacts of fish bycatch in a scallop dredge fishery. Aquatic Conservation: Marine and Freshwater Ecosystems 23, 152170.

Croll, D. A., Dewar, H., Dulvy, N. K., Fernando, D., Francis, M. P., Galván-Magaña, F., Hall, M., Heinrichs, S., Marshall, A., Mccauley, D., Newton, K. M., Notarbartolo-Di-Sciara, G., O'Malley, M., O'Sullivan, J., Poortvliet, M., Roman, M., Stevens, G., Tershy, B. R. \& White, W. T. (2015) Vulnerabilities and fisheries impacts: the uncertain future of manta and devil rays. Aquatic Conservation: Marine and Freshwater Ecosystems DOI: 10.1002/aqc.2591

Crow, G. L., Howe, J. C., Uchida, S., Kamolnick, S., Wisner, M. G. \& Caira, J. N. 1990. Protrusion of the valvular intestine through the cloaca in sharks of the family Carcharhinidae. Copeia $1990,226-229$.

Danylchuk, A. J., Suski, C. D., Mandelman, J. W., Murchie, K. J., Haak, C. R., Brooks, A. M. \& Cooke, S. J. (2014). Hooking injury, physiological status and short-term mortality of juvenile lemon sharks (Negaprion bevirostris) following catch-and-release recreational angling. Conservation Physiology 2, 1-10. 
Dapp, D. R., Huveneers, C., Walker, T. I., Drew, M. \& Reina, R. D. (2016). Moving from measuring to predicting bycatch mortality: predicting the capture condition of a longlinecaught pelagic shark. Frontiers in Marine Science 2, 126, 10 pp.

Dapp, D. R., Walker, T. I., Huveneers, C. \& Reina, R. D. (2015). Respiratory mode and gear type are important determinants of elasmobranch immediate and post-release mortality. Fish and Fisheries, in press. doi: 10.1111/faf.12124

Davis, M. W. (2002). Key principles for understanding fish bycatch discard mortality. Canadian Journal of Fisheries and Aquatic Sciences 59, 1834-1843.

Depestele, J., Desender, M., Benoît, H. P., Polet, H. \& Vincx, M. (2014). Short-term survival of discarded target fish and non-target invertebrate species in the "eurocutter" beam trawl fishery of the southern North Sea. Fisheries Research 154, 82-92.

De Silva, J. A., Condrey, R. E. \& Thompson, B. A. (2001). Profile of shark bycatch in the U.S. Gulf of Mexico menhaden fishery. North American Journal of Fisheries Management 21, 111-124.

Diaz, G. A. \& Serafy, J. E. (2005). Longline-caught blue shark (Prionace glauca): factors affecting the numbers available for live release. Fishery Bulletin 103, 720-724.

Eddy, C., Brill, R. \& Bernal, D. (2016). Rates of at-vessel mortality and post-release survival of pelagic sharks captured with tuna purse seines around drifting fish aggregating devices (FADs) in the equatorial eastern Pacific Ocean. Fisheries Research 174, 109-117.

Ellis, J. R., Clarke, M. W., Cortés, E., Heessen, H. J. L., Apostolaki, P., Carlson, J. K. \& Kulka, D. W. (2008a). Management of elasmobranch fisheries in the North Atlantic. In Advances in Fisheries Science. 50 years on from Beverton and Holt (A.I.L. Payne, A.J. Cotter and E.C.E. Potter, eds.), pp. 184-228. Blackwell Publishing, Oxford. xxi + 547 pp.

Endicott, M. \& Agnew, D. J. (2004). The survivorship of rays discarded from the South Georgia longline fishery. CCAMLR Science 11, 155-164.

Enever, R., Catchpole, T. L., Ellis, J. R. \& Grant, A. (2009). The survival of skates (Rajidae) caught by demersal trawlers fishing in UK waters. Fisheries Research 97, 72-76.

Enever, R., Revill, A. S., Caslake, R. \& Grant, A. (2010). Discard mitigation increases skate survival in the Bristol Channel. Fisheries Research 102, 9-15. 
Epperly, S. P., Watson, J. W., Foster, D. G. \& Shah, A. K. (2012). Anatomical hooking location and condition of animals captured with pelagic longlines: the grand banks experiments 2002-2003. Bulletin of Marine Science 88, 513-527.

Favaro, B. \& Côté, I. M. (2015). Do by-catch reduction devices in longline fisheries reduce capture of sharks and rays? A global meta-analysis. Fish and Fisheries 16, 300-309.

Fennessy, S. T. (1994). Incidental capture of elasmobranchs by commercial prawn trawlers on the Tugela Bank, Natal, South Africa. South African Journal of Marine Science 14, 287-296.

Fernandez-Carvalho, J., Coelho, R., Santos, M. N. \& Amorim, S. (2015). Effects of hook and bait in a tropical northeast Atlantic pelagic longline fishery: Part II-Target, bycatch and discard fishes. Fisheries Research 164, 312-321.

Filmalter, J. D., Capello, M., Deneubourg, J. L., Cowley, P. D. \& Dagorn, L. (2013). Looking behind the curtain: quantifying massive shark mortality in fish aggregating devices. Frontiers in Ecology and the Environment 11, 291-296.

Francis, M. P., Griggs, L. H. \& Baird, S. J. (2001). Pelagic shark bycatch in the New Zealand tuna longline fishery. Marine and Freshwater Research 52, 165-178.

Francis, M. P. \& Jones, E. G. (2016). Movement, depth distribution and survival of spinetail devilrays (Mobula japanica) tagged and released from purse-seine catches in New Zealand. Aquatic Conservation: Marine and Freshwater Ecosystems doi: 10.1002/aqc.2641.

French, R. P., Lyle, J., Tracey, S., Currie, S. \& Semmens, J. M. (2015). High survivorship after catch-and-release fishing suggests physiological resilience in the endothermic shortfin mako shark (Isurus oxyrinchus). Conservation Physiology 3: doi:10.1093/conphys/cov044.

Frick, L. H., Reina, R. D. \& Walker, T. I. (2009) The physiological response of Port Jackson sharks and Australian swellsharks to sedation, gill-net capture, and repeated sampling in captivity. North American Journal of Fisheries Management 29, 127-139.

Frick, L. H., Reina, R. D. \& Walker, T. I. (2010a) Stress related changes and post-release survival of Port Jackson sharks (Heterodontus portusjacksoni) and gummy sharks (Mustelus antarcticus) following gill-net and longline capture in captivity. Journal of Experimental Marine Biology and Ecology 385, 29-37. 
Frick, L. H., Walker, T. I. \& Reina, R. D. (2010b) Trawl capture of Port Jackson sharks, Heterodontus portusjacksoni, and gummy sharks, Mustelus antarcticus, in a controlled setting: Effects of tow duration, air exposure and crowding. Fisheries Research 6, 344-350.

Frick, L. H., Walker, T. I. \& Reina, R. D. (2012). Immediate and delayed effects of gill-net capture on acid-base balance and intramuscular lactate concentration of gummy sharks, Mustelus antarcticus. Comparative Biochemistry and Physiology (Part A) 162, 88-93.

Gallagher, A. J., Orbesen, E. S., Hammerschlag, N. \& Serafy, J. E. (2014a). Vulnerability of oceanic sharks as pelagic longline bycatch. Global Ecology and Conservation 1, 50-59.

Gallagher, A. J., Serafy, J. E., Cooke, S. J. \& Hammerschlag, N. (2014b). Physiological stress response, reflex impairment, and survival of five sympatric shark species following experimental capture and release. Marine Ecology Progress Series 496, 207-218.

García-Caudillo, J. M., Cisneros-Mata, M. A. \& Balmori-Ramírez, A. (2000). Performance of a bycatch reduction device in the shrimp fishery of the Gulf of California, Mexico. Biological Conservation 92, 199-205.

Gilman, E., Chaloupka, M., Merrifield, M., Malsol, N. D. \& Cook, C. (2015). Standardized catch and survival rates, and effect of a ban on shark retention, Palau pelagic longline fishery. Aquatic Conservation: Marine and Freshwater Ecosystems, in press

Gilman, E., Clarke, S., Brothers, N., Alfaro-Shigueto, J., Mandelman, J., Mangel, J., Petersen, S., Piovano, S., Thomson, N., Dalzell, P., Donoso, M., Goren, M. \& Werner, T. (2008). Shark interactions in pelagic longline fisheries. Marine Policy 32, 1-18.

Godin, A.C., Carlson, J.K. \& Burgener, V. (2012). The effect of circle hooks on shark catchability and at-vessel mortality rates in longline fisheries. Bulletin of Marine Science 88, 469-483.

Gray, C. A. (2002). Management implications of discarding in an estuarine multi-species gill net fishery. Fisheries Research 56, 177-192.

Griffiths, S. P., Brewer, D. T., Heales, D. S., Milton, D. A. \& Stobutzki, I. C. (2006). Validating ecological risk assessments for fisheries: assessing the impacts of turtle excluder devices on elasmobranch bycatch populations in an Australian trawl fishery. Marine and Freshwater Research 57, 395-401. 
Gruber, S. H., de Marignac, J. R. C. \& Hoenig, J. M. (2001). Survival of juvenile lemon sharks at Bimini, Bahamas, estimated by mark-depletion experiments. Transactions of the American Fisheries Society 130, 376-384.

Guida, L., Walker, T. I. \& Reina, R. D. (2016a). The adenylate energy charge as a new and useful indicator of capture stress in chondrichthyans. Journal of Comparative Physiology B 186, 193-204.

Guida, L., Walker, T. I. \& Reina, R. D. (2016b). Temperature insensitivity and behavioural reduction of the Physiological stress response to longline capture by the gummy shark, Mustelus antarcticus. PLOS ONE 11(2): e0148829.

Gulak, S. J. B., de Ron Santiago, A. J. \& Carlson, J. K. (2015). Hooking mortality of scalloped hammerhead Sphyrna lewini and great hammerhead Sphyrna mokarran sharks caught on bottom longlines. African Journal of Marine Science 37, 267-273.

Gurshin, C. W. D. \& Szedlmayer, S. T. (2004). Short-term survival and movements of Atlantic sharpnose sharks captured by hook-and-line in the north-east Gulf of Mexico. Journal of Fish Biology 65, 973-986.

Hammerschlag, N., Gallagher, A. J. \& Lazarre, D. M. (2011). A review of shark satellite tagging studies. Journal of Experimental Marine Biology and Ecology 398, 1-8.

He, P. (2006). Effect of the headline height of gillnets on species selectivity in the Gulf of Maine. Fisheries Research 78, 252-256.

Heard, M., Van Rijn, J. A., Reina, R. D. \& Huveneers, C. (2014). Impacts of crowding, trawl duration and air exposure on the physiology of stingarees (family: Urolophidae). Conservation Physiology 2, 1-14.

Heberer, C., Aalbers, S. A., Bernal, D., Kohin, S., DiFiore, B. \& Sepulveda, C. A. (2010). Insights into catch-and-release survivorship and stress-induced blood biochemistry of common thresher sharks (Alopias vulpinus) captured in the southern California recreational fishery. Fisheries Research 106, 495-500.

Hight, B. V., Holts, D., Graham, J. B., Kennedy, B. P., Taylor, V., Sepulveda, C. A., Bernal, D., Ramon, D., Rasmussen, R. \& Chin Lai, N. (2007). Plasma catecholamine levels as indicators 
of the post-release survivorship of juvenile pelagic sharks caught on experimental drift longlines in the Southern California Bight. Marine Freshwater Research 58, 145-151.

Hoffmayer, E. R., Hendon, J. M. \& Parsons, G. R. (2012). Seasonal modulation in the secondary stress response of a carcharhinid shark, Rhizoprionodon terraenovae. Comparative Biochemistry and Physiology (Part A) 162, 81-87.

Hoffmayer, E. R. \& Parsons, G. R. (2001). The physiological response to capture and handling stress in the Atlantic sharpnose shark, Rhizoprionodon terraenovae. Fish Physiology and Biochemistry 25, 277-285.

Hoolihan, J. P., Luo, J. G., Abascal, F. J., Campana, S. E., De Metrio, G., Dewar, H., Domeier, M. L., Howey, L. A., Lutcavage, M. E., Musyl, M. K., Neilson, J. D., Orbesen, E. S., Prince, E. D. \& Rooker, J. R. (2011). Evaluating post-release behaviour modification in large pelagic fish deployed with pop-up satellite archival tags. ICES Journal of Marine Science $68,880-889$.

Hueter, R. E., Manire, C. A., Tyminski, J. P., Hoenig, J. M. \& Hepworth, D. A. (2006). Assessing mortality of released or discarded fish using a logistic model of relative survival derived from tagging data. Transactions of the American Fisheries Society 135, 500-508.

Hutchinson, M. R., Itano, D. G., Muir, J. A. \& Holland, K. N. (2015). Post-release survival of juvenile silky sharks captured in a tropical tuna purse seine fishery. Marine Ecology Progress Series 521, 143-154.

Hyatt, M. W., Anderson, P. A., O'Donnell, P. M. \& Berzins, I. K. (2012). Assessment of acidbase derangements among bonnethead (Sphyrna tiburo), bull (Carcharhinus leucas), and lemon (Negaprion brevirostris) sharks from gillnet and longline capture and handling methods. Comparative Biochemistry and Physiology (Part A), 162, 113-120.

Hyatt, M. W., Anderson, P. A. \& O'Donnell, P. M. (2016). Behavioral release condition score of bull and bonnethead sharks as a coarse indicator of stress. Journal of Coastal Research; doi: http://dx.doi.org/10.2112/JCOASTRES-D-15-00108.1

Isaksen, B., Valdemarsen, J., Larsen, R. \& Karlsen, L. (1992). Reduction of fish by-catch in shrimp trawl using a rigid separator grid in the aft belly. Fisheries Research 13, 335-352. 
Jaiteh, V. F., Allen, S. J., Meeuwig, J. J. \& Loneragan, N. R. (2014). Combining in-trawl video with observer coverage improves understanding of protected and vulnerable species bycatch in trawl fisheries. Marine and Freshwater Research 65, 830-837

Jordan, L. K., Mandelman, J. W., McComb, D. M., Fordham, S. V., Carlson, J. K. \& Werner, T. B. (2013). Linking sensory biology and fisheries bycatch reduction in elasmobranch fishes: a review with new directions for research. Conservation Physiology 1, doi: 10.1093/conphys/cot002

Kabasakal, H. (2010). Post-release behavior and anthropogenic injuries of the bluntnose sixgill shark, Hexanchus griseus (Bonnaterre, 1788) (Chondrichthyes: Hexanchidae) in Turkish waters. Annales, Series Historia Naturalis 20, 39-46.

Kaimmer, S. M. (1994). Halibut injury and mortality associated with manual and automated removal from setline hooks. Fisheries Research 20, 165-179.

Kajiura, S. M., Sebastian, A. P. \& Tricas, T. C. (2000). Dermal bite wounds as indicators of reproductive seasonality and behaviour in the Atlantic stingray, Dasyatis sabina. Environmental Biology of Fishes 58, 23-31.

Kaiser, M. J., Bullimore, B., Newman, P., Lock, K. \& Gilbert, S. (1996). Catches in 'ghost fishing' set nets. Marine Ecology Progress Series 145, 11-16.

Kaiser, M. J. \& Spencer, B. E. (1995) Survival of by-catch from a beam trawl. Marine Ecology Progress Series 126, 31-38.

Kneebone, J., Chisholm, J., Bernal, D. \& Skomal, G. (2013). The physiological effects of capture stress, recovery, and post-release survivorship of juvenile sand tigers (Carcharias taurus) caught on rod and reel. Fisheries Research 147, 103-114.

Kohler, N. E. \& Turner, P. A. (2001). Shark tagging: a review of conventional methods and studies. In The behavior and sensory biology of elasmobranch fishes: an anthology in memory of Donald Richard Nelson. Springer, Netherlands, pp. 191-224.

Kotwicki, S. \& Weinberg, K. L. (2005). Estimating capture probability of a survey bottomtrawl for Bering Sea skates (Bathyraja spp.) and other fish. Alaska Fishery Research Bulletin 11, 135-145. 
Kynoch, R. J., Fryer, R. J. \& Neat, F. C. (2015). A simple technical measure to reduce bycatch and discard of skates and sharks in mixed-species bottom-trawl fisheries. ICES Journal of Marine Science, doi: 10.1093/icesjms/fsv037.

Laptikhovsky, V. V. (2004). Survival rates for rays discarded by the bottom trawl squid fishery off the Falkland Islands. Fishery Bulletin 102, 757-759.

Lomeli, M. J. \& Wakefield, W. W. (2013). A flexible sorting grid to reduce Pacific halibut (Hippoglossus stenolepis) bycatch in the US west coast groundfish bottom trawl fishery. Fisheries Research 143, 102-108.

Lyons, K., Jarvis, E. T., Jorgensen, S. J., Weng, K., O'Sullivan, J., Winkler, C. \& Lowe, C. G. (2013). The degree and result of gillnet fishery interactions with juvenile white sharks in southern California assessed by fishery-independent and-dependent methods. Fisheries Research $147,370-380$.

Mandelman, J. W. \& Farrington, M. A. (2007b). The estimated short-term discard mortality of a trawled elasmobranch, the spiny dogfish (Squalus acanthias). Fisheries Research 83, 238245.

Mandelman, J. W. \& Farrington, M. A. (2007a). The physiological status and mortality associated with otter-trawl capture, transport, and captivity of an exploited elasmobranch, Squalus acanthias. ICES Journal of Marine Science 64, 122-130.

Mandelman, J. W. \& Skomal, G. B. (2009). Differential sensitivity to capture stress assessed by blood acid-base status in five carcharhinid sharks. Journal of Comparative Physiology $B$ $179,267-277$.

Mandelman, J. W., Cicia, A. M., Ingram Jr, G. W., Driggers III, W. B., Coutre, K. M. \& Sulikowski, J. A. (2012). Short-term post-release mortality of skates (family Rajidae) discarded in a western North Atlantic commercial otter trawl fishery. Fisheries Research 139, 76-84.

Mandelman, J. W., Cooper, P. W., Werner, T. B. \& Lageux, K. M. (2008). Shark bycatch and depredation in the US Atlantic pelagic longline fishery. Reviews in Fish Biology and Fisheries $18,427-442$. 
Manire, C., Hueter, R., Hull, E. \& Spieler, R. (2001). Serological changes associated with gillnet capture and restraint in three species of sharks. Transactions of the American Fisheries Society $130,1038-1048$.

Marshall, H., Field, L., Afiadata, A., Sepulveda, C., Skomal, G. \& Bernal, D. (2012). Hematological indicators of stress in longline-captured sharks. Comparative Biochemistry and Physiology (Part A) 162, 121-129.

Marshall, H., Skomal, G., Ross, P. G. \& Bernal, D. (2015). At-vessel and post-release mortality of the dusky (Carcharhinus obscurus) and sandbar (C. plumbeus) sharks after longline capture. Fisheries Research 172, 373-384.

Mas, F., Forselledo, R. \& Domingo, A. (2015). Mobulid ray by-catch in longline fisheries in the south-western Atlantic Ocean. Marine and Freshwater Research 66, 767-777.

Megalofonou, P., Yannopoulos, C., Damalas, D., De Metrio, G., Deflorio, M., de la Serna, J. M. \& Macias, D. (2005). Incidental catch and estimated discards of pelagic sharks from the swordfish and tuna fisheries in the Mediterranean Sea. Fishery Bulletin 103 620-634.

Molina, J. M. \& Cooke, S. J. (2012). Trends in shark bycatch research: current status and research needs. Reviews in Fish Biology and Fisheries 22, 719-737.

Morgan, A. \& Burgess, G. H. (2007). At-vessel fishing mortality for six species of sharks caught in the Northwest Atlantic and Gulf of Mexico. Gulf and Caribbean Research 19, 123-129.

Morgan, A. \& Carlson, J. K. (2010). Capture time, size and hooking mortality of bottom longline-caught sharks. Fisheries Research 101, 32-37.

Moyes, C. D., Fragoso, N., Musyl, M. K. \& Brill, R. W. (2006). Predicting postrelease survival in large pelagic fish. Transactions of the American Fisheries Society 135, 1389-1397.

Musyl, M. K., Brill, R. W., Curran, D. S., Fragoso, N. M., McNaughton, L. M., Nielsen, A., Kikkawa, B. S. \& Moyes, C. D. (2011). Postrelease survival, vertical and horizontal movements, and thermal habitats of five species of pelagic sharks in the central Pacific Ocean. Fishery Bulletin 109, 341-368.

Musyl, M. K., Moyes, C. D., Brill, R. W. \& Fragoso, N. M. (2009). Comment: Factors influencing mortality estimates in post release survival studies. Marine Ecology Progress Series 396, 157-159. 
Piovano, S., Clò, S. \& Giacoma, C. (2010). Reducing longline bycatch: the larger the hook, the fewer the stingrays. Biological Conservation 143, 261-264.

Poisson, F., Filmalter, J. D., Vernet, A.-L. \& Dagorn, L. (2014a). Mortality rate of silky sharks (Carcharhinus falciformis) caught in the tropical tuna purse seine fishery in the Indian Ocean. Canadian Journal of Fisheries and Aquatic Sciences 71, 795-798.

Poisson, F., Gaertner, J.C., Taquet, M., Durbec, J. P. \& Bigelow, K. (2010). Effects of lunar cycle and fishing operations on longline-caught pelagic fish: fishing performance, capture time, and survival of fish. Fishery Bulletin 108, 268-281.

Poisson, F., Séret, B., Vernet, A.L., Goujon, M. \& Dagorn, L., (2014b). Collaborative research: Development of a manual on elasmobranch handling and release best practices in tropical tuna purse-seine fisheries. Marine Policy 44, 312-320.

Pollock, K. H. \& Pine, W. E. (2007). The design and analysis of field studies to estimate catchand-release mortality. Fisheries Management and Ecology 14, 123-130.

Pratt, H. L. (1979). Reproduction in the blue shark, Prionace glauca. Fishery Bulletin 77, 445470.

Raborn, S. W., Gallaway, B. J., Cole, J. G., Gazey, W. J. \& Andrews, K. I. (2012). Effects of Turtle Excluder Devices (TEDs) on the bycatch of three small coastal sharks in the Gulf of Mexico penaeid shrimp fishery. North American Journal of Fisheries Management 32, 333-345.

Rafferty, A. R., Brazer, E. O. \& Reina, R. D. (2012). Depredation by harbor seal and spiny dogfish in a Georges Bank gillnet fishery. Fisheries Management and Ecology 19, 264-272.

Reid, D. D. \& Krogh, M. (1992). Assessment of catches from protective shark meshing off NSW beaches between 1950 and 1990. Marine and Freshwater Research 43, 283-296.

Revill, A. S., Dulvy, N. K. \& Holst, R. (2005). The survival of discarded lesser-spotted dogfish (Scyliorhinus canicula) in the Western English Channel beam trawl fishery. Fisheries Research 71, 121-124.

Robbins, W. D., Peddemors, V. M., Broadhurst, M. K. \& Gray, C. A. (2013). Hooked on fishing? Recreational angling interactions with the Critically Endangered grey nurse shark Carcharias taurus in eastern Australia. Endangered Species Research 21, 161-170. 
Rodríguez-Cabello, C., Fernández, A., Olaso, I. \& Sánchez, F. (2005). Survival of small-spotted catshark (Scyliorhinus canicula) discarded by trawlers in the Cantabrian Sea. Journal of the Marine Biological Association of the United Kingdom 85, 1145-1150.

Rodríguez-Cabello, C. \& Sánchez, F. (2014). Is Centrophorus squamosus a highly migratory deep-water shark? Deep Sea Research Part I: Oceanographic Research Papers 92, 1-10.

Rulifson, R. A. (2007). Spiny dogfish mortality induced by gill-net and trawl capture and tag and release. North American Journal of Fisheries Management 27, 279-285.

Saygu, I. \& Deval, M. C. (2014). The post-release survival of two skate species discarded by bottom trawl fisheries in Antalya Bay, eastern Mediterranean. Turkish Journal of Fisheries and Aquatic Sciences 14, 1-7.

Schwartz, F. J. (1984). A blacknose shark from North Carolina deformed by encircling monofilament line. Florida Scientist 47, 62-64.

Scott-Denton, E., Cryer, P. F., Gocke, J. P., Harrelson, M. R., Kinsella, D. L., Pulver, J. R., Smith, R. C. \& Williams, J. A. (2011). Descriptions of the U.S. Gulf of Mexico reef fish bottom longline and vertical line fisheries based on observer data. Marine Fisheries Review 73, 126.

Seitz, J. C. \& Poulakis, G. R. (2006). Anthropogenic effects on the smalltooth sawfish (Pristis pectinata) in the United States. Marine Pollution Bulletin 52, 1533-1540.

Sepulveda, C. A., Heberer, C., Aalbers, S. A., Spear, N., Kinney, M., Bernal, D. \& Kohin, S. (2015). Post-release survivorship studies on common thresher sharks (Alopias vulpinus) captured in the southern California recreational fishery. Fisheries Research 161, 102-108.

Serafy, J. E., Orbesen, E. S., Snodgrass, D. J., Beerkircher, L. R. \& Walter, J. F. (2012). Hooking survival of fishes captured by the United States Atlantic pelagic longline fishery: impact of the 2004 circle hook rule. Bulletin of Marine Science 88, 605-621.

Silva, J. F., Ellis, J. R. \& Catchpole, T. L. (2012). Species composition of skates (Rajidae) in commercial fisheries around the British Isles, and their discarding patterns. Journal of Fish Biology 80, 1678-1703.

Sims, D. W., Andrews, P. L. \& Young, J. Z. (2000). Fish behaviour: stomach rinsing in rays. Nature 404, 566. 
Skomal, G. B. (2007). Evaluating the physiological and physical consequences of capture on post-release survivorship in large pelagic fishes. Fisheries Management and Ecology 14, 81-89.

Skomal, G. B. \& Chase, B. C. (2002). The physiological effects of angling on post-release survivorship in tunas, sharks, and marlin. American Fisheries Society Symposium 30, 135138.

Skomal, G., Lobel, P. S. \& Marshall, G. (2007). The use of animal-borne imaging to assess postrelease behavior as it relates to capture stress in grey reef sharks, Carcharhinus amblyrhynchos. Marine Technology Society Journal 41(4), 44-48.

Skomal, G. B. \& Mandelman, J. W. (2012). The physiological response to anthropogenic stressors in marine elasmobranch fishes: a review with a focus on the secondary response. Comparative Biochemistry and Physiology (Part A) 162, 146-155.

Stobutzki, I. C., Miller, M. J., Heales, D. S. \& Brewer, D. T. (2002). Sustainability of elasmobranchs caught as bycatch in a tropical prawn (shrimp) trawl fishery. Fishery Bulletin $100,800-821$.

Storai, T., Zinzula, L., Repetto, S., Zuffa, M., Morgan, A. \& Mandelman, J. (2011). Bycatch of large elasmobranchs in the traditional tuna traps (tonnare) of Sardinia from 1990 to 2009. Fisheries Research 109, 74-79.

Thorpe, T. \& Frierson, D. (2009). Bycatch mitigation assessment for sharks caught in coastal anchored gillnets. Fisheries Research 98, 102-112.

Trinnie, F. I., Walker, T. I., Jones, P. L. \& Laurenson, L. J. (2012). Biennial reproductive cycle in an extensive matrotrophic viviparous batoid: the sandyback stingaree Urolophus bucculentus from south-eastern Australia. Journal of Fish Biology 80, 1267-1291.

Uhlmann, S. S. \& Broadhurst, M. K. (2015). Mitigating unaccounted fishing mortality from gillnets and traps. Fish and Fisheries 16, 183-229.

Valeiras, J., Lopez, A. \& Garcia, M. (2001). Geographical, seasonal occurrence and incidental fishing captures of basking shark Cetorhinus maximus (Chondrichthyes: Cetorhinidae). Journal of the Marine Biological Association of the United Kingdom 81, 183-184. 
Walker, T. I., Hudson, R. J. \& Gason, A. S. (2005). Catch evaluation of target, by-product and by-catch species taken by gillnets and longlines in the shark fishery of south-eastern Australia. Journal of Northwest Atlantic Fishery Science 35, 505-530.

Walsh, S. J. (1992). Size-dependent selection at the footgear of a groundfish survey trawl. North American Journal of Fisheries Management 12, 625-633.

Walsh, W. A., Bigelow, K. A. \& Sender, K. L. (2009). Decreases in shark catches and mortality in the Hawaii-based longline fishery as documented by fishery observers. Marine and Coastal Fisheries: Dynamics, Management, and Ecosystem Science 1, 270-282.

Waples, D. M., Thorne, L. H., Hodge, L. E., Burke, E. K., Urian, K. W. \& Read, A. J. (2013). A field test of acoustic deterrent devices used to reduce interactions between bottlenose dolphins and a coastal gillnet fishery. Biological Conservation 157, 163-171.

Ward, P., Lawrence, E., Darbyshire, R. \& Hindmarsh, S. (2008). Large-scale experiment shows that nylon leaders reduce shark bycatch and benefit pelagic longline fishers. Fisheries Research 90, 100-108.

Wegner, N. C. \& Cartamil, D. P. (2012). Effects of prolonged entanglement in discarded fishing gear with substantive biofouling on the health and behavior of an adult shortfin mako shark, Isurus oxyrinchus. Marine Pollution Bulletin 64, 391-394.

Wells, R. G. M. \& Davie, P. S. (1985). Oxygen binding by the blood and haematological effects of capture stress in two big game-fish: mako shark and striped marlin. Comparative Biochemistry and Physiology 81A, 643-646.

Willems, T., Depestele, J., De Backer, A. \& Hostens, K. (2016). Ray bycatch in a tropical shrimp fishery: Do Bycatch Reduction Devices and Turtle Excluder Devices effectively exclude rays? Fisheries Research 175, 35-42.

Wood, C. M., Turner, J. D. \& Graham, M. S. (1983). Why do fish die after severe exercise? Journal of Fish Biology 22, 189-201.

Yokota, K., Kiyota, M. \& Minami, H. (2006). Shark catch in a pelagic longline fishery: comparison of circle and tuna hooks. Fisheries Research 81, 337-341.

Zeeberg, J., Corten, A. \& de Graaf, A. (2006). Bycatch and release of pelagic megafauna in industrial trawler fisheries off Northwest Africa. Fisheries Research 78, 186-195. 


\section{Electronic References}

Bendall, V. A., Hetherington, S. J., Ellis, J. R., Smith, S. F., Ives, M. J., Gregson, J. \& Riley, A. A. (2012). Spurdog, porbeagle and common skate bycatch and discard reduction. Fisheries Science Partnership 2011-2012, Final Report; 88 pp. Available at http://webarchive.nationalarchives.gov.uk/20150203151336/http:/www.cefas.defra.gov. $\underline{\text { uk/publications-and-data/scientific-series/fisheries-science-partnership-reports.aspx }}$

Benoît, H. P., Swain, D. P., Niles, M., LeBlanc, S. \& Davidson, L. A. (2010b). Incidental catch amounts and potential post-release survival of winter skate (Leucoraja ocellata) captured in the scallop dredge fishery in the southern Gulf of St. Lawrence (2006-2008). Canadian Science Advisory Secretariat Research Document 2010/043; 20 pp. Available at http://www.dfo-mpo.gc.ca/csas-sccs/publications/resdocsdocrech/2010/2010 043 e.pdf

Campana, S. E., Brading, J. \& Joyce, W. (2011). Estimation of pelagic shark bycatch and associated mortality in Canadian Atlantic fisheries. DFO Canadian Scientific Advisory Secretariat Research Document 2011/067: vi + 19 pp. Available at http://www.dfompo.gc.ca/csas-sccs/Publications/ResDocs-DocRech/2011/2011_067-eng.html

Coelho, R., Lino, P. G. \& Santos, M. N. (2011). At-haulback mortality of elasmobranchs caught on the Portuguese longline swordfish fishery in the Indian Ocean. IOTC-2011-WPEB0731; 9 pp. Available at http://www.iotc.org/documents/haulback-mortalityelasmobranchs-caught-portuguese-longline-swordfish-fishery-indian-ocean

Ellis, J. R., Burt, G. J., Cox, L. P. N., Kulka, D. W \& Payne, A. I. L. (2008b). The status and management of thornback ray Raja clavata in the south-western North Sea. ICES CM 2008/K:13, 45 pp. Available at http://www.ices.dk/sites/pub/CM\%20Doccuments/CM2008/K/K1308.pdf

Ellis, J. R., McCully, S. R., Silva, J. F., Catchpole, T. L., Goldsmith, D., Bendall, V. \& Burt, G. (2012). Assessing discard mortality of commercially caught skates (Rajidae) - validation of experimental results. DEFRA Report MB5202, $142 \mathrm{pp}$. Available at http://randd.defra.gov.uk/Default.aspx?Menu=Menu\&Module=More\&Location=None\&C ompleted $=0 \&$ Project ID $=17021$ 
European Union (2013). Regulation (EU) No 1380/2013 of the European Parliament and of the CounclL of 11 December 2013 on the Common Fisheries Policy, amending Council Regulations (EC) No 1954/2003 and (EC) No 1224/2009 and repealing Council Regulations (EC) No 2371/2002 and (EC) No 639/2004 and Council Decision 2004/585/EC. Official Journal of the European Union, L354: 22-61. Available at http://eur-lex.europa.eu/legalcontent/EN/TXT/?uri=celex:32013R1380

European Union (2016). Council Regulation (EU) No 2016/72 of 22 January 2016 fixing for 2016 the fishing opportunities for certain fish stocks and groups of fish stocks, applicable in Union waters and, for Union fishing vessels, in certain non-Union waters, and amending Regulation (EU) 2015/104. Official Journal of the European Union, L22, 1-165. Available at http://ec.europa.eu/fisheries/cfp/fishing rules/tacs/index en.htm

Hutchinson, M., Itano, D., Muir, J., Leroy, B. \& Holland, K. (2013). Fishery interactions and post-release survival rates of silky sharks caught in purse seine fishing gear. WCPFC-SC92013/EB-WP-12: 26 pp. Available at https://www.wcpfc.int/node/4736

ICES (2015). Report of the Working Group on Elasmobranch Fishes (WGEF), 17-23 June 2015, Lisbon, Portugal. ICES CM 2015/ACOM:19; 711 pp. Available at http://ices.dk/sites/pub/Publication\%20Reports/Expert\%20Group\%20Report/acom/2015 WGEF/wgef 2015.pdf

Lawson, D., DeAlteris, J. \& Parkins, C. (2007). An evaluation of the catch efficiency of a NMFS certified, standard turtle excluder device (TED) required in the Mid-Atlantic summer flounder fishery. Contract EA133F-05-SE-6561, Woods Hole, Massachusetts. Available at http://www.nefsc.noaa.gov/publications/reports/EA133F-05-SE-6561.pdf

Lyle, J. M., Bell, J. D., Chuwen, B. M., Barrett, N., Tracey, S. R. \& Buxton, C. D. (2014). Assessing the impacts of gillnetting in Tasmania: Implications for by-catch and biodiversity. Institute for Marine and Antarctic Studies, University of Tasmania. Fisheries Research and Development Corporation (FRDC) Project No. 2010/016, xiv + 176 pp. Available at http://dpipwe.tas.gov.au/Documents/Gillnetting_Impacts_Tas Bycatch Biodiversity FR DC2010.pdf

McLoughlin, K. \& Eliason, G. (2008). Review of information on cryptic mortality and the survival of sharks and rays released by recreational fishers. Commonwealth of Australia: 
Bureau of Rural Sciences Report, iv +22 pp. Available at http://sedarweb.org/docs/wsupp/S21 RD22.pdf

Rudders, D. B., Knotek, R. J., Sulikowski, J. A., Mandleman, J. A. \& Benoît, H. P. (2015). Evaluating the condition and discard mortality of skates following capture and handling in the sea scallop dredge fishery. VIMS Marine Resource Report No. 2015-6. Available at http://s3.amazonaws.com/nefmc.org/2.2-FR12-0030 VIMS-.pdf 
Fig. 1. Gillnet-caught spurdog S. acanthias in which the internal organs have been partially eaten by scavenging isopods (inset).
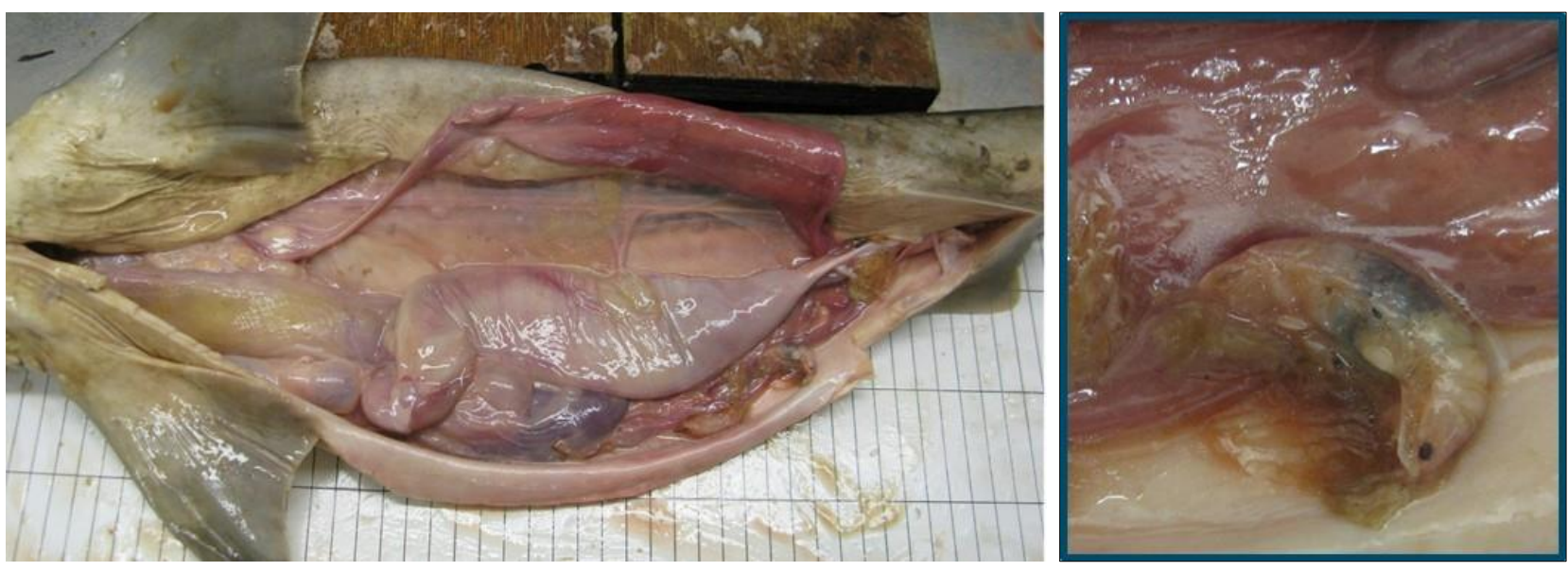
Fig. 2. Trawl-caught starry smooth-hound M. asterias showing evidence of prior capture by gillnet.

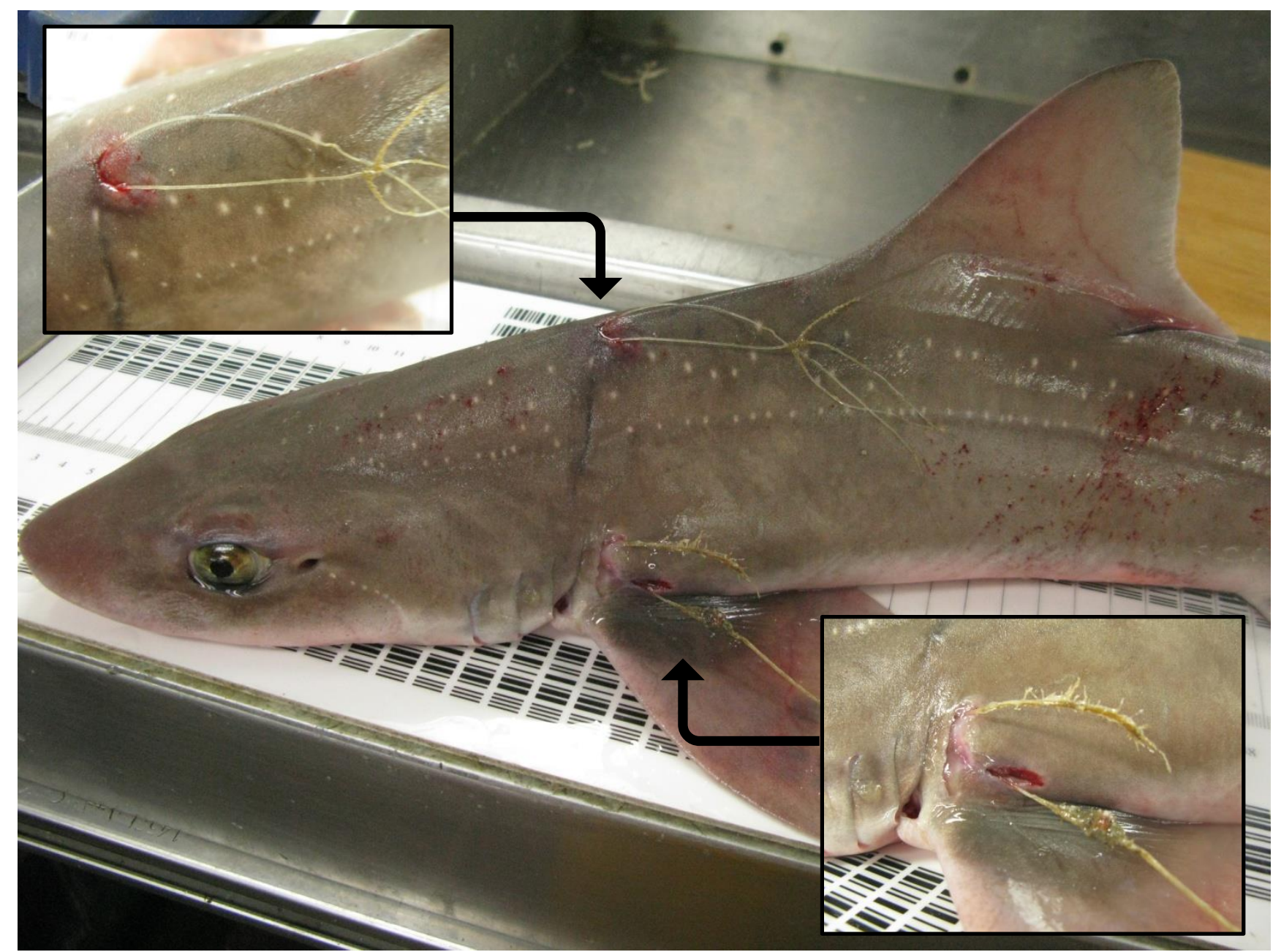


Fig. 3. Trawl or gillnet-caught spurdog S. acanthias showing evidence of prior capture by longline showing (a-b) various stages of healing of jaws, (c) hook in body cavity (note that the poor state of the liver may be an artefact of freezing and thawing), and (d) hook that has penetrated into the pericardial cavity, close to the heart.
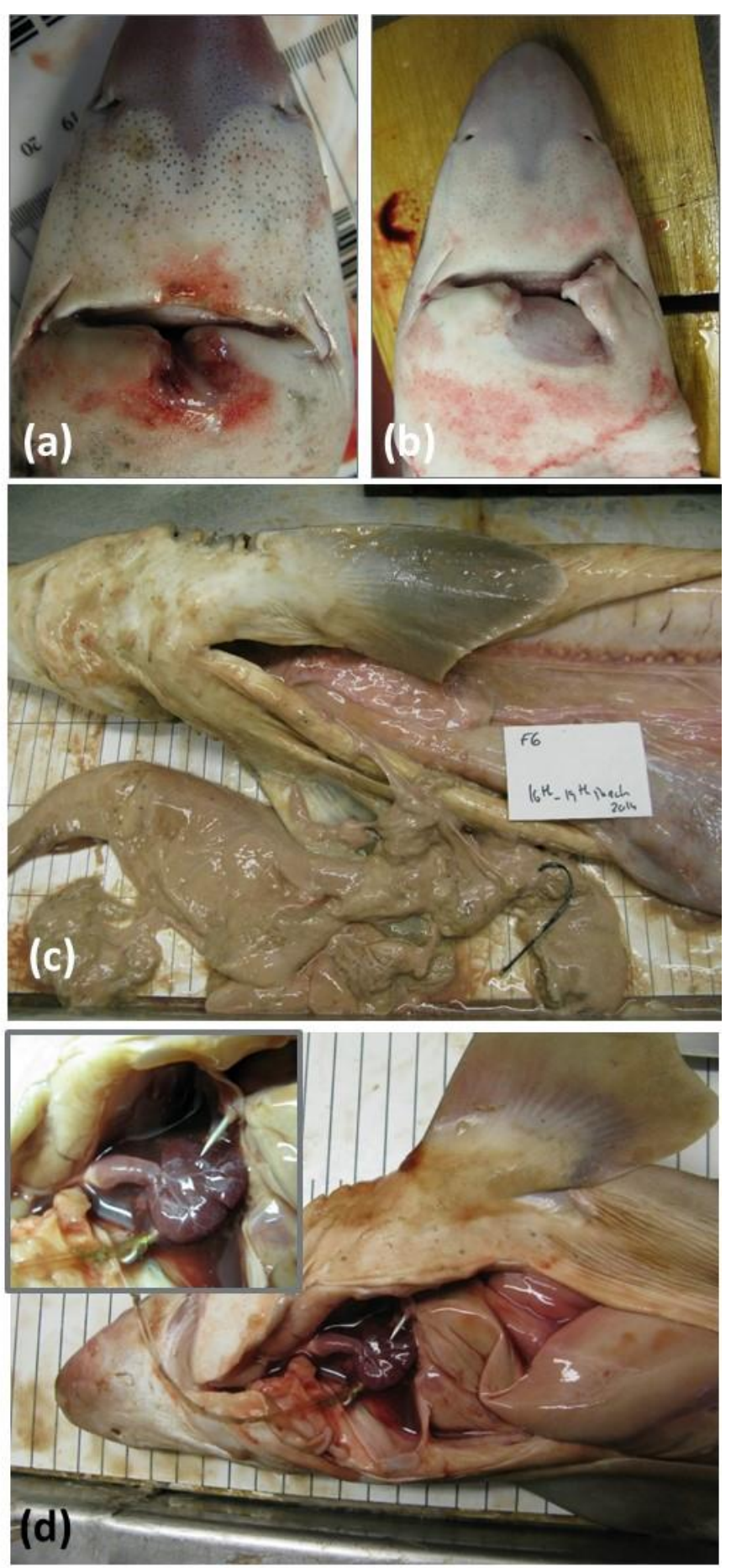
Table I: Example descriptions for condition of fish in discard studies (Adapted from Benoît et al. 2010b)

\begin{tabular}{|c|c|c|c|}
\hline Condition & Number & Category & Description \\
\hline \multirow[t]{4}{*}{ Vitality } & 1 & Good & $\begin{array}{l}\text { Strong body movements; spiracles (if present) moving; } \\
\text { no or only minor injuries }\end{array}$ \\
\hline & 2 & Fair & $\begin{array}{l}\text { Weak body movements; some spiracular movement; } \\
\text { minor injuries }\end{array}$ \\
\hline & 3 & Poor & $\begin{array}{l}\text { No obvious body movements; limited spiracular } \\
\text { movements; minor or major injuries }\end{array}$ \\
\hline & 4 & Moribund & No movements of body or spiracle \\
\hline \multirow[t]{3}{*}{ Injury } & 1 & None & No bleeding or injuries apparent \\
\hline & 2 & Minor & $\begin{array}{l}\text { Minor bleeding; some damage to mouth parts (e.g. in } \\
\text { longline fisheries) }\end{array}$ \\
\hline & 3 & Major & Major bleeding; extensive damage to mouth parts \\
\hline
\end{tabular}


Table II: Summary of studies examining AVM (\%) and other elements of discard survival of elasmobranch fish by gear. Data for AVM in parentheses relate to small sample sizes.

\begin{tabular}{|c|c|c|c|c|c|c|c|c|}
\hline Fishery & Study area & Approach & Details & Family & Species & AVM & Key findings & Source \\
\hline \multicolumn{9}{|l|}{ TRAWL } \\
\hline \multirow{18}{*}{$\begin{array}{l}\text { Commercial prawn } \\
\text { trawl (otter trawl, } 38 \\
\text { mm stretched mesh } \\
\text { cod-end, } 2-3 \text { knot } \\
\text { trawl speed; fishing } \\
\text { depths of } 20-45 \mathrm{~m} \text { ) }\end{array}$} & \multirow{18}{*}{$\begin{array}{l}\text { Natal } \\
\text { (Indian Ocean) }\end{array}$} & \multirow[t]{18}{*}{ AVM } & & Squatinidae & Squatina africana $(\mathrm{n}=10)$ & $60 \%$ & & \multirow{18}{*}{$\begin{array}{l}\text { Fennessy } \\
\text { (1994) }\end{array}$} \\
\hline & & & & $\begin{array}{l}\text { Stegostomatida } \\
\text { e }\end{array}$ & $\begin{array}{l}\text { Stegostoma fasciatum }(\mathrm{n}= \\
\text { 1) }\end{array}$ & $(0 \%)$ & & \\
\hline & & & & Scyliorhinidae & $\begin{array}{l}\text { Halaelurus lineatus }(\mathrm{n}= \\
\text { 47) }\end{array}$ & $19.2 \%$ & & \\
\hline & & & & Triakidae & Mustelus mosis $(\mathrm{n}=14)$ & $28.6 \%$ & & \\
\hline & & & & Carcharhinidae & $\begin{array}{l}\text { Carcharhinus amboinensis } \\
(n=1)\end{array}$ & - & & \\
\hline & & & & & $\begin{array}{l}\text { Carcharhinus brevipinna ( } \mathrm{n} \\
=25 \text { ) }\end{array}$ & $56 \%$ & & \\
\hline & & & & & $\begin{array}{l}\text { Carcharhinus obscurus ( } \mathrm{n}= \\
\text { 8) }\end{array}$ & $(12.5 \%)$ & & \\
\hline & & & & & $\begin{array}{l}\text { Carcharhinus plumbeus ( } \mathrm{n} \\
=6 \text { ) }\end{array}$ & $(33.3 \%)$ & & \\
\hline & & & & & $\begin{array}{l}\text { Rhizoprionodon acutus }(\mathrm{n}= \\
24 \text { ) }\end{array}$ & $29.2 \%$ & & \\
\hline & & & & Sphyrnidae & Sphyrna lewini $(\mathrm{n}=169)$ & $97.6 \%$ & & \\
\hline & & & & & $\begin{array}{l}\text { Rhinobatus annulatus }(\mathrm{n}= \\
\text { 9) }\end{array}$ & $(11.1 \%)$ & \multirow{8}{*}{$\begin{array}{l}\mathrm{AVM}=32.5 \% \text { for } \\
\text { rhinobatoids (all } \\
\text { species } \\
\text { combined) }\end{array}$} & \\
\hline & & & & & $\begin{array}{l}\text { Rhinobatus leucospilus ( } \mathrm{n}= \\
\text { 19) }\end{array}$ & $52.6 \%$ & & \\
\hline & & & & Torpedinidae & Torpedo sinuspersici $(\mathrm{n}=5)$ & $(40 \%)$ & & \\
\hline & & & & Rajidae & Raja miraletus $(\mathrm{n}=2)$ & $(0 \%)$ & & \\
\hline & & & & Dasyatidae & $\begin{array}{l}\text { Dasyatis chrysonata }(\mathrm{n}= \\
\text { 34) }\end{array}$ & $17.7 \%$ & & \\
\hline & & & & & Dasyatis thetidis $(\mathrm{n}=10)$ & $70 \%$ & & \\
\hline & & & & & $\begin{array}{l}\text { Himantura gerrardi }(n= \\
\text { 47) }\end{array}$ & $42.6 \%$ & & \\
\hline & & & & & Himantura uarnak $(\mathrm{n}=16)$ & $25 \%$ & & \\
\hline
\end{tabular}




\begin{tabular}{|c|c|c|c|c|c|c|c|c|}
\hline Fishery & Study area & Approach & Details & Family & Species & AVM & Key findings & Source \\
\hline & & & & Gymnuridae & $\begin{array}{l}\text { Gymnura natalensis }(\mathrm{n}= \\
84)\end{array}$ & $46.4 \%$ & $\begin{array}{l}\text { AVM was lower in } \\
\text { tows of }<2 \mathrm{~h} \\
\text { duration; } \mathrm{AVM} \\
\text { higher in larger } \\
\text { catches }\end{array}$ & \\
\hline & & & & Myliobatidae & $\begin{array}{l}\text { Aetobatus narinari }(\mathrm{n}=3) \\
\text { Myliobatis aquila }(\mathrm{n}=4)\end{array}$ & $\begin{array}{r}(0.0 \%) \\
(50.0 \%)\end{array}$ & $\begin{array}{l}\text { AVM }=27.3 \% \text { for } \\
\text { myliobatids (all }\end{array}$ & \\
\hline & & & & & $\begin{array}{l}\text { Pteromylaeus bovinus }(\mathrm{n}= \\
\text { 4) }\end{array}$ & $(25.0 \%)$ & $\begin{array}{l}\text { species } \\
\text { combined) }\end{array}$ & \\
\hline \multirow{7}{*}{$\begin{array}{l}\text { Commercial prawn } \\
\text { trawl (research } \\
\text { surveys and observer } \\
\text { data) }\end{array}$} & \multirow{7}{*}{$\begin{array}{l}\text { Northern } \\
\text { Australia }\end{array}$} & \multirow{7}{*}{ AVM } & \multirow{7}{*}{$\begin{array}{l}\text { Elasmobranchs } \\
\text { categorised as live } \\
\text { or dead }\end{array}$} & \multirow{3}{*}{ Carcharhinidae } & $\begin{array}{l}\text { Carcharhinus sorrah }(\mathrm{n}= \\
23 \text { ) }\end{array}$ & $65 \%$ & & \\
\hline & & & & & $\begin{array}{l}\text { Carcharhinus tilstoni }(\mathrm{n}= \\
73)\end{array}$ & $82 \%$ & & \\
\hline & & & & & $\begin{array}{l}\text { Rhizoprionodon acutus }(\mathrm{n}= \\
116 \text { ) }\end{array}$ & $82 \%$ & & \\
\hline & & & & Hemigaleidae & $\begin{array}{l}\text { Hemigaleus microstoma }(\mathrm{n} \\
=68)\end{array}$ & $62 \%$ & & \\
\hline & & & & Rhinidae & $\begin{array}{l}\text { Rhynchobatus djiddensis ( } \mathrm{n} \\
=59 \text { ) }\end{array}$ & $10 \%$ & & \\
\hline & & & & Dasyatidae & Himantura toshi $(\mathrm{n}=58)$ & $53 \%$ & & \\
\hline & & & & Gymnuridae & Gymnura australis $(n=34)$ & $41 \%$ & & \\
\hline $\begin{array}{l}\text { Bottom trawl squid } \\
\text { fishery (cod-end } \\
\text { mesh size of } 110 \\
\mathrm{~mm} ; 3.8-4.2 \mathrm{~km} \\
\text { trawl speed; } 80-190 \\
\mathrm{~m} \text { fishing depth) }\end{array}$ & $\begin{array}{l}\text { SW Atlantic } \\
\text { (Falkland } \\
\text { Islands) }\end{array}$ & $\begin{array}{l}\text { Short- } \\
\text { term } \\
\text { survival }\end{array}$ & $\begin{array}{l}\text { Random sample of } \\
\text { skates placed in on- } \\
\text { board tanks to } \\
\text { assess health over } \\
\text { periods of up to } 2.3 \\
\text { h }\end{array}$ & $\begin{array}{l}\text { Arhynchobatida } \\
\text { e }\end{array}$ & $\begin{array}{l}\text { Bathyraja albomaculata }(\mathrm{n} \\
=14) \\
\text { Bathyraja brachyurops }(\mathrm{n}= \\
\text { 11) } \\
\text { Bathyraja griseocauda }(\mathrm{n}= \\
\text { 3) } \\
\text { Bathyraja macloviana }(\mathrm{n}= \\
\text { 2) } \\
\text { Bathyraja magellanica }(\mathrm{n}= \\
\text { 5) } \\
\text { Bathyraja sp. }(\mathrm{n}=16) \\
\text { Psammobatis } \mathrm{sp} .(\mathrm{n}=15)\end{array}$ & - & $\begin{array}{l}\text { For species } \\
\text { combined ( } n= \\
66), \text { mortality was } \\
31.8 \% \text { and a } \\
\text { further } 9.1 \% \text { were } \\
\text { dead or moribund } \\
\text { after the recovery } \\
\text { time. Overall } \\
\text { mortality was } \\
40.9 \% \text {. Females } \\
\text { showed a greater } \\
\text { survival }(66.7 \%) \\
\text { than males } \\
(56.4 \%)\end{array}$ & $\begin{array}{l}\text { Laptikhovsky } \\
\text { (2004) }\end{array}$ \\
\hline
\end{tabular}




\begin{tabular}{|c|c|c|c|c|c|c|c|c|}
\hline Fishery & Study area & Approach & Details & Family & Species & AVM & Key findings & Source \\
\hline $\begin{array}{l}\text { Otter trawl (baca) } \\
\text { with cod-end liner } \\
\text { deployed from } \\
\text { research vessel ( } 0.5 \\
h \text { tow duration) }\end{array}$ & $\begin{array}{l}\text { NE Atlantic } \\
\text { (Cantabrian } \\
\text { Sea) }\end{array}$ & $\begin{array}{l}\text { Short- } \\
\text { term } \\
\text { survival }\end{array}$ & $\begin{array}{l}\text { Specimens left on } \\
\text { deck for known } \\
\text { periods to simulate } \\
\text { catch processing } \\
\text { time, then } \\
\text { maintained in a tank } \\
\text { for } 1 \mathrm{~h} \text { before } \\
\text { categorisation as } \\
\text { alive or dead }\end{array}$ & Scyliorhinidae & Scyliorhinus canicula & - & $\begin{array}{l}\text { Mean survival } \\
\text { rate was } 90 \% \text {, } \\
\text { ranging from } 60- \\
100 \% \text {. Survival } \\
\text { decreased with } \\
\text { increased sorting } \\
\text { time }\end{array}$ & $\begin{array}{l}\text { Rodríguez- } \\
\text { Cabello et al. } \\
\text { (2005) }\end{array}$ \\
\hline $\begin{array}{l}\text { Otter trawl (baca) } \\
\text { deployed from } \\
\text { commercial vessels } \\
\text { (3-6 h tow duration) }\end{array}$ & $\begin{array}{l}\text { NE Atlantic } \\
\text { (Cantabrian } \\
\text { Sea) }\end{array}$ & & As above & Scyliorhinidae & Scyliorhinus canicula & - & $\begin{array}{l}\text { Mean survival } \\
\text { rate was } 78 \%, \\
\text { ranging from 47- } \\
98 \% \text {. Suggestion } \\
\text { of reduced } \\
\text { survival with } \\
\text { increased depth } \\
\text { and increased } \\
\text { sorting time, but } \\
\text { results not } \\
\text { significant }\end{array}$ & $\begin{array}{l}\text { Rodríguez- } \\
\text { Cabello et al. } \\
\text { (2005) }\end{array}$ \\
\hline $\begin{array}{l}\text { 'Danish' otter trawl } \\
\text { deployed from } \\
\text { commercial vessel } \\
\text { ( } 0.75 \mathrm{~h} \text { haul } \\
\text { duration) }\end{array}$ & NW Atlantic & $\begin{array}{l}\text { Short- } \\
\text { term } \\
\text { survival } \\
\text { and blood } \\
\text { sampling }\end{array}$ & $\begin{array}{l}\text { Spurdog caught, } \\
\text { transported ashore } \\
\text { and held in captivity } \\
(\mathrm{n}=34)\end{array}$ & Squalidae & Squalus acanthias & - & $\begin{array}{l}\text { AVM not } \\
\text { reported, but no } \\
\text { immediate post- } \\
\text { capture mortality } \\
\text { observed in sub- } \\
\text { sample examined. } \\
5.9 \% \text { mortality } \\
\text { following } \\
\text { transport and } \\
\text { captive period of } \\
30 \text { days }\end{array}$ & $\begin{array}{l}\text { Mandelman } \\
\text { and Farrington } \\
\text { (2007a) }\end{array}$ \\
\hline
\end{tabular}




\begin{tabular}{|c|c|c|c|c|c|c|c|c|}
\hline Fishery & Study area & Approach & Details & Family & Species & AVM & Key findings & Source \\
\hline $\begin{array}{l}\text { 'Danish' otter trawl } \\
\text { deployed from } \\
\text { commercial vessel } \\
\text { (cod-end of } 152 \mathrm{~mm} \\
\text { mesh size; } 0.75-1.0 \\
\text { h haul duration; } 60- \\
72 \text { water depth) }\end{array}$ & NW Atlantic & $\begin{array}{l}\text { Short- } \\
\text { term } \\
\text { survival } \\
\text { and blood } \\
\text { sampling }\end{array}$ & $\begin{array}{l}\text { Samples of trawl- } \\
\text { caught spurdog } \\
\text { used for examining } \\
\text { short-term }(72 \mathrm{~h}) \\
\text { survival in sea pens } \\
\text { or used in sampling } \\
\text { blood parameters. A } \\
\text { control group were } \\
\text { sampled with hook- } \\
\text { and-line (46-56 m } \\
\text { depth) }\end{array}$ & Squalidae & Squalus acanthias & - & $\begin{array}{l}\text { AVM not } \\
\text { reported, but no } \\
\text { immediate post- } \\
\text { capture mortality } \\
\text { observed in sub- } \\
\text { samples } \\
\text { examined. Trawl- } \\
\text { caught fish } \\
\text { exhibited } 29 \% \\
\text { mortality over } 72 \\
\text { hours. No at- } \\
\text { vessel mortality } \\
\text { for fish caught by } \\
\text { hook-and-line, } \\
\text { with this control } \\
\text { group showing } \\
24 \% \text { mortality } \\
\text { over } 72 \text { hours. } \\
\text { Catch weight in } \\
\text { the trawl found to } \\
\text { be an important } \\
\text { factor affecting } \\
\text { survival, with } \\
\text { catches }>200 \mathrm{~kg} \\
\text { leading to higher } \\
72 \mathrm{~h} \text { mortality } \\
\text { estimates }\end{array}$ & $\begin{array}{l}\text { Mandelman } \\
\text { and Farrington } \\
\text { (2007b) }\end{array}$ \\
\hline
\end{tabular}




\begin{tabular}{|c|c|c|c|c|c|c|c|c|}
\hline Fishery & Study area & Approach & Details & Family & Species & AVM & Key findings & Source \\
\hline $\begin{array}{l}\text { Trawl (101 mm } \\
\text { stretch mesh; 0.5- } \\
1.5 \mathrm{~h} \text { haul duration) }\end{array}$ & NW Atlantic & $\begin{array}{l}\text { AVM and } \\
\text { short- } \\
\text { term } \\
\text { survival }\end{array}$ & $\begin{array}{l}\text { Immediate post- } \\
\text { capture mortality } \\
\text { recorded, live fish } \\
\text { maintained in sea } \\
\text { cages for } 48 \mathrm{~h}\end{array}$ & Squalidae & 更 & $0 \%$ & $\begin{array}{l}\text { All spurdog }(\mathrm{n}= \\
635) \text { that were } \\
\text { captured were } \\
\text { alive; all } \\
\text { specimens } \\
\text { maintained in sea } \\
\text { cages ( } \mathrm{n}=480) \\
\text { survived for } 48 \\
\text { hours. Some trawl } \\
\text { caught specimens } \\
(26 \%) \text { had } \\
\text { evidence of prior } \\
\text { gillnet damage. } \\
\text { Punctures and } \\
\text { gashes were more } \\
\text { frequent in trawl- } \\
\text { caught fish than } \\
\text { gillnet-caught fish. }\end{array}$ & Rulifson (2007) \\
\hline $\begin{array}{l}\text { Demersal trawls } \\
\text { deployed from } \\
\text { commercial inshore } \\
\text { vessels. The tow } \\
\text { durations (ca. } 0.5- \\
1.5 \mathrm{~h} \text { ), were as } \\
\text { normal practise for } \\
\text { this fishery }\end{array}$ & $\begin{array}{l}\text { NE Atlantic } \\
\text { (southern } \\
\text { North Sea) }\end{array}$ & $\begin{array}{l}\text { AVM and } \\
\text { tagging }\end{array}$ & $\begin{array}{l}\text { Health state } \\
\text { recorded on a three } \\
\text { point (lively, } \\
\text { sluggish, dead) and } \\
\text { fish tagged and } \\
\text { released }\end{array}$ & Rajidae & Raja clavata $(\mathrm{n}=3822)$ & $0.6 \%$ & $\begin{array}{l}\text { Overall, } 86.9 \% \\
\text { were categorised } \\
\text { as lively, } 12.5 \% \text { as } \\
\text { sluggish and } 0.6 \% \\
\text { as dead. These } \\
\text { data were } \\
\text { aggregated across } \\
\text { three vessels. } \\
\text { AVM highest for } \\
\text { fish }<50 \mathrm{~cm} \text { long } \\
(1.2 \%) \text {. These data } \\
\text { were collected by } \\
\text { observers, and so } \\
\text { fish were } \\
\text { processed } \\
\text { immediately after } \\
\text { capture. Mortality } \\
\text { would likely } \\
\text { increase if fish } \\
\text { remained on deck } \\
\text { whilst catch } \\
\text { processed. }\end{array}$ & $\begin{array}{l}\text { Ellis et al. } \\
\text { (2008a) }\end{array}$ \\
\hline
\end{tabular}




\begin{tabular}{|c|c|c|c|c|c|c|c|c|}
\hline Fishery & Study area & Approach & Details & Family & Species & AVM & Key findings & Source \\
\hline $\begin{array}{l}\text { Demersal trawl } \\
\text { (twin-rig otter trawl) }\end{array}$ & $\begin{array}{l}\text { NE Atlantic } \\
\text { (Bristol } \\
\text { Channel) }\end{array}$ & $\begin{array}{l}\text { Vitality } \\
\text { and short- } \\
\text { term } \\
\text { survival }\end{array}$ & $\begin{array}{l}\text { Survival of skates } \\
\text { examined in tows of } \\
\text { normal commercial } \\
\text { duration }(2.7-4.3 \mathrm{~h}) \\
\text { and shorter tows } \\
(0.75-2.0 \mathrm{~h}) . \text { Health } \\
\text { state of skates } \\
\text { scored }(1-3) \text { and } \\
\text { maintained in } \\
\text { survival tanks on } \\
\text { board. Health } \\
\text { scored for other } \\
\text { skates that were } \\
\text { tagged and } \\
\text { released. Cod-end } \\
\text { weight estimated. }\end{array}$ & Rajidae & $\begin{array}{l}\text { Various skates, including: } \\
\text { Leucoraja naevus } \\
\text { Raja brachyura } \\
\text { Raja clavata } \\
\text { Raja microocellata } \\
\text { Raja montagui }\end{array}$ & - & $\begin{array}{l}\text { No information on } \\
\text { AVM. Of the } \\
\text { skates that were } \\
\text { held in tanks for } \\
\text { up to } 64 \mathrm{~h} \text {, the } \\
\text { mortality rates } \\
\text { from commercial } \\
\text { and short tows } \\
\text { were } 45 \% \text { ( } \mathrm{n}= \\
124 \text { ) and } 13 \% \text { ( } \mathrm{n}= \\
38 \text { ), respectively. } \\
\text { Skates rated as } \\
\text { 'poor', 'moderate' } \\
\text { and 'good' health } \\
\text { showed mortality } \\
\text { rates of } 79 \%, 16 \% \\
\text { and } 5 \% \text {. } \\
\text { The proportion of } \\
\text { skates deemed of } \\
\text { 'good' health in } \\
\text { commercial tows } \\
\text { ranged from 3-6\% } \\
\text { (R. brachyura, } R . \\
\text { microocellata and } \\
R . \text { montagui) to } \\
35 \% \text { ( } R \text {. clavata). } \\
\text { A greater } \\
\text { proportion of } \\
\text { skates (18-69\%) } \\
\text { were considered } \\
\text { to be in 'good' } \\
\text { condition in } \\
\text { shorter tows. } \\
\text { Cod-end weight, } \\
\text { species and sex all } \\
\text { found to be } \\
\text { important factors } \\
\text { influencing health } \\
\text { state. }\end{array}$ & $\begin{array}{l}\text { Enever et al. } \\
(2009)\end{array}$ \\
\hline
\end{tabular}




\begin{tabular}{|c|c|c|c|c|c|c|c|c|}
\hline Fishery & Study area & Approach & Details & Family & Species & AVM & Key findings & Source \\
\hline \multirow[t]{2}{*}{$\begin{array}{l}\text { Trawls with different } \\
\text { designs of cod-end } \\
\text { ( } 80 \text { and } 100 \mathrm{~mm} \\
\text { diamond mesh and } \\
100 \mathrm{~mm} \text { square } \\
\text { mesh) }\end{array}$} & $\begin{array}{l}\text { NE Atlantic } \\
\text { (Bristol } \\
\text { Channel) }\end{array}$ & Vitality & $\begin{array}{l}\text { Health state } \\
\text { assessed visually for } \\
\text { vitality (poor health } \\
=1 \text {, moderate } \\
\text { health }=2 \text {; good } \\
\text { health }=3 \text { ). }\end{array}$ & Rajidae & $\begin{array}{l}\text { Various skates, including: } \\
\text { Leucoraja naevus } \\
\text { Raja brachyura } \\
\text { Raja clavata } \\
\text { Raja microocellata } \\
\text { Raja montagui }\end{array}$ & - & $\begin{array}{l}80 \mathrm{~mm} \text { diamond } \\
\text { mesh: Mean } \\
\text { vitality }=1.2 ; 25 \% \\
\text { of skates with } \\
\text { vitality }>1 \\
100 \mathrm{~mm} \text { diamond } \\
\text { mesh: Mean } \\
\text { vitality }=1.3 ; 34 \% \\
\text { of skates with } \\
\text { vitality }>1 \\
100 \mathrm{~mm} \text { square } \\
\text { mesh: Mean } \\
\text { vitality = } 1.5 ; 47 \% \\
\text { of skates with } \\
\text { vitality }>1\end{array}$ & $\begin{array}{l}\text { Enever et al. } \\
(2010)\end{array}$ \\
\hline & & $\begin{array}{l}\text { Short- } \\
\text { term } \\
\text { survival }\end{array}$ & $\begin{array}{l}\text { Survival in onboard } \\
\text { holding tanks (to } \\
>48 \mathrm{~h} \text { ). }\end{array}$ & Rajidae & Raja microocellata & - & $\begin{array}{l}\text { The percentage of } \\
\text { individuals that } \\
\text { survived }>48 \mathrm{~h} \\
\text { were } 55-57 \% \text { ( } 80 \\
\mathrm{~mm} \text { cod-end), } \\
59 \%(100 \mathrm{~mm} \\
\text { diamond) and } \\
67 \% \text { (100 } \mathrm{mm} \\
\text { square mesh) }\end{array}$ & \\
\hline $\begin{array}{l}\text { Trawl and line } \\
\text { fisheries }\end{array}$ & $\begin{array}{l}\text { NW Atlantic } \\
\text { (Gulf of St } \\
\text { Lawrence) }\end{array}$ & $\begin{array}{l}\text { Vitality } \\
\text { and short- } \\
\text { term } \\
\text { survival }\end{array}$ & $\begin{array}{l}\text { Health state } \\
\text { assessed visually for } \\
\text { vitality }(1-4) \text { and } \\
\text { survival of } \\
\text { specimens held in } \\
\text { on-board tanks } \\
\text { assessed (to }>48 \mathrm{~h} \text { ). }\end{array}$ & Rajidae & $\begin{array}{l}\text { Various skates, including: } \\
\text { Amblyraja radiata } \\
\text { Leucoraja ocellata } \\
\text { Malacoraja senta }\end{array}$ & - & $\begin{array}{l}>50 \% \text { and } 70 \% \text { of } \\
\text { skates were } \\
\text { scored as } \\
\text { 'excellent' } \\
\text { following capture } \\
\text { in trawl and } \\
\text { longline, } \\
\text { respectively. Fish } \\
\text { surviving for at } \\
\text { least } 48 \mathrm{~h} \text { ranged } \\
\text { from } 42 \% \text { (vitality } \\
4 \text { ) to } 100 \% \\
\text { (vitality 1) }\end{array}$ & $\begin{array}{l}\text { Benoît et al. } \\
\text { (2010a) }\end{array}$ \\
\hline
\end{tabular}




\begin{tabular}{|c|c|c|c|c|c|c|c|c|}
\hline Fishery & Study area & Approach & Details & Family & Species & AVM & Key findings & Source \\
\hline $\begin{array}{l}\text { Bottom trawl }(2.75 \\
\text { knot tow speed; tow } \\
\text { duration of } 1-2 \mathrm{~h})\end{array}$ & $\begin{array}{l}\text { NW Atlantic } \\
\text { (Canada) }\end{array}$ & $\begin{array}{l}\text { AVM and } \\
\text { short- } \\
\text { term } \\
\text { survival }\end{array}$ & $\begin{array}{l}\text { Vitality scored at } \\
\text { capture and then } \\
\text { fish monitored in } \\
\text { on-board holding } \\
\text { tanks for } 14-110 \mathrm{~h}\end{array}$ & Rajidae & $\begin{array}{l}\text { Various skates }(\mathrm{n}=160) \text {, } \\
\text { including: } \text { Amblyraja } \\
\text { radiata } \\
\text { Leucoraja ocellata } \\
\text { Malacoraja senta }\end{array}$ & $13.75 \%$ & $\begin{array}{l}75.6 \% \text { survived } \\
\text { capture and } \\
\text { holding, and } \\
10.6 \% \text { died whilst } \\
\text { being held in } \\
\text { tanks. }\end{array}$ & $\begin{array}{l}\text { Benoît et al. } \\
(2012)\end{array}$ \\
\hline $\begin{array}{l}\text { Trawl ( } 165 \mathrm{~mm} \\
\text { diamond mesh cod- } \\
\text { end) deployed from } \\
\text { commercial vessels, } \\
\text { duration for 'control' } \\
\text { tows of } 0.25-0.33 \mathrm{~h} \text {, } \\
\text { with other tows of } \\
\text { moderate }(1.5-2 \mathrm{~h}) \\
\text { or extended ( } 3-4 \mathrm{~h}) \\
\text { duration }\end{array}$ & $\begin{array}{l}\text { NW Atlantic } \\
\text { (Massachusetts } \\
\text { and New } \\
\text { Hampshire) }\end{array}$ & $\begin{array}{l}\text { AVM and } \\
\text { short- } \\
\text { term } \\
\text { survival }\end{array}$ & $\begin{array}{l}\text { Injuries scored (1 = } \\
\text { no obvious injury; } 3 \\
\text { = extensive injury); } \\
\text { submerged net pens } \\
\text { for examining } \\
\text { survival ( } 72 \mathrm{~h}) ; \\
\text { laboratory tanks for } \\
\text { 7-day monitoring }\end{array}$ & Rajidae & $\begin{array}{l}\text { Various skates, including: } \\
\text { Amblyraja radiata } \\
\text { Leucoraja erinacea } \\
\text { Leucoraja ocellata } \\
\text { Malacoraja senta }\end{array}$ & $<1 \%$ & $\begin{array}{l}44 \% \text { injured } \\
\text { (categories } 2 \text { and } \\
3 \text { ) and <1\% skates } \\
\text { dead on capture; } \\
19 \% \text { mortality } \\
\text { over } 72 \text { h overall } \\
\text { for fish caught } \\
\text { under commercial } \\
\text { conditions } \\
\text { (ranging from 9\% } \\
\text { in winter skate to } \\
60 \% \text { in smooth } \\
\text { skate); mortality } \\
\text { over } 7 \text { day trials } \\
\text { increased to } 66 \% \\
\text { (thorny skate) and } \\
22 \% \text { (little skate) }\end{array}$ & $\begin{array}{l}\text { Mandelman et } \\
\text { al. (2013) }\end{array}$ \\
\hline $\begin{array}{l}\text { Research trawl }(17 \mathrm{~m} \\
\text { ground rope; } 44 \mathrm{~mm} \\
\text { cod-end mesh; } 2.3- \\
2.7 \text { knot trawl } \\
\text { speed). Tow duration } \\
\text { either control }(1 \mathrm{~h}) \\
\text { or 'commercial' }(3 \mathrm{~h})\end{array}$ & $\begin{array}{l}\text { Western } \\
\text { Mediterranean }\end{array}$ & $\begin{array}{l}\text { AVM and } \\
\text { short- } \\
\text { term } \\
\text { survival }\end{array}$ & $\begin{array}{l}\text { Catch processed, } \\
\text { skates left on deck } \\
\text { for } 10-20 \text { minutes } \\
\text { and then placed in } \\
\text { holding tanks. } \\
\text { Health state } \\
\text { recorded on a 4- } \\
\text { point scale }(0= \\
\text { dead; } 1=\text { poor } \\
\text { health; } 2= \\
\text { moderate health; } 3 \\
=\text { good health). } \\
\text { Short-term survival } \\
\text { checked over } 48 \mathrm{~h}\end{array}$ & Rajidae & Raja clavata $(\mathrm{n}=120)$ & $1.7 \%$ & $\begin{array}{l}90.8 \% \text { of } \\
\text { specimens in } \\
\text { moderate or good } \\
\text { health. Specimens } \\
\text { caught in short } \\
\text { tows ( } \mathrm{n}=52 ; 98 \% \\
\text { in moderate/good } \\
\text { health) were in a } \\
\text { better health } \\
\text { state than those } \\
\text { taken in } \\
\text { 'commercial' tows } \\
\text { ( } \mathrm{n}=68 ; 85 \% \text { in } \\
\text { moderate/good } \\
\text { health). The } \\
\text { overall proportion } \\
\text { alive after } 48 \mathrm{~h} \\
\text { was } 80.8 \% \text {. }\end{array}$ & $\begin{array}{l}\text { Saygu \& Deval } \\
\text { (2014) }\end{array}$ \\
\hline
\end{tabular}




\begin{tabular}{|c|c|c|c|c|c|c|c|c|}
\hline Fishery & Study area & Approach & Details & Family & Species & AVM & Key findings & Source \\
\hline & & & & & Raja miraletus $(\mathrm{n}=68)$ & $26.5 \%)$ & $\begin{array}{l}\text { Only } 42.6 \% \text { of } \\
\text { specimens were } \\
\text { in moderate or } \\
\text { good health. The } \\
\text { overall proportion } \\
\text { alive after } 48 \mathrm{~h} \\
\text { was } 20.6 \% . \\
\end{array}$ & \\
\hline $\begin{array}{l}\text { Pilbara trawl fishery } \\
\text { (trawl depths of 50- } \\
100 \mathrm{~m} \text {, tow } \\
\text { durations of ca. } 2.5 \\
\text { h) }\end{array}$ & Australia & AVM & & - & $\begin{array}{l}\text { Sharks (aggregated, } n=66 \text { ) } \\
\text { Batoids (aggregated, } n= \\
\text { 53) }\end{array}$ & $\begin{array}{r}90.9 \% \\
66 \%\end{array}$ & $\begin{array}{l}\text { Data reported for } \\
\text { higher taxonomic } \\
\text { groups only }\end{array}$ & $\begin{array}{l}\text { Jaiteh et al. } \\
\text { (2015) }\end{array}$ \\
\hline \multicolumn{9}{|c|}{ BEAM TRAWL AND DREDGE } \\
\hline $\begin{array}{l}\text { Beam trawl ( } 4 \mathrm{~m} \\
\text { beam, chain mat, } 80 \\
\mathrm{~mm} \text { diamond mesh } \\
\text { cod-end; } 0.5 \mathrm{~h} \text { tows) }\end{array}$ & $\begin{array}{l}\text { NE Atlantic } \\
\text { (Irish Sea) }\end{array}$ & $\begin{array}{l}\text { AVM and } \\
\text { short- } \\
\text { term } \\
\text { survival }\end{array}$ & $\begin{array}{l}\text { Animals caught } \\
\text { from beam trawl } \\
\text { placed in on-board } \\
\text { tanks with fresh } \\
\text { seawater supply and } \\
\text { assessed for up } 5 \\
\text { days }\end{array}$ & $\begin{array}{l}\text { Rajidae } \\
\text { Scyliorhinidae }\end{array}$ & $\begin{array}{l}\text { Leucoraja naevus }(\mathrm{n}=32 \text { ) } \\
\text { Scyliorhinus canicula }(\mathrm{n}= \\
42 \text { ) }\end{array}$ & $\begin{array}{r}0 \% \\
0-3 \%\end{array}$ & $\begin{array}{l}\text { No AVM, but } 41 \% \\
\text { dead after } 5 \text { days } \\
90-94 \% \text { of fish } \\
\text { survived periods } \\
\text { of } 120 \mathrm{~h}\end{array}$ & $\begin{array}{l}\text { Kaiser and } \\
\text { Spencer (1995) }\end{array}$ \\
\hline $\begin{array}{l}\text { Scallop dredge } \\
\text { (commercial fishery } \\
\text { and experimental) }\end{array}$ & $\begin{array}{l}\text { NW Atlantic } \\
\text { (Gulf of St } \\
\text { Lawrence) }\end{array}$ & Vitality & $\begin{array}{l}\text { Health state } \\
\text { assessed visually for } \\
\text { vitality }(1-4) \text { and } \\
\text { degree of injury (1- } \\
\text { 3) }\end{array}$ & Rajidae & $\begin{array}{l}\text { Leucoraja ocellata }(\mathrm{n}=49 \\
\text { in commercial fishery; } \mathrm{n}= \\
77 \text { in experimental fishery) }\end{array}$ & - & $\begin{array}{l}\text { In both } \\
\text { commercial and } \\
\text { experimental } \\
\text { conditions, >80\% } \\
\text { of winter skate } \\
\text { were scored as } \\
\text { 'excellent' } \\
\text { condition and } \\
>70 \% \text { with 'no } \\
\text { injury'. Fish in } \\
\text { poor or moribund } \\
\text { condition } \\
\text { accounted for } \\
\text { only } 8.2 \% \\
\text { (commercial) and } \\
4 \% \text { (experimental) } \\
\text { of specimens }\end{array}$ & $\begin{array}{l}\text { Benoît et al. } \\
\text { (2010b) }\end{array}$ \\
\hline
\end{tabular}




\begin{tabular}{|c|c|c|c|c|c|c|c|c|}
\hline Fishery & Study area & Approach & Details & Family & Species & AVM & Key findings & Source \\
\hline $\begin{array}{l}\text { Beam trawls } \\
\text { deployed from } \\
\text { research vessel }\end{array}$ & $\begin{array}{l}\text { NE Atlantic } \\
\text { (North Sea) }\end{array}$ & $\begin{array}{l}\text { Short- } \\
\text { term } \\
\text { survival }\end{array}$ & $\begin{array}{l}\text { Fish maintained in } \\
\text { on-board holding } \\
\text { tanks for periods of } \\
\text { up to } 65-80 \mathrm{~h}\end{array}$ & Rajidae & $\begin{array}{l}\text { Data collected at family } \\
\text { level }(n=249)\end{array}$ & - & $\begin{array}{l}72 \% \text { of skates } \\
\text { survived }\end{array}$ & $\begin{array}{l}\text { Depestele et al. } \\
\text { (2014) }\end{array}$ \\
\hline $\begin{array}{l}\text { Scallop dredges } \\
\text { (commercial vessels } \\
\text { with standard fishing } \\
\text { operations; } 15-15.5^{\prime} \\
\text { commercial scallop } \\
\text { dredges with 4" rings } \\
\text { and } 10^{\prime \prime} \text { square mesh } \\
\text { top; } 0.17-1.5 \text { h tows) }\end{array}$ & NW Atlantic & $\begin{array}{l}\text { Vitality } \\
\text { and short- } \\
\text { term } \\
\text { survival }\end{array}$ & $\begin{array}{l}\text { Condition reported } \\
(1=\text { minimal injuries } \\
\text { to } 3=\text { extensive } \\
\text { injuries). Sub- } \\
\text { samples held in } \\
\text { survival tanks to } \\
\text { examine post- } \\
\text { release mortality, } \\
\text { with specimens } \\
\text { from } 10 \text { min tows } \\
\text { acting as control fish }\end{array}$ & Rajidae & $\begin{array}{l}\text { Leucoraja erinacea }(\mathrm{n}= \\
2634 \text { for condition } / 179 \\
\text { for post-release mortality) } \\
\text { Leucoraja ocellata ( } \mathrm{n}= \\
1313 \text { / 116) } \\
\text { Dipturus laevis }(\mathrm{n}=269 \text { / } \\
\text { 39) }\end{array}$ & $\begin{array}{r}- \\
- \\
- \\
- \\
-\end{array}$ & $\begin{array}{l}\text { The proportion of } \\
\text { fish with minor, } \\
\text { moderate and } \\
\text { extensive injuries } \\
\text { were } 22,49 \text { and } \\
29 \% \text {, respectively. } \\
\text { Post-release } \\
\text { mortality } \\
\text { estimated at } \\
49.1 \% \text { over } 72 \mathrm{~h} \text {. } \\
\text { The proportion of } \\
\text { fish with minor, } \\
\text { moderate and } \\
\text { extensive injuries } \\
\text { were } 19,52 \text { and } \\
29 \%, \text { respectively. } \\
\text { Post-release } \\
\text { mortality } \\
\text { estimated at } \\
65.2 \% \text { over } 72 \mathrm{~h} \text {. } \\
\text { The proportion of } \\
\text { fish with minor, } \\
\text { moderate and } \\
\text { extensive injuries } \\
\text { were } 11,58 \text { and } \\
31 \% \text {, respectively }\end{array}$ & $\begin{array}{l}\text { Rudders et al. } \\
\text { (2015) }\end{array}$ \\
\hline \multicolumn{9}{|c|}{ GILLNET AND TANGLE NET } \\
\hline $\begin{array}{l}\text { Protective nets set } \\
\text { off beaches. Soak } \\
\text { times generally } 12- \\
48 \mathrm{~h}\end{array}$ & $\begin{array}{l}\text { Australia (New } \\
\text { South Wales) }\end{array}$ & AVM & $\begin{array}{l}\text { Information on the } \\
\text { proportion alive } \\
\text { recorded, but no } \\
\text { specific information } \\
\text { in relation to soak } \\
\text { time }\end{array}$ & $\begin{array}{l}\text { Hexanchidae } \\
\text { Squatinidae } \\
\text { Heterodontidae } \\
\text { Orectolobidae } \\
\text { Odontaspididae } \\
\text { Alopiidae } \\
\text { Lamnidae }\end{array}$ & $\begin{array}{l}\text { Notorynchus cepedianus }(\mathrm{n} \\
=54) \\
\text { Squatina australis }(\mathrm{n}= \\
651) \\
\text { Heterodontus spp. }(\mathrm{n}=60) \\
\text { Orectolobus spp. }(\mathrm{n}=13) \\
\text { Carcharias taurus }(\mathrm{n}=62) \\
\text { Alopias spp. }(\mathrm{n}=22) \\
\text { Carcharodon carcharias }(\mathrm{n} \\
=185)\end{array}$ & $\begin{array}{r}85.1 \% \\
34.4 \% \\
3.3 \% \\
15.4 \% \\
41.3 \% \\
90.9 \% \\
49.2 \%\end{array}$ & $\begin{array}{l}\text { Values relate to } \\
\text { the percentage } \\
\text { recovered dead } \\
\text { from protective } \\
\text { shark nets, which } \\
\text { is analogous to } \\
\text { AVM }\end{array}$ & $\begin{array}{l}\text { Reid and Krogh } \\
\text { (1992) }\end{array}$ \\
\hline
\end{tabular}




\begin{tabular}{|c|c|c|c|c|c|c|c|c|}
\hline Fishery & Study area & Approach & Details & Family & Species & AVM & Key findings & Source \\
\hline & & & & & Isurus spp. $(\mathrm{n}=17)$ & $90.9 \%$ & & \\
\hline & & & & Carcharhinidae & $\begin{array}{l}\text { Carcharhinus spp. }(n= \\
724)\end{array}$ & $61 \%$ & & \\
\hline & & & & Sphyrnidae & Sphyrna spp. $(\mathrm{n}=2031)$ & $98.3 \%$ & & \\
\hline $\begin{array}{l}\text { Scientific fishing with } \\
\text { gillnet ( } 10 \mathrm{~cm} \text { stretch } \\
\text { mesh, soak time ca. } \\
12 \mathrm{~h} \text {, but nets } \\
\text { checked every } 0.25 \\
\text { h) }\end{array}$ & Bahamas & AVM & $\begin{array}{l}\text { Mortality recorded } \\
\text { after capture, } \\
\text { handling, tagging } \\
\text { and maintenance in } \\
\text { a pen }\end{array}$ & Carcharhinidae & $\begin{array}{l}\text { Negaprion brevirostris }(\mathrm{n}= \\
655)\end{array}$ & $0-11.1 \%$ & $\begin{array}{l}\text { Overall, handling } \\
\text { mortality } \\
\text { (including } \\
\text { capture) of } \\
\text { juvenile lemon } \\
\text { sharks was } 3.5 \% \\
\text { (ranging from 0- } \\
11.1 \% \text { for the } \\
\text { various study sites } \\
\text { and years } \\
\text { reported). }\end{array}$ & $\begin{array}{l}\text { Gruber et al. } \\
\text { (2001) }\end{array}$ \\
\hline \multirow[t]{3}{*}{$\begin{array}{l}\text { Gillnet }(11.75-15.25 \\
\text { mm stretched mesh } \\
\text { size; } 0.75-1.0 \text { h soak } \\
\text { time; depth }<3 \mathrm{~m}\end{array}$} & $\begin{array}{l}\text { NW Atlantic } \\
\text { (South-west } \\
\text { Florida) }\end{array}$ & $\begin{array}{l}\text { AVM and } \\
\text { blood } \\
\text { sampling }\end{array}$ & $\begin{array}{l}\text { Sharks sampled in } \\
\text { research } \\
\text { programme, with } \\
\text { blood samples taken } \\
\text { and condition } \\
\text { recorded (5-point }\end{array}$ & Carcharhinidae & $\begin{array}{l}\text { Carcharhinus limbatus }(\mathrm{n}= \\
\text { 33) }\end{array}$ & $24.2 \%$ & $\begin{array}{l}39.4 \% \text { in good or } \\
\text { fair condition and } \\
36.4 \% \text { in poor or } \\
\text { very poor } \\
\text { condition. }\end{array}$ & $\begin{array}{l}\text { Manire et al. } \\
\text { (2001) }\end{array}$ \\
\hline & & & scale) & & $\begin{array}{l}\text { Carcharhinus leucas }(\mathrm{n}= \\
\text { 27) }\end{array}$ & $18.5 \%$ & $\begin{array}{l}74.1 \% \text { in good or } \\
\text { fair condition and } \\
7.4 \% \text { in poor } \\
\text { condition }\end{array}$ & \\
\hline & & & & Sphyrnidae & Sphyrna tiburo $(\mathrm{n}=39)$ & $30.8 \%$ & $\begin{array}{l}35.9 \% \text { in good or } \\
\text { fair condition and } \\
33.3 \% \text { in poor or } \\
\text { very poor } \\
\text { condition }\end{array}$ & \\
\hline $\begin{array}{l}\text { Commercial gillnets } \\
\text { (>80 mm stretched } \\
\text { mesh) set overnight }\end{array}$ & $\begin{array}{l}\text { SW Pacific } \\
\text { (New South } \\
\text { Wales) }\end{array}$ & AVM & $\begin{array}{l}\text { Commercial catches } \\
\text { examined and } \\
\text { proportion of fish } \\
\text { discarded alive } \\
\text { recorded }\end{array}$ & Dasyatidae & Dasyatis sp. $(\mathrm{n}=112)$ & $7.2 \%$ & & Gray (2002) \\
\hline $\begin{array}{l}\text { Commercial gillnets } \\
\text { (6-6.5" mesh; mean } \\
\text { soak time of } 8.2 \mathrm{~h} ; \\
\text { fishing depths of } 17-\end{array}$ & South Australia & AVM & $\begin{array}{l}\text { AVM recorded for } \\
\text { two fishing grounds } \\
\text { (Bass Strait and } \\
\text { South Australia) }\end{array}$ & $\begin{array}{l}\text { Hexanchidae } \\
\text { Squalidae }\end{array}$ & $\begin{array}{l}\text { Notorynchus cepedianus ( } \mathrm{n} \\
=83 \text { ) } \\
\text { Squalus megalops }(\mathrm{n}= \\
325) \\
\text { Squalus acanthias }(\mathrm{n}=1)\end{array}$ & $\begin{array}{r}79-83 \% \\
0-6 \% \\
(0 \%)\end{array}$ & & $\begin{array}{l}\text { Walker et al. } \\
(2005)\end{array}$ \\
\hline
\end{tabular}




\begin{tabular}{|c|c|c|c|c|c|c|c|c|}
\hline Fishery & Study area & Approach & Details & Family & Species & AVM & Key findings & Source \\
\hline \multirow[t]{18}{*}{$\begin{array}{l}130 \mathrm{~m} \text { (mostly }<80 \\
\mathrm{~m})\end{array}$} & & & & Heterodontidae & $\begin{array}{l}\text { Heterodontus } \\
\text { portusjacksoni }(\mathrm{n}=778)\end{array}$ & $0 \%$ & & \\
\hline & & & & Squatinidae & Squatina australis $(n=43)$ & $11-33 \%$ & & \\
\hline & & & & Orectolobidae & $\begin{array}{l}\text { Orectolobus maculatus ( } \mathrm{n} \\
=4 \text { ) }\end{array}$ & $(0 \%)$ & & \\
\hline & & & & Alopiidae & Alopias vulpinus $(\mathrm{n}=20)$ & $60 \%$ & & \\
\hline & & & & Lamnidae & Isurus oxyrinchus $(\mathrm{n}=4)$ & $(75 \%)$ & & \\
\hline & & & & Pristiophoridae & $\begin{array}{l}\text { Pristiophorus cirratus }(\mathrm{n}= \\
\text { 1051) }\end{array}$ & $7-23 \%$ & & \\
\hline & & & & & $\begin{array}{l}\text { Pristiophorus nudipinnis ( } \mathrm{n} \\
=250 \text { ) }\end{array}$ & $22-33 \%$ & & \\
\hline & & & & Scyliorhinidae & $\begin{array}{l}\text { Cephaloscyllium laticeps ( } \mathrm{n} \\
=1034 \text { ) }\end{array}$ & $0 \%$ & & \\
\hline & & & & Triakidae & Furgaleus macki $(\mathrm{n}=1)$ & - & & \\
\hline & & & & & $\begin{array}{l}\text { Galeorhinus galeus }(\mathrm{n}= \\
\text { 187) }\end{array}$ & $2-70 \%$ & & \\
\hline & & & & & $\begin{array}{l}\text { Mustelus antarcticus ( } \mathrm{n}= \\
4625)\end{array}$ & $53-60 \%$ & & \\
\hline & & & & Carcharhinidae & $\begin{array}{l}\text { Carcharhinus brachyurus } \\
(n=42)\end{array}$ & $0 \%$ & & \\
\hline & & & & Sphyrnidae & Sphyrna zygaena $(\mathrm{n}=77)$ & $3 \%$ & & \\
\hline & & & & Rhinobatidae & $\begin{array}{l}\text { Aptychotrema vincentiana } \\
(\mathrm{n}=6)\end{array}$ & $(16.6 \%)$ & & \\
\hline & & & & Rajidae & Rajidae indet. $(n=5)$ & $(0 \%)$ & & \\
\hline & & & & Urolophidae & $\begin{array}{l}\text { Urolophus paucimaculatus } \\
(\mathrm{n}=43)\end{array}$ & $23-50 \%$ & $\begin{array}{l}\text { AVM ranged from } \\
23 \%(n=41) \text { to } \\
50 \%(n=2) \text { in the } \\
\text { two fishing areas } \\
\text { studied }\end{array}$ & \\
\hline & & & & Myliobatidae & $\begin{array}{l}\text { Myliobatis australis }(\mathrm{n}= \\
94)\end{array}$ & $9-21 \%$ & & \\
\hline & & & & Callorhinchidae & $\begin{array}{l}\text { Callorhinchus milii }(\mathrm{n}= \\
763)\end{array}$ & $23-29 \%$ & & \\
\hline
\end{tabular}




\begin{tabular}{|c|c|c|c|c|c|c|c|c|}
\hline Fishery & Study area & Approach & Details & Family & Species & AVM & Key findings & Source \\
\hline \multirow[t]{2}{*}{$\begin{array}{l}\text { Scientific gillnet } \\
\text { surveys, soak times } \\
\text { usually } 1 \mathrm{~h}\end{array}$} & $\begin{array}{l}\text { NW Atlantic } \\
\text { (Gulf of } \\
\text { Mexico) }\end{array}$ & $\begin{array}{l}\text { AVM and } \\
\text { tagging }\end{array}$ & $\begin{array}{l}\text { Vitality scored (1 = } \\
\text { Good, } 4=\text { very poor, } \\
5=\text { dead). Return } \\
\text { rates of tagged fish } \\
\text { of different vitality } \\
\text { scores used to } \\
\text { model relative } \\
\text { survival }\end{array}$ & Carcharhinidae & Carcharhinus limbatus & $40 \%$ & $\begin{array}{l}\text { Approximately } \\
60 \% \text { of individuals } \\
\text { were tagged on } \\
\text { capture (vitality } \\
1-4 \text { ) and } 40 \% \\
\text { dead. Of the } \\
\text { tagged fish, a } \\
\text { further } 31 \% \text { of } \\
\text { fish tagged and } \\
\text { released were } \\
\text { estimated to have } \\
\text { died subsequently } \\
\text { (overall mortality } \\
\text { of } 58 \% \text { ). }\end{array}$ & $\begin{array}{l}\text { Hueter et al. } \\
(2006)\end{array}$ \\
\hline & & & & Sphyrnidae & Sphyrna tiburo & $37 \%$ & $\begin{array}{l}\text { Approximately } \\
63 \% \text { of individuals } \\
\text { were tagged on } \\
\text { capture (vitality } \\
1-4 \text { ) and } 37 \% \\
\text { dead. Of the } \\
\text { tagged fish, a } \\
\text { further } 40 \% \text { of } \\
\text { fish tagged and } \\
\text { released were } \\
\text { estimated to have } \\
\text { died subsequently } \\
\text { (overall mortality } \\
\text { of } 62 \% \text { ). }\end{array}$ & \\
\hline
\end{tabular}




\begin{tabular}{|c|c|c|c|c|c|c|c|c|}
\hline Fishery & Study area & Approach & Details & Family & Species & AVM & Key findings & Source \\
\hline $\begin{array}{l}\text { Gillnet (101-165 mm } \\
\text { mesh sizes; } 19.5- \\
23.5 \mathrm{~h} \text { soak time) }\end{array}$ & NW Atlantic & $\begin{array}{l}\text { AVM and } \\
\text { short- } \\
\text { term } \\
\text { survival }\end{array}$ & $\begin{array}{l}\text { Immediate post- } \\
\text { capture mortality } \\
\text { recorded, live fish } \\
\text { maintained in sea } \\
\text { cages for } 48 \mathrm{~h}\end{array}$ & Squalidae & $\begin{array}{l}\text { Squalus acanthias }(\mathrm{n}= \\
2284)\end{array}$ & $17.5 \%$ & $\begin{array}{l}\text { The majority of } \\
\text { captured } \\
\text { specimens had } \\
\text { evident damage } \\
\text { from gillnets, but } \\
\text { a lower } \\
\text { proportion had } \\
\text { other damage (c.f. } \\
\text { trawl caught } \\
\text { specimens). } \\
\text { Evidence of } \\
\text { females aborting } \\
\text { young. Of the } \\
\text { specimens ( } n= \\
\text { 480) held in sea } \\
\text { cages, 17-33\% } \\
\text { died. Overall } \\
\text { gillnet mortality } \\
\text { was 55\%. }\end{array}$ & Rulifson (2007) \\
\hline $\begin{array}{l}\text { Gillnets deployed } \\
\text { from commercial } \\
\text { inshore vessels. } \\
\text { Fixed tangle nets } \\
\text { were soaked } \\
\text { overnight; drift } \\
\text { trammel nets fished } \\
\text { for 1-3 h } \\
\end{array}$ & $\begin{array}{l}\text { NE Atlantic } \\
\text { (southern } \\
\text { North Sea) }\end{array}$ & $\begin{array}{l}\text { AVM and } \\
\text { tagging }\end{array}$ & $\begin{array}{l}\text { Health state } \\
\text { recorded on a three } \\
\text { point (lively, } \\
\text { sluggish, dead) and } \\
\text { fish tagged and } \\
\text { released }\end{array}$ & Rajidae & Raja clavata $(\mathrm{n}=975)$ & $0-2 \%$ & $\begin{array}{l}\text { AVM }=2 \% \text { for the } \\
\text { vessel with } \\
\text { overnight soak } \\
\text { times. No- } \\
\text { mortality } \\
\text { observed in drift } \\
\text { trammel nets with } \\
\text { short soak times }\end{array}$ & $\begin{array}{l}\text { Ellis et al. } \\
\text { (2008a) }\end{array}$ \\
\hline $\begin{array}{l}\text { Chartered surveys on } \\
\text { board two } \\
\text { commercial } \\
\text { gillnetters; } \\
\text { commercial trammel } \\
\text { nets and gillnets } \\
\text { deployed for } \\
\text { different soak times }\end{array}$ & $\begin{array}{l}\text { NE Atlantic } \\
\text { (Celtic Sea) }\end{array}$ & AVM & $\begin{array}{l}\text { Vitality scored on a } \\
\text { 5-point scale (lively, } \\
\text { sluggish, very } \\
\text { sluggish, dead and } \\
\text { scavenged) }\end{array}$ & Squalidae & $\begin{array}{l}\text { Squalus acanthias }(\mathrm{n}= \\
388)\end{array}$ & $22.5-38.5 \%$ & $\begin{array}{l}\text { AVM }=22.5- \\
38.5 \%(n=384) \\
\text { after } 11-27 \mathrm{~h} \\
\text { soak times. } \\
\text { Sample size }(n= \\
\text { 4) limited in sets } \\
\text { with a longer soak } \\
\text { time }\end{array}$ & $\begin{array}{l}\text { Bendall et al. } \\
(2012)\end{array}$ \\
\hline
\end{tabular}




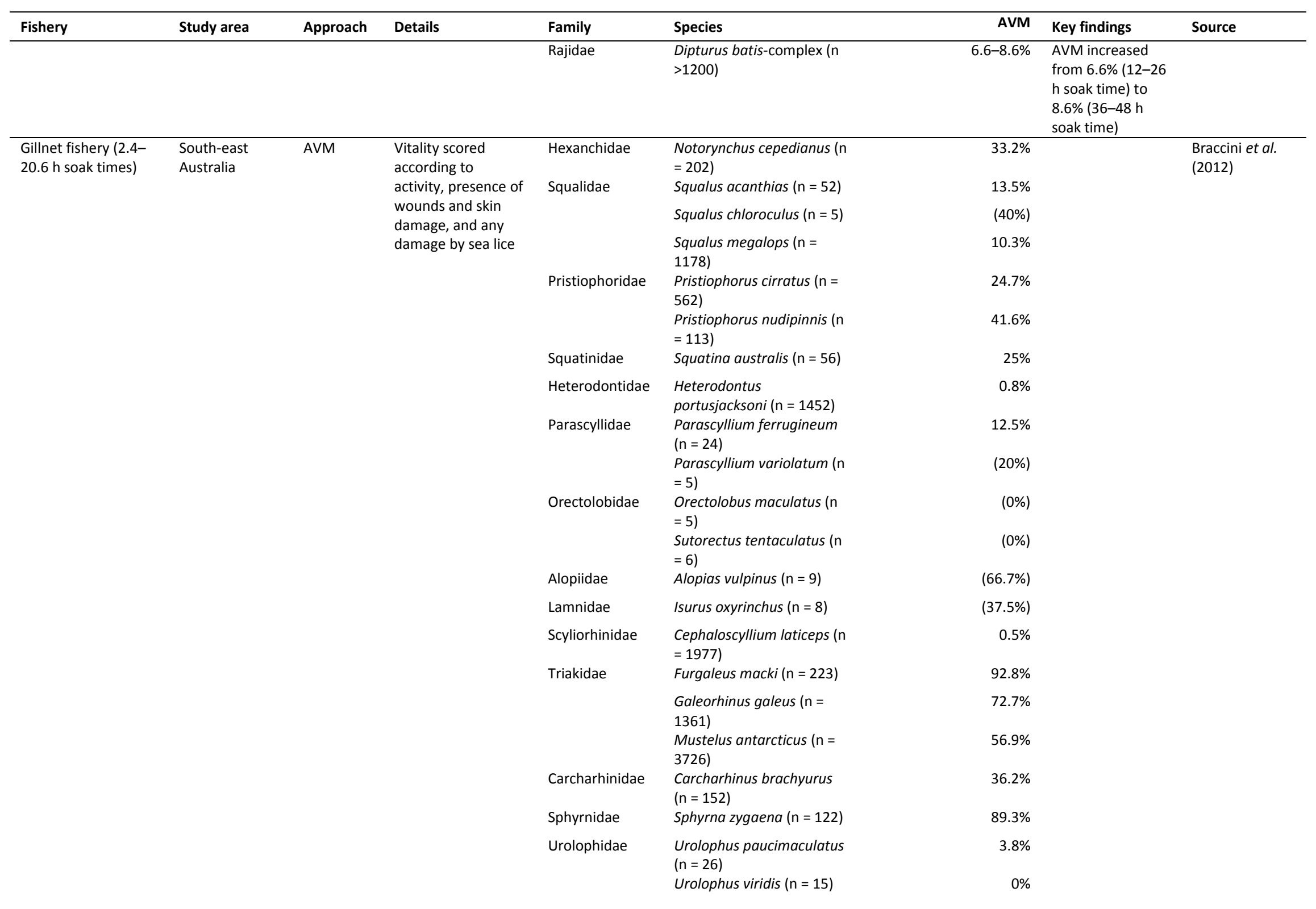




\begin{tabular}{|c|c|c|c|c|c|c|c|c|}
\hline Fishery & Study area & Approach & Details & Family & Species & AVM & Key findings & Source \\
\hline & & & & Myliobatidae & $\begin{array}{l}\text { Myliobatis australis }(\mathrm{n}= \\
133)\end{array}$ & $5.3 \%$ & & \\
\hline $\begin{array}{l}\text { Commercial gillnets, } \\
\text { including set gillnets } \\
\text { (>89 mm; variable } \\
\text { soak times) and drift } \\
\text { gillnets ( } 89-150 \mathrm{~mm} \text {; } \\
4-12 \text { h soak times) }\end{array}$ & $\begin{array}{l}\text { California } \\
\text { (Eastern Pacific) }\end{array}$ & $\begin{array}{l}\text { AVM and } \\
\text { PRM }\end{array}$ & $\begin{array}{l}\text { PRM quantified } \\
\text { from satellite and } \\
\text { acoustic tags }\end{array}$ & Lamnidae & Carcharodon carcharias & $20-68 \%$ & $\begin{array}{l}\text { Average annual } \\
\text { AVM for sharks } \\
\text { caught in gillnet } \\
\text { fisheries was } 44 \pm \\
24 \% \text {. Mortality } \\
\text { increased with } \\
\text { soak time. Post- } \\
\text { release mortality } \\
(n=28) \text { was } 7.1 \%\end{array}$ & $\begin{array}{l}\text { Lyons et al. } \\
\text { (2013) }\end{array}$ \\
\hline \multirow[t]{2}{*}{$\begin{array}{l}\text { Commercial and } \\
\text { recreational gillnets } \\
\text { (graball nets of } 114 \\
\mathrm{~mm} \text { mesh size; } \\
\text { mullet nets of } 64 \\
\mathrm{~mm} \text { mesh size). Soak } \\
\text { time ranged from 2- } \\
24 \mathrm{~h}\end{array}$} & Tasmania & $\begin{array}{l}\text { AVM and } \\
\text { short- } \\
\text { term } \\
\text { survival }\end{array}$ & $\begin{array}{l}\text { Vitality recorded (1 } \\
=\text { lively, no visible } \\
\text { damage, } 2=\text { lively, } \\
\text { minor damage, } 3= \\
\text { alive, moderate } \\
\text { damage, } 4=\text { alive } \\
\text { but poor condition, } \\
5=\text { dead) for various } \\
\text { fish species. Some } \\
\text { species were also } \\
\text { used in tank } \\
\text { experiments to } \\
\text { determine delayed } \\
\text { mortality. }\end{array}$ & Squalidae & $\begin{array}{l}\text { Squalus acanthias }(\mathrm{n}= \\
502)\end{array}$ & $7-18 \%$ & $\begin{array}{l}\text { Usually alive but } \\
\text { damaged. AVM } \\
\text { ranged from } 7 \% \\
\text { (soak time } \leq 8 \mathrm{~h}, \mathrm{n} \\
=270 \text { ) to } 18 \% \\
\text { (overnight sets, } \mathrm{n} \\
=232 \text { ). Fish in } \\
\text { poor condition or } \\
\text { dead (stages } 4 \\
\text { and } 5 \text { ) accounted } \\
\text { for } 21 \% \text { and } 33 \% \\
\text { of specimens for } \\
\text { short and } \\
\text { overnight sets. } \\
\text { Post-release } \\
\text { survival estimated } \\
\text { at } 77-86 \% .\end{array}$ & $\begin{array}{l}\text { Lyle et al. } \\
\text { (2014) }\end{array}$ \\
\hline & & & & Scyliorhinidae & $\begin{array}{l}\text { Cephaloscyllium laticeps ( } \mathrm{n} \\
=990 \text { ) }\end{array}$ & $0 \%$ & $\begin{array}{l}\text { No AVM }(n=990) \\
\text { and no delayed } \\
\text { mortality }(n=71) . \\
\text { Post-release } \\
\text { survival estimated } \\
\text { at } 100 \% .\end{array}$ & \\
\hline
\end{tabular}


Family

Rajidae

Zearaja maugeana $(\mathrm{n}=$

177) and

Raja whitleyi $(\mathrm{n}=61)$

Urolophus cruciatus $(\mathrm{n}=$

30) and U. paucimaculatus

$(\mathrm{n}=33$ )

AVM

$24 \%$

$24 \%$

ey findings

Usually alive but

damaged. AVM =

$24 \%$ (all data

combined), and

whilst $57 \%$ only

had minor or

moderate damage

(condition 1-3),

$9 \%$ were in poo

condition Post-

release survival

estimated at

$58.7 \%$.

0-9\% No AVM observed

for either $Z$.

$50)$ or R. whitleyi

$(n=61)$ when

soak times were

short, with $98 \%$ of

specimens rated

as lively or with

only minor

damage.

Overnight sets

resulted in $80 \%$ of

2. maugeana $(\mathrm{n}=$

127) being lively

or with only

minor damage

and AVM was $9 \%$.

Post-release

survival was

estimated at

$>87.2 \%$.

$0 \% \quad$ No AVM

observed, with

$90 \%$ of specimens

$90 \%$ of specimens
either lively or

either lively or
with only minor

damage, although

all specimens

were caught in

soak times of $\leq 8 \mathrm{~h}$

Source 


\begin{tabular}{|c|c|c|c|c|c|c|c|c|}
\hline Fishery & Study area & Approach & Details & Family & Species & AVM & Key findings & Source \\
\hline & & & & Callorhinchidae & $\begin{array}{l}\text { Callorhinchus milii }(\mathrm{n}= \\
314)\end{array}$ & $5-20 \%$ & $\begin{array}{l}\text { Usually alive but } \\
\text { damaged. AVM } \\
\text { ranged from } 5 \% \\
\text { (soak time } \leq 3.5 \mathrm{~h} \text {, } \\
\mathrm{n}=235 \text { ) to } 20 \% \\
\text { (overnight sets, } \mathrm{n} \\
=10 \text { ). Including } \\
\text { both stages } 4 \text { and } \\
5 \text { in estimates of } \\
\text { at-vessel } \\
\text { mortality would } \\
\text { increase } \\
\text { estimates to } 10 \% \\
\text { and } 40 \% . \text { Delayed } \\
\text { mortality ranged } \\
\text { from } 8.3 \% \\
\text { (condition } 1 \text { and } \\
2 ; n=24 \text { ) to } \\
33.3 \% \text { (condition } \\
3 \text { and } 4 ; n=6 \text { ). } \\
\text { Post-release } \\
\text { survival estimated } \\
\text { at } 74-82 \% \text {. } \\
\end{array}$ & \\
\hline \multicolumn{9}{|l|}{ LONGLINE } \\
\hline \multirow{4}{*}{$\begin{array}{l}\text { Longline deployed } \\
\text { from research vessel } \\
\text { (soak times }<12 \mathrm{~h} \text { ) }\end{array}$} & \multirow[t]{4}{*}{ Pacific (Hawaii) } & \multirow[t]{4}{*}{ AVM } & & Alopiidae & Alopias spp. $(\mathrm{n}=6)$ & $(40 \%)$ & & \multirow[t]{4}{*}{ Boggs (1992) } \\
\hline & & & & Carcharhinidae & $\begin{array}{l}\text { Carcharhinus longimanus } \\
(n=26)\end{array}$ & $15 \%$ & & \\
\hline & & & & & Prionace glauca $(\mathrm{n}=21)$ & $0 \%$ & & \\
\hline & & & & Dasyatidae & $\begin{array}{l}\text { Pteroplatytrygon violacea } \\
(\mathrm{n}=8)\end{array}$ & $(12 \%)$ & & \\
\hline \multirow{3}{*}{$\begin{array}{l}\text { Commercial longline } \\
\text { vessels targeting } \\
\text { tuna, including } \\
\text { foreign- licensed and } \\
\text { foreign-chartered } \\
\text { (with } 2500-3000 \\
\text { hooks per line) and } \\
\text { domestic fleets } \\
\text { (300-2700 hooks per } \\
\text { line) }\end{array}$} & \multirow[t]{3}{*}{ New Zealand } & \multirow[t]{3}{*}{ AVM } & \multirow{3}{*}{$\begin{array}{l}\text { AVM recorded by } \\
\text { observers }\end{array}$} & \multirow[t]{2}{*}{ Lamnidae } & Isurus oxyrinchus $(\mathrm{n}=299)$ & $28.4 \%$ & & \multirow{3}{*}{$\begin{array}{l}\text { Francis et al. } \\
\text { (2001) }\end{array}$} \\
\hline & & & & & Lamna nasus $(\mathrm{n}=2370)$ & $39.2 \%$ & & \\
\hline & & & & Carcharhinidae & Prionace glauca $(\mathrm{n}=7838)$ & $13.5 \%$ & $\begin{array}{l}\text { AVM lower for } \\
\text { domestic fleet } \\
(8.3 \%) \text { than } \\
\text { observed in } \\
\text { foreign- licensed } \\
\text { and foreign- } \\
\text { chartered fleets } \\
(13.9 \%)\end{array}$ & \\
\hline
\end{tabular}




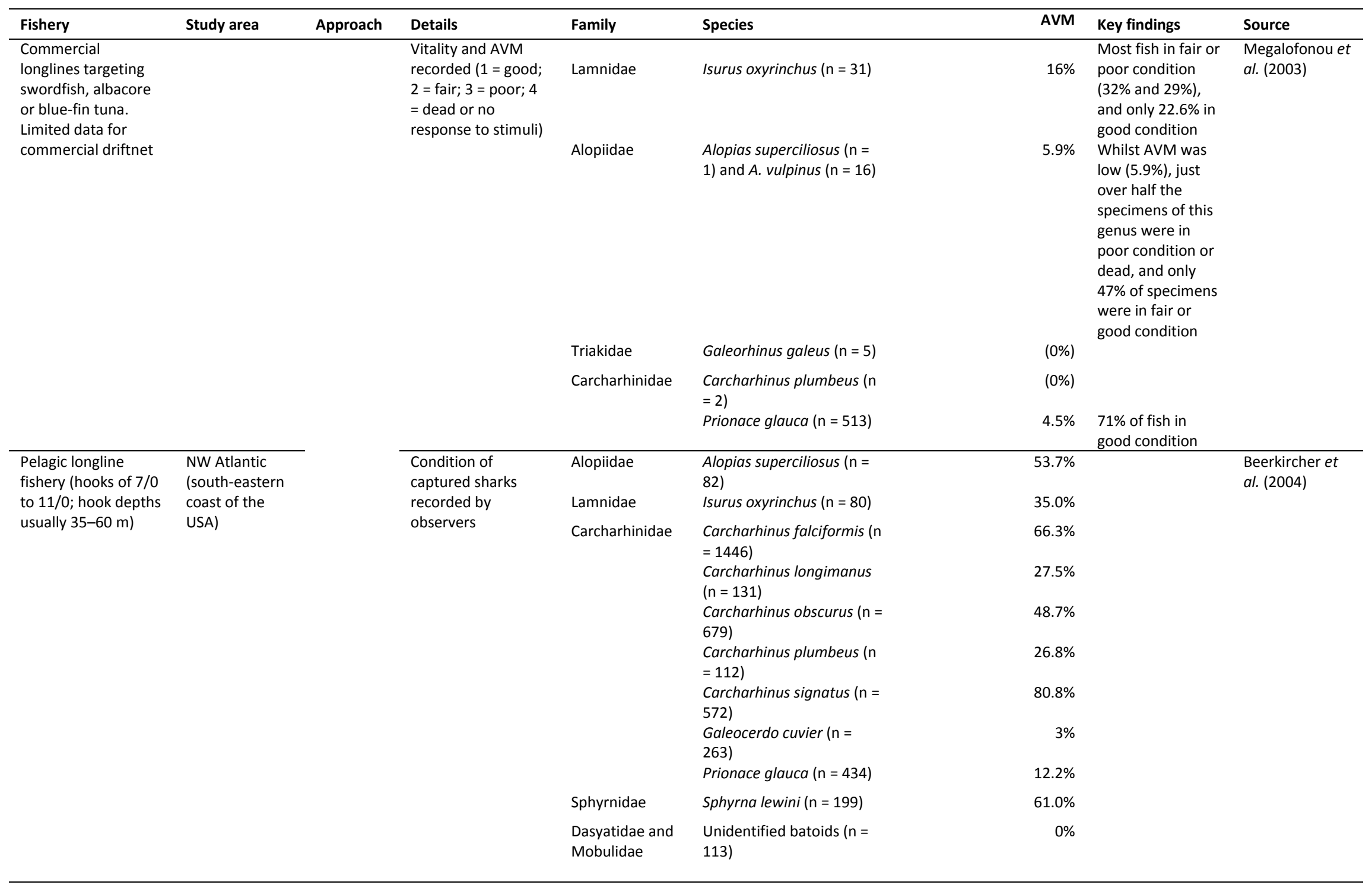




\begin{tabular}{|c|c|c|c|c|c|c|c|c|}
\hline Fishery & Study area & Approach & Details & Family & Species & AVM & Key findings & Source \\
\hline $\begin{array}{l}\text { Deep-water longlines } \\
\text { (746-1913 m depth) }\end{array}$ & $\begin{array}{l}\text { SW Atlantic } \\
\text { (South Georgia) }\end{array}$ & $\begin{array}{l}\text { Short- } \\
\text { term } \\
\text { survival }\end{array}$ & $\begin{array}{l}\text { Skates randomly } \\
\text { selected and placed } \\
\text { in deck tanks (one } \\
\text { skate per tank) for } \\
12 \mathrm{~h}\end{array}$ & Rajidae & Amblyraja sp. $(\mathrm{n}=95)$ & - & $\begin{array}{l}\text { No information on } \\
\text { AVM. Of the } \\
\text { skates that were } \\
\text { held in tanks for } \\
12 \mathrm{~h}: 44.2 \% \text { were } \\
\text { dead; } 13.7 \% \text { in } \\
\text { poor condition } \\
\text { (thought likely to } \\
\text { die); } 16.8 \% \text { in } \\
\text { moderate } \\
\text { condition and } \\
25.3 \% \text { in good } \\
\text { condition. } \\
\text { Mortality } \\
\text { increased with } \\
\text { depth }\end{array}$ & $\begin{array}{l}\text { Endicott and } \\
\text { Agnew (2004) }\end{array}$ \\
\hline $\begin{array}{l}\text { Commercial longline } \\
\text { targeting swordfish } \\
\text { and/or tuna }\end{array}$ & NW Atlantic & AVM & $\begin{array}{l}\text { Observer data for } \\
\text { fish recorded as } \\
\text { 'discarded alive' or } \\
\text { 'discarded dead' } \\
\text { analysed in relation } \\
\text { to fish size, water } \\
\text { temperature, soak } \\
\text { time, area and } \\
\text { season }\end{array}$ & Carcharhinidae & Prionace glauca & $31 \%$ & $\begin{array}{l}\text { Overall, } 69 \% \text { of } \\
\text { records were for } \\
\text { 'discarded alive'. } \\
\text { The proportion } \\
\text { released alive } \\
\text { increased with } \\
\text { increasing fish } \\
\text { length and } \\
\text { decreasing soak } \\
\text { time. }\end{array}$ & $\begin{array}{l}\text { Diaz and Serafy } \\
\text { (2005) }\end{array}$ \\
\hline $\begin{array}{l}\text { Longline deployed } \\
\text { from research vessel } \\
\text { (10-18 h soak time) }\end{array}$ & $\begin{array}{l}\text { Pacific Ocean } \\
\text { (Hawaii) }\end{array}$ & AVM & $\begin{array}{l}\text { Health assessed, } \\
\text { with } 23 \text { individuals } \\
\text { tagged with PSATs } \\
\text { and selected sharks } \\
\text { also examined for } \\
\text { blood chemistry }\end{array}$ & Carcharhinidae & Prionace glauca & ca. $5.2 \%$ & $\begin{array}{l}\text { Only nine of } 172 \\
\text { blue sharks were } \\
\text { assessed as } \\
\text { 'moribund' } \\
(5.2 \%) .\end{array}$ & $\begin{array}{l}\text { Moyes et al. } \\
(2006)\end{array}$ \\
\hline \multirow{5}{*}{$\begin{array}{l}\text { Commercial longline } \\
\text { fisheries with } \\
\text { observer coverage }\end{array}$} & \multirow{5}{*}{$\begin{array}{l}\text { NW Atlantic } \\
\text { (Gulf of } \\
\text { Mexico) }\end{array}$} & \multirow[t]{5}{*}{ AVM } & \multirow{5}{*}{$\begin{array}{l}\text { AVM assessed } \\
\text { visually (alive } \\
\text { /dead). }\end{array}$} & \multirow[t]{4}{*}{ Carcharhinidae } & $\begin{array}{l}\text { Carcharhinus limbatus }(\mathrm{n}= \\
\text { 1982) }\end{array}$ & $88 \%$ & & \multirow[t]{5}{*}{$\begin{array}{l}\text { Morgan and } \\
\text { Burgess (2007) }\end{array}$} \\
\hline & & & & & $\begin{array}{l}\text { Carcharhinus obscurus ( } \mathrm{n}= \\
662 \text { ) }\end{array}$ & $81 \%$ & & \\
\hline & & & & & $\begin{array}{l}\text { Carcharhinus plumbeus ( } \mathrm{n} \\
=8583 \text { ) }\end{array}$ & $36 \%$ & & \\
\hline & & & & & $\begin{array}{l}\text { Galeocerdo cuvier }(\mathrm{n}= \\
2466)\end{array}$ & $8.5 \%$ & & \\
\hline & & & & Sphyrnidae & Sphyrna lewini $(\mathrm{n}=455)$ & $91.4 \%$ & & \\
\hline
\end{tabular}




\begin{tabular}{|c|c|c|c|c|c|c|c|c|}
\hline Fishery & Study area & Approach & Details & Family & Species & AVM & Key findings & Source \\
\hline & & & & & $\begin{array}{l}\text { Sphyrna mokarran }(\mathrm{n}= \\
178)\end{array}$ & $93.8 \%$ & & \\
\hline $\begin{array}{l}\text { Bottom longlines } \\
\text { deployed from } \\
\text { commercial inshore } \\
\text { vessels. Soak times } \\
\text { of ca. } 2-4 \mathrm{~h}\end{array}$ & $\begin{array}{l}\text { NE Atlantic } \\
\text { (southern } \\
\text { North Sea) }\end{array}$ & AVM & $\begin{array}{l}\text { Vitality recorded on } \\
\text { a three point (lively, } \\
\text { sluggish, dead) and } \\
\text { fish tagged and } \\
\text { released }\end{array}$ & Rajidae & Raja clavata $(\mathrm{n}=817)$ & $0 \%$ & $\begin{array}{l}\text { No AVM } \\
\text { observed, } \\
\text { although fish } \\
\text { were generally } \\
\text { unhooked } \\
\text { manually. Fish } \\
\text { going through the } \\
\text { bait-stripper } \\
\text { would be more } \\
\text { likely to sustain } \\
\text { damage to the } \\
\text { jaws and mouth. }\end{array}$ & $\begin{array}{l}\text { Ellis et al. } \\
\text { (2008a) }\end{array}$ \\
\hline $\begin{array}{l}\text { Commercial longline } \\
\text { targeting swordfish } \\
\text { and/or tuna }\end{array}$ & NW Atlantic & $\begin{array}{l}\text { AVM and } \\
\text { PRM }\end{array}$ & $\begin{array}{l}\text { Estimates of both } \\
\text { AVM (scientific } \\
\text { observers) and PRM } \\
\text { (electronic tagging } \\
\text { of healthy and } \\
\text { injured fish) }\end{array}$ & Carcharhinidae & Prionace glauca & $12-20 \%$ & $\begin{array}{l}\text { Estimates of AVM } \\
\text { ranged from } 12 \% \\
\text { (observers) to } \\
20 \% \text { (scientific } \\
\text { researchers). PRM } \\
\text { reported at } 19 \% \text {. } \\
\text { Total mortality of } \\
\text { discarded blue } \\
\text { shark estimated } \\
\text { at } 29-35 \% . \\
\text { Assumed } 50 \% \\
\text { mortality for } \\
\text { shortfin mako and } \\
\text { porbeagle }\end{array}$ & $\begin{array}{l}\text { Campana et al. } \\
(2009,2011)\end{array}$ \\
\hline \multirow[t]{2}{*}{$\begin{array}{l}\text { Commercial longline } \\
\text { targeting swordfish } \\
\text { and/or tuna }\end{array}$} & \multirow[t]{2}{*}{ NW Atlantic } & \multirow[t]{2}{*}{ AVM } & \multirow[t]{2}{*}{$\begin{array}{l}\text { Observer data } \\
\text { (2001-2004) for fish } \\
\text { recorded as 'alive' } \\
\text { or 'dead' analysed } \\
\text { in relation to hook } \\
\text { type, soak time and } \\
\text { fish size. }\end{array}$} & Carcharhinidae & $\begin{array}{l}\text { Isurus oxyrinchus and } \\
\text { Lamna nasus }\end{array}$ & - & $\begin{array}{l}\text { Isurus oxyrinchus } \\
\text { of larger size had } \\
\text { increased } \\
\text { probability of } \\
\text { surviving } \\
\text { Improved survival } \\
\text { for } P \text {. glauca } \\
\text { caught on circle } \\
\text { hooks than J- } \\
\text { hooks }\end{array}$ & $\begin{array}{l}\text { Carruthers et al. } \\
\text { (2009) }\end{array}$ \\
\hline & & & & Dasyatidae & Pteroplatytrygon violacea & - & $\begin{array}{l}\text { AVM low for both } \\
\text { J-hooks }(10 \%) \text { and } \\
\text { circle hooks }(2 \%)\end{array}$ & \\
\hline
\end{tabular}




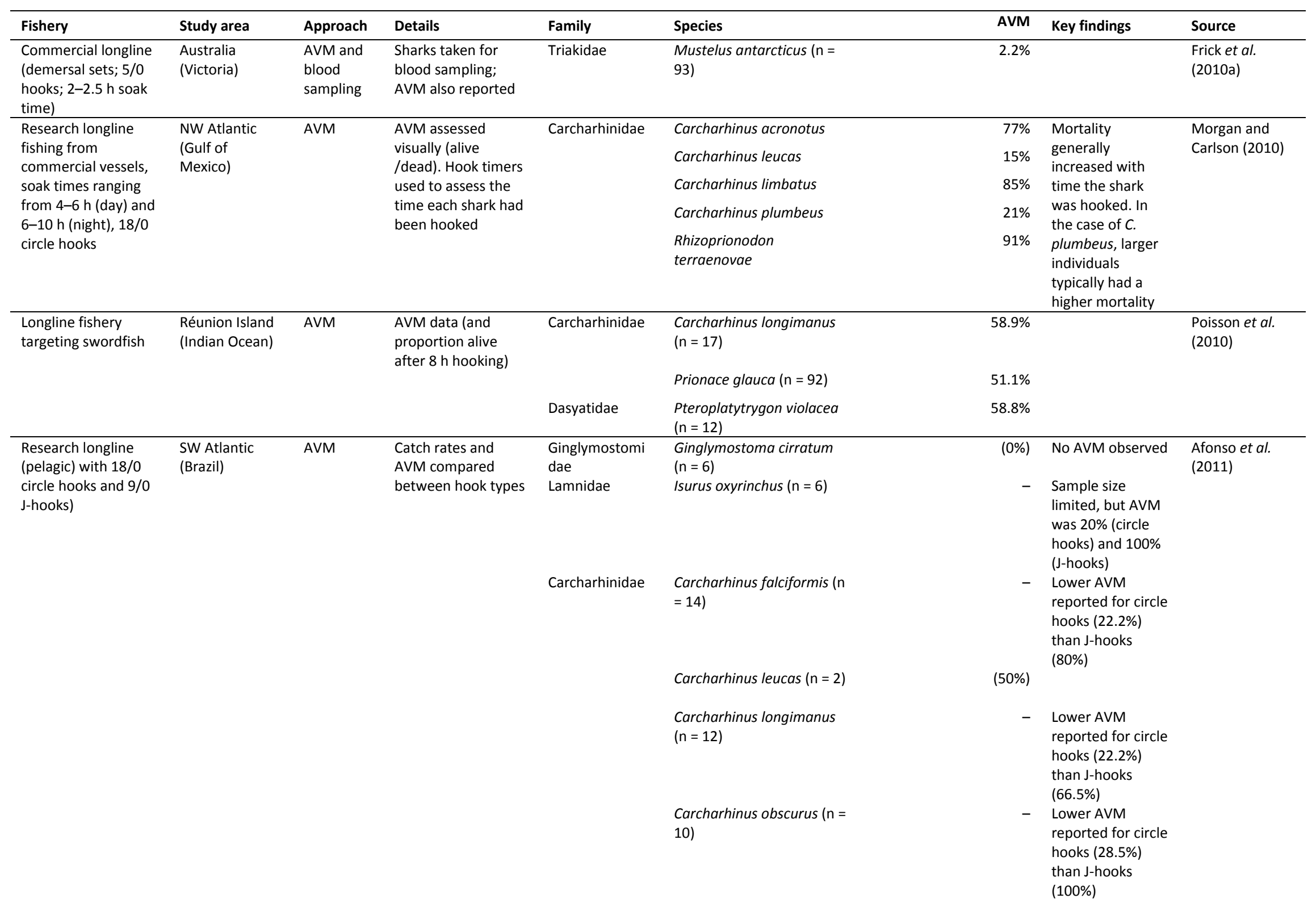




\begin{tabular}{|c|c|c|c|c|c|c|c|c|}
\hline Fishery & Study area & Approach & Details & Family & Species & AVM & Key findings & Source \\
\hline & & & & & $\begin{array}{l}\text { Carcharhinus signatus }(\mathrm{n}= \\
33 \text { ) }\end{array}$ & $100 \%$ & $\begin{array}{l}\text { AVM was } 100 \% \\
\text { for both hook } \\
\text { types }\end{array}$ & \\
\hline & & & & & Galeocerdo cuvier $(n=8)$ & - & $\begin{array}{l}\text { Lower AVM } \\
\text { reported for circle } \\
\text { hooks }(16.6 \%) \\
\text { than J-hooks } \\
(50 \%)\end{array}$ & \\
\hline & & & & & Prionace glauca $(\mathrm{n}=32)$ & - & $\begin{array}{l}\text { Lower AVM } \\
\text { reported for circle } \\
\text { hooks (27.2\%) } \\
\text { than J-hooks } \\
(70 \%)\end{array}$ & \\
\hline & & & & Sphyrnidae & Sphyrna lewini $(\mathrm{n}=11)$ & - & $\begin{array}{l}\text { Lower AVM } \\
\text { reported for circle } \\
\text { hooks }(33.3 \%) \\
\text { than J-hooks } \\
(87.5 \%)\end{array}$ & \\
\hline \multirow{3}{*}{$\begin{array}{l}\text { Research longline } \\
\text { (demersal and mid- } \\
\text { water) with } 18 / 0 \\
\text { circle hooks and } 9 / 0 \\
\text { J-hooks) }\end{array}$} & \multirow[t]{3}{*}{$\begin{array}{l}\text { SW Atlantic } \\
\text { (Brazil) }\end{array}$} & \multirow[t]{3}{*}{ AVM } & \multirow{3}{*}{$\begin{array}{l}\text { Catch rates } \\
\text { compared for } \\
\text { demersal and mid- } \\
\text { water hooks; AVM } \\
\text { compared between } \\
\text { hook types. Limited } \\
\text { data also available } \\
\text { for five other } \\
\text { elasmobranch } \\
\text { species }\end{array}$} & $\begin{array}{l}\text { Ginglymostomi } \\
\text { dae }\end{array}$ & $\begin{array}{l}\text { Ginglymostoma cirratum } \\
(\mathrm{n}=14)\end{array}$ & $0 \%$ & No AVM observed & $\begin{array}{l}\text { Afonso et al. } \\
\text { (2011) }\end{array}$ \\
\hline & & & & & & & to $74 \%$ (J-hooks) & \\
\hline & & & & Dasyatidae & $\begin{array}{l}\text { Dasyatis americana }(\mathrm{n}= \\
43)\end{array}$ & $0 \%$ & No AVM observed & \\
\hline \multirow[t]{3}{*}{$\begin{array}{l}\text { Commercial } \\
\text { longliners targeting } \\
\text { swordfish }\end{array}$} & \multirow[t]{3}{*}{$\begin{array}{l}\text { Atlantic and } \\
\text { Indian Oceans }\end{array}$} & \multirow[t]{3}{*}{ AVM } & \multirow[t]{3}{*}{ AVM recorded } & Alopiidae & Alopias superciliosus & $48.6-68.4 \%$ & $\begin{array}{l}\text { AVM ranged from } \\
48.6 \% \text { ( } n=849 ; \\
\text { Atlantic) to } 68.4 \% \\
\text { ( } n=19 ; \text { Indian } \\
\text { Ocean) }\end{array}$ & $\begin{array}{l}\text { Coelho et al. } \\
\text { (2011) }\end{array}$ \\
\hline & & & & Lamnidae & Isurus oxyrinchus & $32.8-56.0 \%$ & $\begin{array}{l}\text { AVM ranged from } \\
32.8 \% \text { ( } n=1,004 ; \\
\text { Atlantic) to } 56.0 \% \\
\text { ( } n=430 ; \text { Indian } \\
\text { Ocean) }\end{array}$ & \\
\hline & & & & Carcharhinidae & Carcharhinus falciformis & $55.1-74.2 \%$ & $\begin{array}{l}\text { AVM ranged from } \\
55.1 \% \text { ( }=296 ; \\
\text { Atlantic) to } 74.2 \% \\
\text { ( } n=31 ; \text { Indian } \\
\text { Ocean) }\end{array}$ & \\
\hline
\end{tabular}




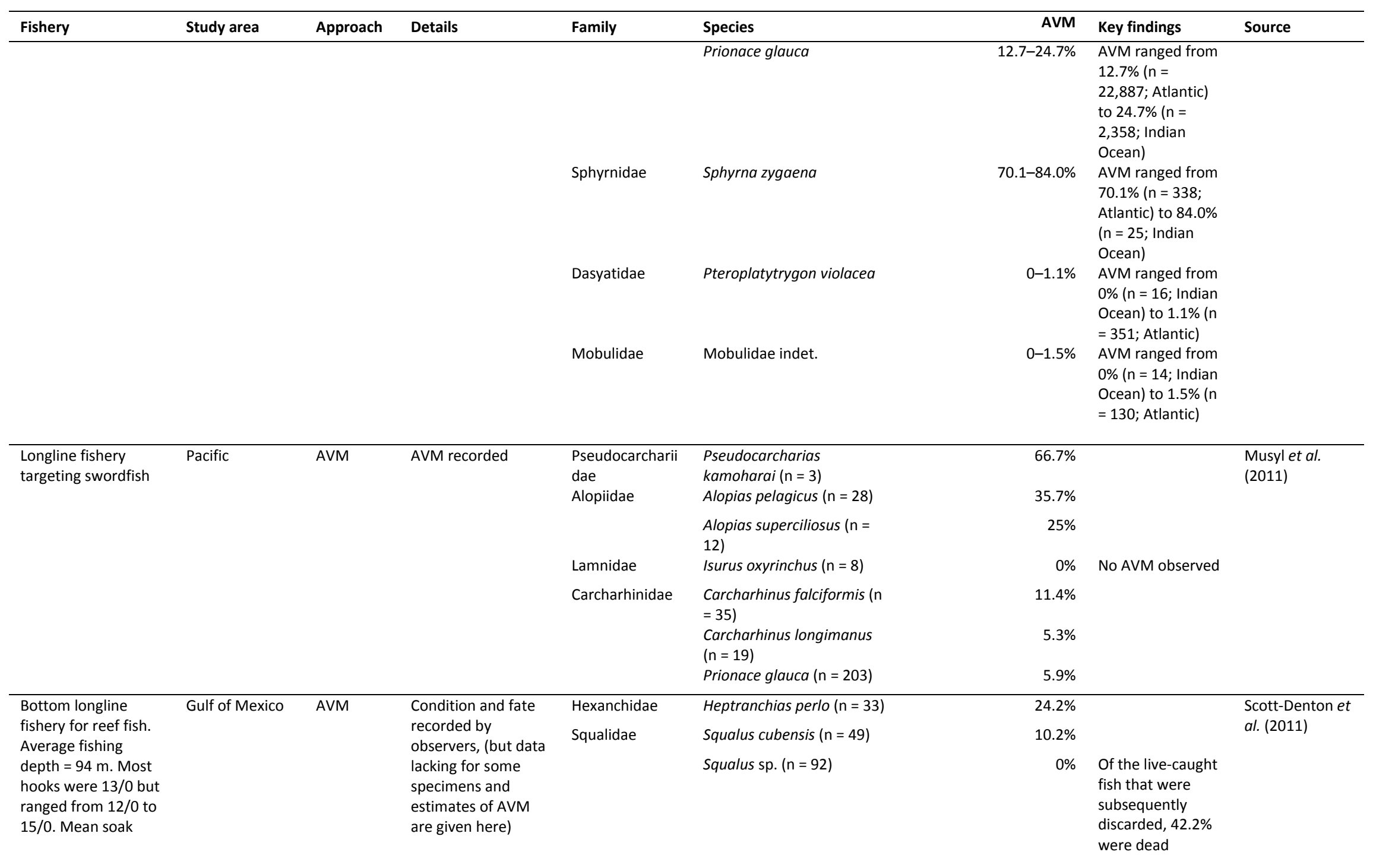




\begin{tabular}{|c|c|c|c|c|c|c|c|c|}
\hline Fishery & Study area & Approach & Details & Family & Species & AVM & Key findings & Source \\
\hline \multirow[t]{16}{*}{$\begin{array}{l}\text { time was } 5.1 \mathrm{~h} \\
\text { (range }=0.9-32.2 \mathrm{~h} \text { ) }\end{array}$} & & & & Centrophoridae & $\begin{array}{l}\text { Centrophorus granulosus } \\
(n=35)\end{array}$ & $0 \%$ & $\begin{array}{l}\text { Of the live-caught } \\
\text { fish that were } \\
\text { subsequently } \\
\text { discarded, } 14.3 \% \\
\text { were dead }\end{array}$ & \\
\hline & & & & $\begin{array}{l}\text { Ginglymostomi } \\
\text { dae }\end{array}$ & $\begin{array}{l}\text { Ginglymostoma cirratum } \\
(n=163)\end{array}$ & NA & $\begin{array}{l}\text { AVM not } \\
\text { estimated, but } \\
87.1 \% \text { released } \\
\text { alive }\end{array}$ & \\
\hline & & & & Triakidae & Mustelus canis $(n=1279)$ & $0.8 \%$ & & \\
\hline & & & & & Mustelus sp. $(\mathrm{n}=72)$ & $0 \%$ & $\begin{array}{l}\text { Of the live-caught } \\
\text { fish that were } \\
\text { subsequently } \\
\text { discarded, } 1.4 \% \\
\text { were dead }\end{array}$ & \\
\hline & & & & Carcharhinidae & $\begin{array}{l}\text { Carcharhinus acronotus ( } \mathrm{n} \\
=801 \text { ) }\end{array}$ & $8.0 \%$ & & \\
\hline & & & & & $\begin{array}{l}\text { Carcharhinus brevipinna ( } \mathrm{n} \\
=26 \text { ) }\end{array}$ & $3.8 \%$ & $\begin{array}{l}\text { Of the live-caught } \\
\text { fish that were } \\
\text { subsequently } \\
\text { discarded, } 34.8 \% \\
\text { were dead }\end{array}$ & \\
\hline & & & & & $\begin{array}{l}\text { Carcharhinus falciformis ( } \mathrm{n} \\
=94 \text { ) }\end{array}$ & $26.6 \%$ & & \\
\hline & & & & & $\begin{array}{l}\text { Carcharhinus leucas }(n= \\
43 \text { ) }\end{array}$ & $2.3 \%$ & & \\
\hline & & & & & $\begin{array}{l}\text { Carcharhinus limbatus ( } \mathrm{n}= \\
87 \text { ) }\end{array}$ & $23.0 \%$ & & \\
\hline & & & & & $\begin{array}{l}\text { Carcharhinus plumbeus ( } \mathrm{n} \\
=59 \text { ) }\end{array}$ & $3.4 \%$ & & \\
\hline & & & & & $\begin{array}{l}\text { Carcharhinus porosus }(\mathrm{n}= \\
48 \text { ) }\end{array}$ & $0 \%$ & & \\
\hline & & & & & $\begin{array}{l}\text { Galeocerdo cuvier }(\mathrm{n}= \\
102)\end{array}$ & $0.9 \%$ & & \\
\hline & & & & & $\begin{array}{l}\text { Negaprion brevirostris }(\mathrm{n}= \\
157)\end{array}$ & $1.9 \%$ & & \\
\hline & & & & & $\begin{array}{l}\text { Rhizoprionodon } \\
\text { terraenovae }(n=2090)\end{array}$ & $19.1 \%$ & & \\
\hline & & & & Sphyrnidae & Sphyrna lewini $(\mathrm{n}=73)$ & $19.2 \%$ & & \\
\hline & & & & Rajidae & $\begin{array}{l}\text { Leucoraja eglanteria }(\mathrm{n}= \\
50)\end{array}$ & $4 \%$ & & \\
\hline
\end{tabular}




\begin{tabular}{|c|c|c|c|c|c|c|c|c|}
\hline Fishery & Study area & Approach & Details & Family & Species & AVM & Key findings & Source \\
\hline $\begin{array}{l}\text { Vertical line fishery } \\
\text { for reef fish. } \\
\text { Average fishing } \\
\text { depth }=50 \mathrm{~m} . \text { Most } \\
\text { hooks were } 8 / 0 \text { or } \\
9 / 0 . \text { Mean soak time } \\
\text { was } 0.7 \mathrm{~h} \text { (range = }\end{array}$ & Gulf of Mexico & AVM & $\begin{array}{l}\text { Condition and fate } \\
\text { recorded by } \\
\text { observers, (but data } \\
\text { lacking for some } \\
\text { specimens and } \\
\text { estimates of AVM } \\
\text { are given here) }\end{array}$ & $\begin{array}{l}\text { Ginglymostomi } \\
\text { dae }\end{array}$ & $\begin{array}{l}\text { Ginglymostoma cirratum } \\
(n=33)\end{array}$ & $0 \%$ & $\begin{array}{l}\text { Whilst no AVM } \\
\text { was reported, } \\
6.1 \% \text { of the } \\
\text { specimens } \\
\text { subsequently } \\
\text { discarded were } \\
\text { dead }\end{array}$ & $\begin{array}{l}\text { Scott-Denton et } \\
\text { al. (2011) }\end{array}$ \\
\hline \multirow[t]{5}{*}{$0.02-15.3$ h) } & & & & Triakidae & Mustelus canis $(\mathrm{n}=35)$ & $0 \%$ & $\begin{array}{l}\text { Whilst no AVM } \\
\text { was reported, } \\
12.5 \% \text { of the } \\
\text { specimens } \\
\text { subsequently } \\
\text { discarded were } \\
\text { dead }\end{array}$ & \\
\hline & & & & Carcharhinidae & $\begin{array}{l}\text { Carcharhinus acronotus ( } \mathrm{n} \\
=32 \text { ) }\end{array}$ & $3.1 \%$ & $\begin{array}{l}\text { Of those } \\
\text { specimens caught } \\
\text { alive, } 12.9 \% \text { were } \\
\text { subsequently } \\
\text { discarded dead }\end{array}$ & \\
\hline & & & & & $\begin{array}{l}\text { Carcharhinus falciformis ( } \mathrm{n} \\
=71 \text { ) }\end{array}$ & $0 \%$ & $\begin{array}{l}\text { Whilst no AVM } \\
\text { was reported, } \\
1.4 \% \text { of the } \\
\text { specimens } \\
\text { subsequently } \\
\text { discarded were } \\
\text { dead }\end{array}$ & \\
\hline & & & & & $\begin{array}{l}\text { Carcharhinus limbatus }(\mathrm{n}= \\
\text { 39) }\end{array}$ & $0 \%$ & $\begin{array}{l}\text { Whilst no AVM } \\
\text { was reported, } \\
15.8 \% \text { of the } \\
\text { specimens } \\
\text { subsequently } \\
\text { discarded were } \\
\text { dead }\end{array}$ & \\
\hline & & & & & $\begin{array}{l}\text { Rhizoprionodon } \\
\text { terraenovae }(n=83)\end{array}$ & $0 \%$ & $\begin{array}{l}\text { Whilst no AVM } \\
\text { was reported, } \\
7.6 \% \text { of the } \\
\text { specimens } \\
\text { subsequently } \\
\text { discarded were } \\
\text { dead }\end{array}$ & \\
\hline $\begin{array}{l}\text { Research fishing } \\
\text { from a commercial } \\
\text { longline vessel }\end{array}$ & $\begin{array}{l}\text { SW Atlantic } \\
\text { (Brazil) }\end{array}$ & AVM & $\begin{array}{l}\text { AVM recorded; } \\
\text { catch rates and } \\
\text { 'bite-offs' recorded }\end{array}$ & $\begin{array}{l}\text { Pseudocarcharii } \\
\text { dae } \\
\text { Alopiidae }\end{array}$ & $\begin{array}{l}\text { Pseudocarcharias } \\
\text { kamoharai }(\mathrm{n}=11) \\
\text { Alopias spp. }(\mathrm{n}=9)\end{array}$ & $\begin{array}{l}91 \% \\
89 \%\end{array}$ & & $\begin{array}{l}\text { Afonso et al. } \\
\text { (2012) }\end{array}$ \\
\hline
\end{tabular}




\begin{tabular}{|c|c|c|c|c|c|c|c|c|}
\hline Fishery & Study area & Approach & Details & Family & Species & AVM & Key findings & Source \\
\hline \multirow{6}{*}{$\begin{array}{l}\text { (pelagic), with } \\
\text { combinations of wire } \\
\text { and monofilament } \\
\text { leaders, and circle } \\
\text { and J-hooks }\end{array}$} & & & & Lamnidae & Isurus spp. $(\mathrm{n}=4)$ & $75 \%$ & & \\
\hline & & & & Carcharhinidae & $\begin{array}{l}\text { Carcharhinus falciformis ( } \mathrm{n} \\
=24 \text { ) }\end{array}$ & $75 \%$ & & \\
\hline & & & & & $\begin{array}{l}\text { Carcharhinus longimanus } \\
(\mathrm{n}=11)\end{array}$ & $82 \%$ & & \\
\hline & & & & & Galeocerdo cuvier $(\mathrm{n}=3)$ & $(67 \%)$ & & \\
\hline & & & & & Prionace glauca $(\mathrm{n}=77)$ & $31 \%$ & & \\
\hline & & & & Sphyrnidae & Sphyrna spp. $(\mathrm{n}=3)$ & $100 \%$ & & \\
\hline \multirow[t]{15}{*}{$\begin{array}{l}\text { Commercial longline } \\
\text { fishery }\end{array}$} & Pacific & AVM & $\begin{array}{l}\text { AVM recorded from } \\
\text { observer coverage }\end{array}$ & $\begin{array}{l}\text { Pseudocarcharii } \\
\text { dae }\end{array}$ & $\begin{array}{l}\text { Pseudocarcharias } \\
\text { kamoharai }(\mathrm{n}=139)\end{array}$ & $38.7 \%$ & & $\begin{array}{l}\text { Bromhead et al. } \\
\text { (2012) }\end{array}$ \\
\hline & & & & Alopiidae & $\begin{array}{l}\text { Alopias pelagicus }(\mathrm{n}= \\
1353)\end{array}$ & $63.8 \%$ & & \\
\hline & & & & & $\begin{array}{l}\text { Alopias superciliosus }(\mathrm{n}= \\
\text { 1636) }\end{array}$ & $50.0 \%$ & & \\
\hline & & & & & Alopias vulpinus $(\mathrm{n}=87)$ & $52.9 \%$ & & \\
\hline & & & & Lamnidae & Isurus oxyrinchus $(\mathrm{n}=171)$ & $50.3 \%$ & & \\
\hline & & & & Carcharhinidae & $\begin{array}{l}\text { Carcharhinus } \\
\text { albimarginatus }(n=20)\end{array}$ & $15.0 \%$ & & \\
\hline & & & & & $\begin{array}{l}\text { Carcharhinus } \\
\text { amblyrhynchos }(\mathrm{n}=4)\end{array}$ & $(50.0 \%)$ & & \\
\hline & & & & & $\begin{array}{l}\text { Carcharhinus brachyurus } \\
(n=19)\end{array}$ & $5.6 \%$ & & \\
\hline & & & & & $\begin{array}{l}\text { Carcharhinus falciformis ( } \mathrm{n} \\
=3242 \text { ) }\end{array}$ & $26.5 \%$ & & \\
\hline & & & & & $\begin{array}{l}\text { Carcharhinus galapagensis } \\
(n=8)\end{array}$ & $(25.0 \%)$ & & \\
\hline & & & & & $\begin{array}{l}\text { Carcharhinus limbatus }(\mathrm{n}= \\
\text { 10) }\end{array}$ & $60.0 \%$ & & \\
\hline & & & & & $\begin{array}{l}\text { Carcharhinus longimanus } \\
(\mathrm{n}=917)\end{array}$ & $30.6 \%$ & & \\
\hline & & & & & $\begin{array}{l}\text { Carcharhinus plumbeus ( } \mathrm{n} \\
=1 \text { ) }\end{array}$ & $(0 \%)$ & & \\
\hline & & & & & Galeocerdo cuvier $(n=5)$ & $(60.0 \%)$ & & \\
\hline & & & & & Prionace glauca $(\mathrm{n}=3452)$ & $19.6 \%$ & & \\
\hline
\end{tabular}




\begin{tabular}{|c|c|c|c|c|c|c|c|c|}
\hline Fishery & Study area & Approach & Details & Family & Species & AVM & Key findings & Source \\
\hline & & & & Sphyrnidae & $\begin{array}{l}\text { Sphyrna lewini }(n=5) \text { and } \\
\text { S. mokarran }(n=3)\end{array}$ & $(75 \%)$ & $\begin{array}{l}\text { Although data } \\
\text { were limited, } \\
\text { AVM was } 75 \% \text { for } \\
\text { this genus }\end{array}$ & \\
\hline & & & & Dasyatidae & $\begin{array}{l}\text { Pteroplatytrygon violacea } \\
(\mathrm{n}=501)\end{array}$ & $18.5 \%$ & & \\
\hline \multirow[t]{18}{*}{ Pelagic longline } & Atlantic & AVM & $\begin{array}{l}\text { AVM recorded by } \\
\text { observers on }\end{array}$ & $\begin{array}{l}\text { Pseudocarcharii } \\
\text { dae }\end{array}$ & $\begin{array}{l}\text { Pseudocarcharias } \\
\text { kamoharai }(\mathrm{n}=1621)\end{array}$ & $13.3 \%$ & & $\begin{array}{l}\text { Coelho et al. } \\
(2012)\end{array}$ \\
\hline & & & commercial vessels & Alopiidae & & $50.6 \%$ & & \\
\hline & & & & & Alopias vulpinus $(\mathrm{n}=3)$ & $(66.7 \%)$ & & \\
\hline & & & & Lamnidae & $\begin{array}{l}\text { Isurus oxyrinchus }(\mathrm{n}= \\
1414)\end{array}$ & $35.6 \%$ & & \\
\hline & & & & & Isurus paucus $(\mathrm{n}=168)$ & $30.7 \%$ & & \\
\hline & & & & & Lamna nasus $(\mathrm{n}=10)$ & $30.0 \%$ & & \\
\hline & & & & Triakidae & Galeorhinus galeus $(n=25)$ & $0 \%$ & & \\
\hline & & & & Carcharhinidae & $\begin{array}{l}\text { Carcharhinus altimus }(\mathrm{n}= \\
11 \text { ) }\end{array}$ & $60.0 \%$ & & \\
\hline & & & & & $\begin{array}{l}\text { Carcharhinus falciformis ( } \mathrm{n} \\
=310 \text { ) }\end{array}$ & $55.8 \%$ & & \\
\hline & & & & & $\begin{array}{l}\text { Carcharhinus longimanus } \\
(\mathrm{n}=281)\end{array}$ & $34.2 \%$ & & \\
\hline & & & & & Galeocerdo cuvier $(n=36)$ & $2.9 \%$ & & \\
\hline & & & & & $\begin{array}{l}\text { Prionace glauca }(\mathrm{n}= \\
\text { 30168) }\end{array}$ & $14.3 \%$ & & \\
\hline & & & & Sphyrnidae & Sphyrna lewini $(\mathrm{n}=21)$ & $57.1 \%$ & Whilst no AVM & \\
\hline & & & & & Sphyrna mokarran $(\mathrm{n}=3)$ & $(0 \%)$ & $\begin{array}{l}\text { was observed for } \\
\text { S. mokarran, this }\end{array}$ & \\
\hline & & & & & Sphyrna zygaena $(\mathrm{n}=372)$ & $71 \%$ & $\begin{array}{l}\text { was based on a } \\
\text { small sample size }\end{array}$ & \\
\hline & & & & Dasyatidae & $\begin{array}{l}\text { Pteroplatytrygon violacea } \\
(\mathrm{n}=396)\end{array}$ & $1.0 \%$ & & \\
\hline & & & & Mobulidae & $\begin{array}{l}\text { Data collected at family } \\
\text { level }(n=145)\end{array}$ & $1.4 \%$ & & \\
\hline & & & & Myliobatidae & $\begin{array}{l}\text { Data collected at family } \\
\text { level }(n=19)\end{array}$ & $0 \%$ & $\begin{array}{l}\text { No AVM observed } \\
\text { for this family }\end{array}$ & \\
\hline Pelagic longline & $\begin{array}{l}\text { NW Atlantic } \\
\text { (Grand Banks) }\end{array}$ & AVM & $\begin{array}{l}\text { Observers recorded } \\
\text { condition of fish } \\
\text { brought aboard }\end{array}$ & Lamnidae & Isurus oxyrinchus $(\mathrm{n}=543)$ & $21.3-26.5 \%$ & $\begin{array}{l}\text { AVM of } I . \\
\text { oxyrinchus was } \\
26.5 \%(9 / 0 \mathrm{~J}-\end{array}$ & $\begin{array}{l}\text { Epperly et al. } \\
\text { (2012) }\end{array}$ \\
\hline
\end{tabular}




\begin{tabular}{|c|c|c|c|c|c|c|c|c|}
\hline Fishery & Study area & Approach & Details & Family & Species & AVM & Key findings & Source \\
\hline & & & $\begin{array}{l}\text { commercial vessels } \\
\text { that were chartered } \\
\text { to use sets with J- } \\
\text { hooks and circle } \\
\text { hooks. AVM } \\
\text { provided based on } \\
\text { fish recorded as } \\
\text { alive or dead (fish } \\
\text { that were damaged, } \\
\text { entangled in the } \\
\text { mainline or for } \\
\text { undetermined hook } \\
\text { type were excluded) }\end{array}$ & Carcharhinidae & $\begin{array}{l}\text { Lamna nasus }(\mathrm{n}=866) \\
\text { Prionace glauca }(\mathrm{n}= \\
21,684)\end{array}$ & $\begin{array}{l}29.5-31.6 \% \\
18.8-22.6 \%\end{array}$ & $\begin{array}{l}\text { hook), falling to } \\
21.3 \% \text { and } 23.7 \% \\
\text { for } 18 / 0 \text { circle } \\
\text { hooks with no and } \\
10^{\circ} \text { offset, } \\
\text { respectively. AVM } \\
\text { of } L \text {. nasus was } \\
\text { similar (29.5- } \\
31.6 \% \text { ) for all } \\
\text { hook types. } \\
\text { AVM was } 22.6 \% \\
\text { (9/0 J-hook), } \\
\text { falling to } 19.9 \% \\
\text { and } 18.8 \% \text { for } \\
18 / 0 \text { circle hooks } \\
\text { with no and } 10^{\circ} \\
\text { offset, } \\
\text { respectively }\end{array}$ & \\
\hline Pelagic longline & NW Atlantic & AVM & $\begin{array}{l}\text { Observer data on } \\
\text { condition } \\
\text { (live/dead) used to } \\
\text { compare hooking } \\
\text { survival for periods } \\
\text { before and after the } \\
\text { introduction of } \\
\text { circle hook } \\
\text { requirements. Fish } \\
\text { that were recorded } \\
\text { as 'damaged' or of } \\
\text { 'unknown' fate } \\
\text { were excluded }\end{array}$ & Carcharhinidae & $\begin{array}{l}\text { Prionace glauca }(\mathrm{n}= \\
10,977) \\
\text { Carcharhinus falciformis ( } \mathrm{n} \\
=2,071)\end{array}$ & $44-59 \%$ & $\begin{array}{l}\text { AVM did not } \\
\text { change between } \\
\text { the two periods } \\
\text { AVM decreased } \\
\text { from } 59 \% \text { to } 44 \% \\
\text { after the } \\
\text { introduction of } \\
\text { circle hook } \\
\text { regulations }\end{array}$ & $\begin{array}{l}\text { Serafy et al. } \\
\text { (2012) }\end{array}$ \\
\hline Pelagic longline & $\begin{array}{l}\text { Tropical north- } \\
\text { east Atlantic }\end{array}$ & AVM & $\begin{array}{l}\text { Fate recorded for } \\
\text { sharks taken on } \\
\text { different hook types } \\
\text { (J, circle and offset } \\
\text { circle hooks) and } \\
\text { baits (squid and } \\
\text { mackerel }\end{array}$ & $\begin{array}{l}\text { Pseudocarcharii } \\
\text { dae }\end{array}$ & $\begin{array}{l}\text { Pseudocarcharias } \\
\text { kamoharai }(\mathrm{n}=664)\end{array}$ & $4.7-9.1 \%$ & $\begin{array}{l}\text { AVM }=4.7 \%(\mathrm{~J}- \\
\text { hooks, } n=190) \text {, } \\
8.1 \% \text { (circle } \\
\text { hooks, } n=211 \text { ) } \\
\text { and } 9.1 \% \text { (offset } \\
\text { circle hooks, } n= \\
\text { 263) }\end{array}$ & $\begin{array}{l}\text { Fernandez- } \\
\text { Carvalho et al. } \\
\text { (2015) }\end{array}$ \\
\hline
\end{tabular}




\begin{tabular}{|c|c|c|c|c|c|c|c|c|}
\hline Fishery & Study area & Approach & Details & Family & Species & AVM & Key findings & Source \\
\hline & & & & Alopiidae & $\begin{array}{l}\text { Alopias superciliosus }(\mathrm{n}= \\
815)\end{array}$ & $49.6-58.5 \%$ & $\begin{array}{l}\text { AVM }=49.6 \% \\
\text { (offset circle } \\
\text { hooks, } n=248 \text { ) } \\
\text { and } 49.8 \%(J- \\
\text { hooks, } n=295) \text {, } \\
\text { but higher with } \\
\text { circle hooks } \\
(58.5 \%, n=272)\end{array}$ & \\
\hline & & & & 更 & $\begin{array}{l}\text { Carcharhinus longimanus } \\
(\mathrm{n}=152)\end{array}$ & $11.1-28.4 \%$ & $\begin{array}{l}\text { AVM }=28.4 \% \\
\text { (offset circle } \\
\text { hooks, } n=81) \text { and } \\
22.7 \%(J-\text { hooks, } n \\
=44), \text { but lower } \\
\text { with circle hooks } \\
(11.1 \% ; n=27)\end{array}$ & \\
\hline & & & & Sphyrnidae & Sphyrna zygaena $(\mathrm{n}=203)$ & $62.0-62.9 \%$ & $\begin{array}{l}\text { AVM was higher } \\
\text { for this species } \\
\text { (62.0-62.9\% for } \\
\text { the three hook } \\
\text { types) }\end{array}$ & \\
\hline \multirow{3}{*}{$\begin{array}{l}\text { Pelagic longline } \\
\text { (targeting tuna or } \\
\text { swordfish) }\end{array}$} & \multirow[t]{3}{*}{ NW Atlantic } & \multirow[t]{3}{*}{ AVM } & \multirow{3}{*}{$\begin{array}{l}\text { AVM data collected } \\
\text { by observers (1995- } \\
\text { 2012). Data used for } \\
\text { fish classed as alive } \\
\text { and dead (those } \\
\text { reported as }\end{array}$} & & $\begin{array}{l}\text { Alopias superciliosus }(\mathrm{n}= \\
367)\end{array}$ & $51.7 \%$ & & \multirow[t]{3}{*}{$\begin{array}{l}\text { Gallagher et al. } \\
\text { (2014a) }\end{array}$} \\
\hline & & & & Lamnidae & $\begin{array}{l}\text { Isurus oxyrinchus }(\mathrm{n}= \\
2126)\end{array}$ & $28.6 \%$ & & \\
\hline & & & & & Isurus paucus $(\mathrm{n}=139)$ & $51.1 \%$ & & \\
\hline
\end{tabular}




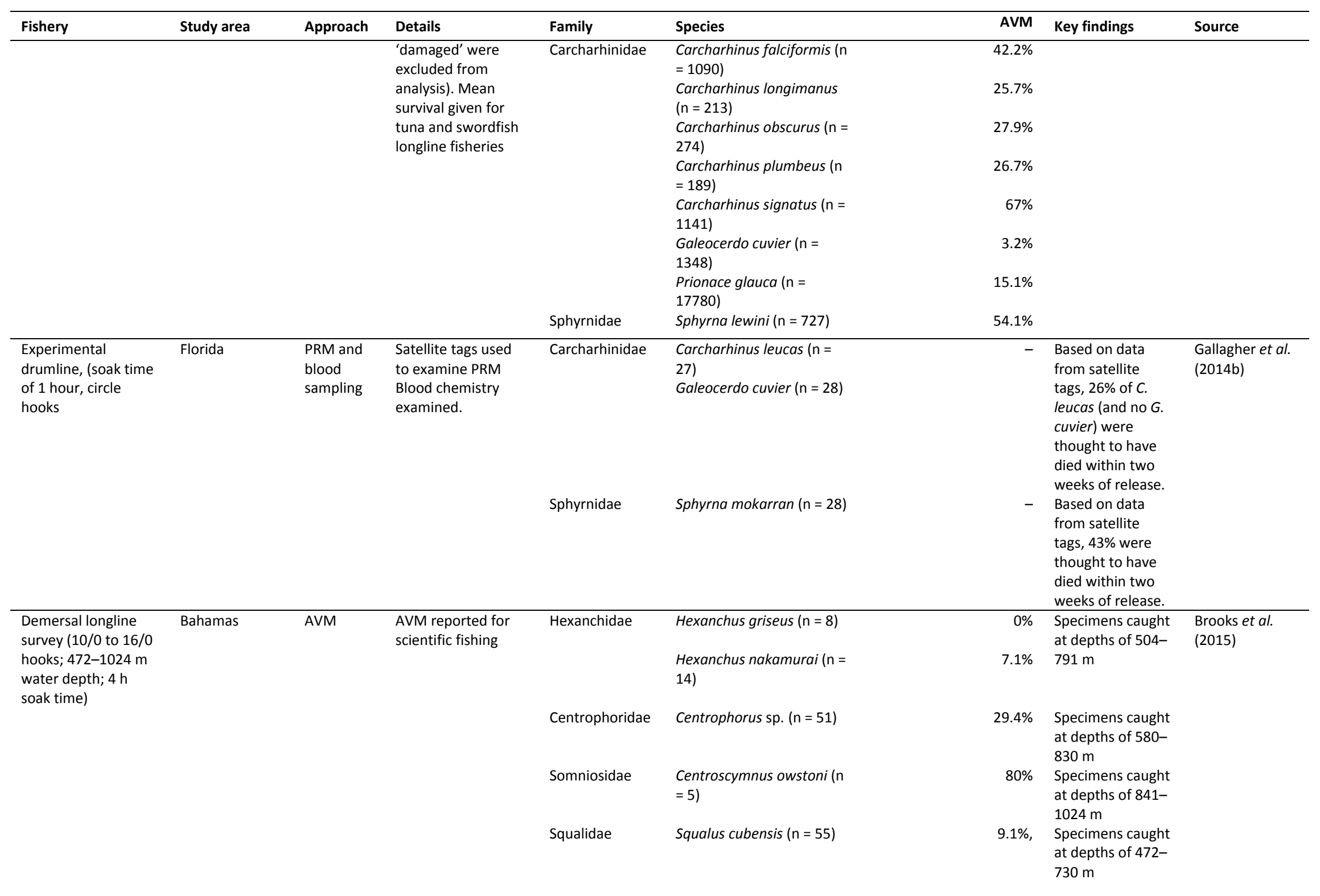




\begin{tabular}{|c|c|c|c|c|c|c|c|c|}
\hline Fishery & Study area & Approach & Details & Family & Species & AVM & Key findings & Source \\
\hline & & & & Scyliorhinidae & Galeus springeri $(\mathrm{n}=3)$ & $66.7 \%$ & $\begin{array}{l}\text { Specimens caught } \\
\text { at depths of } 630- \\
807 \mathrm{~m}\end{array}$ & \\
\hline & & & & Pseudotriakidae & $\begin{array}{l}\text { Pseudotriakis microdon ( } \mathrm{n} \\
=1 \text { ) }\end{array}$ & - & $\begin{array}{l}\text { No AVM, but } \\
\text { based on a single } \\
\text { specimen caught } \\
\text { at } 790 \mathrm{~m} \text { depth }\end{array}$ & \\
\hline & & & & Triakidae & Mustelus canis $(n=7)$ & $0 \%$ & $\begin{array}{l}\text { Specimens caught } \\
\text { at depths of 504- } \\
651 \mathrm{~m}\end{array}$ & \\
\hline \multirow{16}{*}{$\begin{array}{l}\text { Demersal longline } \\
\text { with nylon trace and } \\
16 / 0 \text { non-offset } \\
\text { circle hook (water } \\
\text { depths } 50-100 \mathrm{~m} ; 7- \\
14 \text { h soak times; } \\
\text { hook timers used) }\end{array}$} & \multirow{16}{*}{$\begin{array}{l}\text { New South } \\
\text { Wales } \\
\text { (Australia) }\end{array}$} & \multirow{16}{*}{$\begin{array}{l}\text { AVM and } \\
\text { blood } \\
\text { sampling }\end{array}$} & \multirow{16}{*}{$\begin{array}{l}\text { Survival and } \\
\text { condition examined } \\
\text { in relation to } \\
\text { hooking time. Blood } \\
\text { samples also } \\
\text { collected. }\end{array}$} & \multirow[t]{3}{*}{ Orectolobidae } & Orectolobus halei $(\mathrm{n}=3)$ & $0 \%$ & \multirow{3}{*}{$\begin{array}{l}\text { No AVM for soak } \\
\text { times up to } 14 \mathrm{~h}\end{array}$} & \multirow{16}{*}{$\begin{array}{l}\text { Butcher et al. } \\
\text { (2015) }\end{array}$} \\
\hline & & & & & $\begin{array}{l}\text { Orectolobus maculatus ( } \mathrm{n} \\
=10 \text { ) }\end{array}$ & $0 \%$ & & \\
\hline & & & & & $\begin{array}{l}\text { Orectolobus ornatus ( } \mathrm{n}= \\
5 \text { ) }\end{array}$ & $0 \%$ & & \\
\hline & & & & Odontaspididae & Carcharias taurus $(\mathrm{n}=12)$ & $0 \%$ & $\begin{array}{l}\text { No AVM for soak } \\
\text { times up to } 14 \mathrm{~h}\end{array}$ & \\
\hline & & & & Triakidae & $\begin{array}{l}\text { Mustelus antarcticus ( } \mathrm{n}= \\
22 \text { ) }\end{array}$ & $20-25 \%$ & $\begin{array}{l}\text { AVM for soak } \\
\text { times up to } 14 \mathrm{~h}\end{array}$ & \\
\hline & & & & & $\begin{array}{l}\text { Carcharhinus brevipinna ( } \mathrm{n} \\
=50 \text { ) }\end{array}$ & $94.4-96.9 \%$ & \multirow{6}{*}{$\begin{array}{l}\text { Higher estimates } \\
\text { of AVM for } 14 \mathrm{~h} \\
\text { soak times, lower } \\
\text { estimates for } 7 \mathrm{~h} \\
\text { soak times }\end{array}$} & \\
\hline & & & & & Carcharhinus leucas $(n=1)$ & $(0 \%)$ & & \\
\hline & & & & & $\begin{array}{l}\text { Carcharhinus limbatus }(\mathrm{n}= \\
113)\end{array}$ & $86-95.5 \%$ & & \\
\hline & & & & & $\begin{array}{l}\text { Carcharhinus obscurus }(n= \\
\text { 74) }\end{array}$ & $53.3-79.5 \%$ & & \\
\hline & & & & & $\begin{array}{l}\text { Carcharhinus plumbeus ( } \mathrm{n} \\
=160 \text { ) }\end{array}$ & $43-62.7 \%$ & & \\
\hline & & & & & $\begin{array}{l}\text { Galeocerdo cuvier }(\mathrm{n}= \\
123)\end{array}$ & $4.3-6.6 \%$ & & \\
\hline & & & & \multirow[t]{3}{*}{ Sphyrnidae } & Sphyrna lewini $(n=52)$ & $87.5-90.1 \%$ & \multirow{3}{*}{$\begin{array}{l}\text { Higher AVM with } \\
\text { longer soak time }\end{array}$} & \\
\hline & & & & & Sphyrna. zygaena $(\mathrm{n}=2)$ & $(100 \%)$ & & \\
\hline & & & & & Sphyrna mokarran $(n=11)$ & $100 \%$ & & \\
\hline & & & & Rhinidae & $\begin{array}{l}\text { Rhynchobatus australiae } \\
(\mathrm{n}=8)\end{array}$ & $0-25 \%$ & $\begin{array}{l}\text { AVM increased } \\
\text { from } 0 \%(7 \mathrm{~h}) \text { to } \\
25 \%(14 \mathrm{~h})\end{array}$ & \\
\hline & & & & Rhinobatidae & $\begin{array}{l}\text { Aptychotrema rostrata ( } \mathrm{n} \\
=2 \text { ) }\end{array}$ & $(0 \%)$ & No AVM recorded & \\
\hline
\end{tabular}




\begin{tabular}{|c|c|c|c|c|c|c|c|c|}
\hline Fishery & Study area & Approach & Details & Family & Species & AVM & Key findings & Source \\
\hline & & & & Dasyatidae & $\begin{array}{l}\text { Dasyatis brevicaudata }(\mathrm{n}= \\
\text { 18) }\end{array}$ & $0 \%$ & No AVM recorded & \\
\hline \multirow[t]{18}{*}{$\begin{array}{l}\text { Pelagic longline } \\
\text { fishery for tuna }\end{array}$} & Palau (Pacific) & AVM & $\begin{array}{l}\text { AVM data collected } \\
\text { by observers }\end{array}$ & Squatinidae & $\begin{array}{l}\text { Squatina tergocellatoides } \\
(n=1)\end{array}$ & $(0 \%)$ & $\begin{array}{l}\text { Sample size } \\
\text { limited }\end{array}$ & $\begin{array}{l}\text { Gilman et al. } \\
\text { (2015) }\end{array}$ \\
\hline & & & & $\begin{array}{l}\text { Pseudocarcharii } \\
\text { dae }\end{array}$ & $\begin{array}{l}\text { Pseudocarcharias } \\
\text { kamoharai }(\mathrm{n}=2)\end{array}$ & $(0 \%)$ & $\begin{array}{l}\text { Sample size } \\
\text { limited }\end{array}$ & \\
\hline & & & & Alopiidae & $\begin{array}{l}\text { Alopias superciliosus }(\mathrm{n}= \\
41 \text { ) }\end{array}$ & $34.2 \%$ & & \\
\hline & & & & & Alopias vulpinus $(\mathrm{n}=16)$ & $18.75 \%$ & & \\
\hline & & & & Lamnidae & Isurus oxyrinchus $(\mathrm{n}=19)$ & $5.3 \%$ & & \\
\hline & & & & & Isurus paucus $(\mathrm{n}=10)$ & $40.0 \%$ & & \\
\hline & & & & Carcharhinidae & $\begin{array}{l}\text { Carcharhinus altimus }(\mathrm{n}= \\
\text { 2) }\end{array}$ & $(0 \%)$ & $\begin{array}{l}\text { Data available for } \\
\text { nine carcharhinid }\end{array}$ & \\
\hline & & & & & $\begin{array}{l}\text { Carcharhinus brachyurus } \\
(\mathrm{n}=10)\end{array}$ & $0 \%$ & & \\
\hline & & & & & $\begin{array}{l}\text { Carcharhinus falciformis ( } \mathrm{n} \\
=368 \text { ) }\end{array}$ & $29.1 \%$ & species & \\
\hline & & & & & $\begin{array}{l}\text { Carcharhinus galapagensis } \\
(n=1)\end{array}$ & $(0 \%)$ & & \\
\hline & & & & & $\begin{array}{l}\text { Carcharhinus longimanus } \\
(n=4)\end{array}$ & $(0 \%)$ & & \\
\hline & & & & & $\begin{array}{l}\text { Carcharhinus } \\
\text { melanopterus }(\mathrm{n}=5)\end{array}$ & $(0 \%)$ & & \\
\hline & & & & & $\begin{array}{l}\text { Carcharhinus plumbeus ( } \mathrm{n} \\
=6 \text { ) }\end{array}$ & $(50 \%)$ & & \\
\hline & & & & & $\begin{array}{l}\text { Galeocerdo cuvier } \quad(n= \\
\text { 8) }\end{array}$ & $(0 \%)$ & & \\
\hline & & & & & Prionace glauca $(\mathrm{n}=215)$ & $15.35 \%$ & & \\
\hline & & & & Sphyrnidae & $\begin{array}{l}\text { Sphyrna mokarran }(n=1) \\
\text { and S. lewini }(n=1)\end{array}$ & $(100 \%)$ & $\begin{array}{l}\text { Data limited, but } \\
\text { AVM }=100 \%\end{array}$ & \\
\hline & & & & Dasyatidae & $\begin{array}{l}\text { Pteroplatytrygon violacea } \\
(\mathrm{n}=372)\end{array}$ & $29.1 \%$ & & \\
\hline & & & & Mobulidae & Mobula japanica $(n=1)$ & $(0 \%)$ & $\begin{array}{l}\text { Data limited, but } \\
\text { no AVM recorded }\end{array}$ & \\
\hline \multirow{3}{*}{$\begin{array}{l}\text { Bottom longlines } \\
\text { deployed from } \\
\text { chartered fishing } \\
\text { vessels (soak times } \\
\text { of } 1.5-22.6 \mathrm{~h} ; 16 / 0 \text {, } \\
18 / 0,20 / 0 \text { circle }\end{array}$} & $\begin{array}{l}\text { NE Atlantic and } \\
\text { Gulf of Mexico } \\
\text { (North Carolina }\end{array}$ & AVM & $\begin{array}{l}\text { AVM data recorded; } \\
\text { hook timers } \\
\text { deployed }\end{array}$ & $\begin{array}{l}\text { Ginglymostomi } \\
\text { dae }\end{array}$ & $\begin{array}{l}\text { Ginglymostoma cirratum } \\
(\mathrm{n}=311)\end{array}$ & $0.3 \%$ & & $\begin{array}{l}\text { Gulak et al. } \\
\text { (2015) }\end{array}$ \\
\hline & to Louisiana) & & & Odontaspididae & Carcharias taurus $(n=13)$ & $0.0 \%$ & & \\
\hline & & & & Carcharhinidae & $\begin{array}{l}\text { Carcharhinus acronotus ( } \mathrm{n} \\
=110 \text { ) }\end{array}$ & $66.4 \%$ & & \\
\hline
\end{tabular}




\begin{tabular}{|c|c|c|c|c|c|c|c|c|}
\hline Fishery & Study area & Approach & Details & Family & Species & AVM & Key findings & Source \\
\hline \multirow[t]{10}{*}{$\begin{array}{l}\text { hooks and } 12 / 0 \mathrm{~J} \\
\text { hooks) }\end{array}$} & & & & & $\begin{array}{l}\text { Carcharhinus brevipinna ( } \mathrm{n} \\
=32 \text { ) }\end{array}$ & $81.3 \%$ & & \\
\hline & & & & & $\begin{array}{l}\text { Carcharhinus falciformis ( } \mathrm{n} \\
=35 \text { ) }\end{array}$ & $57.1 \%$ & & \\
\hline & & & & & $\begin{array}{l}\text { Carcharhinus limbatus ( } \mathrm{n}= \\
902 \text { ) }\end{array}$ & $70.8 \%$ & & \\
\hline & & & & & $\begin{array}{l}\text { Carcharhinus obscurus }(\mathrm{n}= \\
104 \text { ) }\end{array}$ & $70.2 \%$ & & \\
\hline & & & & & $\begin{array}{l}\text { Carcharhinus plumbeus ( } \\
=933 \text { ) }\end{array}$ & $16.9 \%$ & & \\
\hline & & & & & $\begin{array}{l}\text { Galeocerdo cuvier }(\mathrm{n}= \\
270)\end{array}$ & $8.9 \%$ & & \\
\hline & & & & & $\begin{array}{l}\text { Negaprion brevirostris }(\mathrm{n}= \\
\text { 24) }\end{array}$ & $4.2 \%$ & & \\
\hline & & & & & $\begin{array}{l}\text { Rhizoprionodon } \\
\text { terraenovae }(\mathrm{n}=902)\end{array}$ & $89.4 \%$ & & \\
\hline & & & & Sphyrnidae & Sphyrna lewini $(n=175)$ & $62.9 \%$ & & \\
\hline & & & & & Sphyrna mokarran $(n=75)$ & $56 \%$ & & \\
\hline $\begin{array}{l}\text { Demersal longline } \\
\text { deployed from } \\
\text { research vessel }(18 / 0 \\
\text { circle hooks with } 10^{\circ} \\
\text { offset; soak times of } \\
0.5-12.5 \mathrm{~h})\end{array}$ & & & & & $\begin{array}{l}\text { Carcharhinus plumbeus ( } \mathrm{n} \\
=119 \text { ) }\end{array}$ & $5 \%$ & $\begin{array}{l}\text { A further } 2 \% \text { of } \\
\text { specimens were } \\
\text { moribund. PRM } \\
\text { estimated at } 20 \% \\
\text { from PSAT data ( } \mathrm{n} \\
=10 \text { ) }\end{array}$ & \\
\hline $\begin{array}{l}\text { Pelagic longline } \\
\text { fishery targeting } \\
\text { tuna, swordfish and } \\
\text { blue shark }\end{array}$ & $\begin{array}{l}\text { Uruguay } \\
\text { (SW Atlantic) }\end{array}$ & AVM & & Mobulidae & $\begin{array}{l}\text { Mobulidae ( } \mathrm{n}=191 \text { with } \\
\text { fate information, } 10 \text { lost } \\
\text { during hauling) }\end{array}$ & $5.2 \%$ & $\begin{array}{l}\text { Of those } \\
\text { specimens } \\
\text { identified to } \\
\text { species, most } \\
\text { were Mobula } \\
\text { japanica or M. } \\
\text { thurstoni } \\
\end{array}$ & $\begin{array}{l}\text { Mas et al. } \\
\text { (2015) }\end{array}$ \\
\hline
\end{tabular}




\begin{tabular}{|c|c|c|c|c|c|c|c|c|}
\hline Fishery & Study area & Approach & Details & Family & Species & AVM & Key findings & Source \\
\hline \multirow[t]{3}{*}{$\begin{array}{l}\text { Commercial pelagic } \\
\text { longline targeting } \\
\text { swordfish and tuna }\end{array}$} & NW Atlantic & $\begin{array}{l}\text { AVM and } \\
\text { PRM }\end{array}$ & $\begin{array}{l}\text { Fish condition } \\
\text { (healthy, injured, } \\
\text { dead, unknown) } \\
\text { scored at } \\
\text { unhooking; PRM } \\
\text { studied using pop- } \\
\text { up satellite archival } \\
\text { tags }\end{array}$ & Lamnidae & $\begin{array}{l}\text { Isurus oxyrinchus ( } \mathrm{n}=520 \\
\text { (vitality) and } \mathrm{n}=26 \\
\text { (PSATs)) }\end{array}$ & $26.2 \%$ & $\begin{array}{l}\text { Specimens of } 80- \\
229 L_{F} \text {. Whilst } \\
\text { AVM }=26.2 \% \text {, a } \\
\text { further } 22.5 \% \\
\text { were injured. } \\
\text { PRM (healthy fish; } \\
n=23 \text { ) =30.4\% } \\
\text { PRM (injured fish; } \\
n=3)=33.3 \%\end{array}$ & $\begin{array}{l}\text { Campana et al. } \\
\text { (2016) }\end{array}$ \\
\hline & & & & & $\begin{array}{l}\text { Lamna nasus ( } \mathrm{n}=683 \\
\text { (vitality) and } \mathrm{n}=33 \\
\text { (PSATs)) }\end{array}$ & $43.8 \%$ & $\begin{array}{l}\text { Specimens of } \\
101-249 \text { LF. } \\
\text { Whilst AVM }= \\
43.8 \% \text {, a further } \\
14.6 \% \text { were } \\
\text { injured. } \\
\text { PRM (healthy fish; } \\
n=29)=10.3 \% \\
\text { PRM (injured fish; } \\
n=4)=75 \%\end{array}$ & \\
\hline & & & & Carcharhinidae & $\begin{array}{l}\text { Prionace glauca }(\mathrm{n}= \\
15,592 \text { (vitality) and } \mathrm{n}=37 \\
\text { (PSATs)) }\end{array}$ & $14.7 \%$ & $\begin{array}{l}\text { Specimens of } \\
125-209 \mathrm{LF} . \\
\text { Whilst AVM = } \\
14.7 \% \text {, a further } \\
25.1 \% \text { were } \\
\text { injured. PRM } \\
\text { (healthy fish; } \mathrm{n}= \\
10)=0 \% \\
\text { PRM (injured fish; } \\
\mathrm{n}=27 \text { ) }=33.3 \%\end{array}$ & \\
\hline \multicolumn{9}{|c|}{ PURSE SEINE FISHERIES } \\
\hline $\begin{array}{l}\text { Commercial purse } \\
\text { seine targeting gulf } \\
\text { menhaden } \\
\text { Brevoortia patronus }\end{array}$ & $\begin{array}{l}\text { NW Atlantic } \\
\text { (Gulf of } \\
\text { Mexico) }\end{array}$ & Vitality & $\begin{array}{l}\text { Observers recorded } \\
\text { fate of sharks } \\
\text { (caught and } \\
\text { released; caught } \\
\text { and retained; gilled; } \\
\text { kept by crew; } \\
\text { released but } \\
\text { disorientated; } \\
\text { released in a } \\
\text { healthy state; } \\
\text { discarded dead) }\end{array}$ & $\begin{array}{l}\text { Carcharhinidae } \\
\text { and Sphyrnidae }\end{array}$ & $\begin{array}{l}\text { Not all identified to } \\
\text { species-level. Main species } \\
\text { encountered were } \\
\text { Carcharhinus limbatus, } C \text {. } \\
\text { brevipinna, C. obscurus, C. } \\
\text { leucas, C. falciformis, C. } \\
\text { plumbeus, C. isodon, C. } \\
\text { acronotus and } \\
\text { Rhizoprionodon } \\
\text { terraenovae } \\
\text { (Carcharhinidae). A small } \\
\text { number of Sphyrna tiburo } \\
\text { also caught }\end{array}$ & - & $\begin{array}{l}\text { Most fish were } \\
\text { dead and either } \\
\text { discarded (50\%) } \\
\text { or retained on } \\
\text { board ( } 24 \%) . \\
\text { Some live fish } \\
\text { were released in } \\
\text { either a } \\
\text { disorientated } \\
(12 \%) \text { or healthy } \\
\text { (8\%) condition. } \\
\text { Fate of } 6 \% \\
\text { unknown. } \\
\end{array}$ & $\begin{array}{l}\text { De Silva et al. } \\
\text { (2001) }\end{array}$ \\
\hline
\end{tabular}




\begin{tabular}{|c|c|c|c|c|c|c|c|c|}
\hline Fishery & Study area & Approach & Details & Family & Species & AVM & Key findings & Source \\
\hline $\begin{array}{l}\text { Tuna purse seine } \\
\text { fishery }\end{array}$ & $\begin{array}{l}\text { Western } \\
\text { Central Indian } \\
\text { Ocean and } \\
\text { eastern central } \\
\text { Atlantic Ocean }\end{array}$ & AVM & $\begin{array}{l}\text { Analyses of } \\
\text { observer data } \\
\text { (where fate } \\
\text { recorded) }\end{array}$ & Rhincodontidae & Rhincodon typus & $0.9-2.6 \%$ & $\begin{array}{l}\text { Single instances of } \\
\text { mortality } \\
\text { reported for both } \\
\text { Atlantic Ocean ( } \mathrm{n} \\
=107 ; \text { AVM }= \\
0.9 \% \text { ) and Indian } \\
\text { Ocean }(n=38 ; \\
\text { AVM }=2.6 \%) .\end{array}$ & $\begin{array}{l}\text { Capietto et al. } \\
\text { (2014) }\end{array}$ \\
\hline $\begin{array}{l}\text { Tuna purse seine } \\
\text { fishery }\end{array}$ & Indian Ocean & $\begin{array}{l}\text { AVM and } \\
\text { PRM }\end{array}$ & $\begin{array}{l}\text { Health state of } \\
\text { sharks recorded (4- } \\
\text { point scale); } \\
\text { selected sharks } \\
\text { tagged with PSATs } \\
\text { and released }\end{array}$ & Carcharhinidae & $\begin{array}{l}\text { Carcharhinus falciformis ( } \mathrm{n} \\
=202 \text { ) }\end{array}$ & $69 \%$ & $\begin{array}{l}\text { AVM }=69 \% \text { (but } \\
\text { lower for the } \\
\text { small number that } \\
\text { were entangled in } \\
\text { the meshes } \\
\text { compared to } \\
\text { those that were } \\
\text { brailed). } \\
\text { Of the } 31 \text { sharks } \\
\text { tagged, nine } \\
\text { (29\%) survived for } \\
\text { periods of 6-100 } \\
\text { days with a } \\
\text { further three } \\
\text { (9.7\%) } \\
\text { recaptured, } 11 \\
\text { (35.5\%) died after } \\
\text { periods of 0-35 } \\
\text { days and the } \\
\text { remaining eight } \\
\text { (25.8\%) tags did } \\
\text { not give } \\
\text { conclusive results. } \\
\text { Overall mortality } \\
\text { estimated at } 81 \% \text {. }\end{array}$ & $\begin{array}{l}\text { Poisson et al. } \\
\text { (2014a) }\end{array}$ \\
\hline
\end{tabular}




\begin{tabular}{|c|c|c|c|c|c|c|c|c|}
\hline Fishery & Study area & Approach & Details & Family & Species & AVM & Key findings & Source \\
\hline $\begin{array}{l}\text { Tuna purse seine } \\
\text { fishery }\end{array}$ & $\begin{array}{l}\text { Western } \\
\text { Central Pacific }\end{array}$ & $\begin{array}{l}\text { AVM, } \\
\text { PRM and } \\
\text { blood } \\
\text { sampling }\end{array}$ & $\begin{array}{l}\text { Health state } \\
\text { recorded for sharks } \\
\text { taken at various } \\
\text { stages of the fishing } \\
\text { process. Blood } \\
\text { chemistry and } \\
\text { satellite tags used to } \\
\text { examine post- } \\
\text { release survival }\end{array}$ & Carcharhinidae & $\begin{array}{l}\text { Carcharhinus falciformis ( } \mathrm{n} \\
=295 \text { for condition; } n=26 \\
\text { for satellite tags; } n=87 \text { for } \\
\text { blood chemistry) }\end{array}$ & $0-75.9 \%$ & $\begin{array}{l}\text { AVM was } 0 \% \\
\text { (free-swimming } \\
\text { and encircled } \\
\text { sharks), } 8.3 \% \\
\text { (entangled } \\
\text { sharks), } 51.9 \% \\
\text { (sharks in the first } \\
\text { brail) and } 75.9 \% \\
\text { (subsequent } \\
\text { brails). Total } \\
\text { mortality rate } \\
\text { estimated at } \\
84.2 \%\end{array}$ & $\begin{array}{l}\text { Hutchinson et } \\
\text { al. (2015) }\end{array}$ \\
\hline $\begin{array}{l}\text { Tuna purse seine } \\
\text { fishery. Work } \\
\text { undertaken on } \\
\text { commercial fishing } \\
\text { vessel, fishing } \\
\text { operations of } 1-2 \mathrm{~h} \\
\text { and catch brailed on } \\
\text { board }\end{array}$ & $\begin{array}{l}\text { Eastern Pacific } \\
\text { Ocean }\end{array}$ & $\begin{array}{l}\text { AVM and } \\
\text { PRM }\end{array}$ & $\begin{array}{l}\text { Vitality (1-5 scale) } \\
\text { and AVM data } \\
\text { recorded; PRM } \\
\text { assessed with PSATs }\end{array}$ & $\begin{array}{l}\text { Lamnidae } \\
\text { Carcharhinidae }\end{array}$ & $\begin{array}{l}\text { Isurus oxyrinchus }(\mathrm{n}=1) \\
\text { Carcharhinus falciformis ( } \mathrm{n} \\
=53 \text { ) }\end{array}$ & $\begin{array}{r}- \\
58.5 \%\end{array}$ & $\begin{array}{l}\text { Single fish in } \\
\text { moderate } \\
\text { condition } \\
35.8 \% \text { in fair/poor } \\
\text { condition and } \\
5.7 \% \text { in } \\
\text { excellent/good } \\
\text { condition. Studies } \\
\text { with PSATs } \\
\text { indicated that } \\
\text { sharks in } \\
\text { excellent/good } \\
\text { condition ( } n=2) \\
\text { survived, sharks in } \\
\text { fair condition ( } n= \\
5) \text { showed } 40 \% \\
\text { survival, all sharks } \\
\text { in poor condition } \\
(n=6) \text { showed } \\
\text { post-release } \\
\text { mortality. }\end{array}$ & $\begin{array}{l}\text { Eddy et al. } \\
\text { (2016) }\end{array}$ \\
\hline
\end{tabular}




\begin{tabular}{|c|c|c|c|c|c|c|c|c|}
\hline Fishery & Study area & Approach & Details & Family & Species & AVM & Key findings & Source \\
\hline & & & & Sphyrnidae & Sphyrna spp. $(\mathrm{n}=6)$ & $(0 \%)$ & $\begin{array}{l}\text { Small sample size; } \\
50 \% \text { in } \\
\text { excellent/good } \\
\text { condition; } 50 \% \text { in } \\
\text { fair/poor } \\
\text { condition. Three } \\
\text { specimens were } \\
\text { tagged with } \\
\text { PSATs, showing } \\
100 \% \text { post-release } \\
\text { mortality }\end{array}$ & \\
\hline $\begin{array}{l}\text { Commercial purse } \\
\text { seine fishery for } \\
\text { skipjack tuna }\end{array}$ & New Zealand & PRM & $\begin{array}{l}\text { Pop-up archival } \\
\text { transmitting tags } \\
\text { attached to } \\
\text { commercially } \\
\text { caught fish }\end{array}$ & Mobulidae & Mobula japanica $(\mathrm{n}=9)$ & - & $\begin{array}{l}\text { Seven of the nine } \\
\text { tags provided } \\
\text { data. Three rays } \\
\text { (that had all been } \\
\text { brailed on board) } \\
\text { survived for } \\
\text { periods of } 30-82 \\
\text { days. Four rays } \\
\text { (that had all been } \\
\text { entangled in the } \\
\text { netting and } \\
\text { hauled aboard) } \\
\text { died 1-4 days } \\
\text { after release. }\end{array}$ & $\begin{array}{l}\text { Francis \& Jones } \\
\text { (2016) }\end{array}$ \\
\hline \multicolumn{9}{|c|}{ RECREATIONAL FISHERIES } \\
\hline Recreational gears & Bahamas & PRM & $\begin{array}{l}\text { Sharks caught in } \\
\text { shallow water by } \\
\text { rod and line. } \\
\text { Captured fish kept } \\
\text { fully or partially } \\
\text { submerged. Blood } \\
\text { sampling } \\
\text { undertaken and site } \\
\text { of hooking } \\
\text { recorded. Visual } \\
\text { floats attached and } \\
\text { post-release survival } \\
\text { assessed over } 15 \\
\text { minutes. }\end{array}$ & Carcharhinidae & $\begin{array}{l}\text { Negaprion brevirostris }(\mathrm{n}= \\
32 \text { ) }\end{array}$ & - & $\begin{array}{l}\text { Post-release } \\
\text { mortality } \\
\text { (monitored for } \\
0.25 \text { h post- } \\
\text { release) of } 12.5 \% .\end{array}$ & $\begin{array}{l}\text { Danylchuk et al } \\
\text { (2014) }\end{array}$ \\
\hline
\end{tabular}




\begin{tabular}{|c|c|c|c|c|c|c|c|c|}
\hline Fishery & Study area & Approach & Details & Family & Species & AVM & Key findings & Source \\
\hline $\begin{array}{l}\text { Recreational gears } \\
\text { (either circle or J- } \\
\text { hooks; fight times of } \\
1-513 \text { mins, but } \\
\text { most samples were } \\
\text { for fight times } \leq 1 \mathrm{~h} \text { ) }\end{array}$ & $\begin{array}{l}\text { Southeast } \\
\text { Australia }\end{array}$ & $\begin{array}{l}\text { AVM and } \\
\text { PRM }\end{array}$ & $\begin{array}{l}\text { Catch condition } \\
\text { recorded, and } \\
\text { survivorship Pop-up } \\
\text { Archival } \\
\text { Transmitting (sPAT) } \\
\text { tags deployed. }\end{array}$ & Lamnidae & Isurus oxyrinchus & $0 \%$ & $\begin{array}{l}\text { No AVM }(\mathrm{n}=33) \text {, } \\
\text { with } 84.8 \%, 6.1 \% \\
\text { and } 9.1 \% \text { in good, } \\
\text { average and poor } \\
\text { condition, } \\
\text { respectively. From } \\
\text { specimens tagged } \\
\text { with sPAT tags ( } \mathrm{n} \\
=30 \text { ), post- } \\
\text { release mortality } \\
\text { was } 10 \%\end{array}$ & $\begin{array}{l}\text { French et al. } \\
(2015)\end{array}$ \\
\hline Recreational gears & California & $\begin{array}{l}\text { AVM and } \\
\text { PRM }\end{array}$ & $\begin{array}{l}\text { Satellite tagging of } \\
\text { sharks that were } \\
\text { hooked by the } \\
\text { mouth }(n=7) \text { or } \\
\text { caudal } f i n(n=9)\end{array}$ & Alopiidae & Alopias vulpinus & $0 \%$ & $\begin{array}{l}\text { Specimens } \\
\text { hooked by the } \\
\text { mouth (125-187 } \\
\mathrm{cm} \mathrm{L}_{\mathrm{F}} \text {; fight time = } \\
9-25 \text { mins) all } \\
\text { survived release. } \\
\text { Nearly } 78 \% \text { of } \\
\text { specimens } \\
\text { hooked by the } \\
\text { caudal fin (111- } \\
175 \mathrm{~cm} \mathrm{~L}_{\mathrm{F}} \text {; fight } \\
\text { time }=10-25 \\
\text { mins) died. }\end{array}$ & $\begin{array}{l}\text { Sepulveda et al } \\
\text { (2015) }\end{array}$ \\
\hline
\end{tabular}

